\title{
Evaluation of the START Programme and the Wittgenstein Award
}

Final report

For the Austrian Science Fund (FWF), Vienna

Sarah Seus, Eva Heckl, Susanne Bührer

with the participation of Niclas Meyer, Sonia Gruber, Tobias Burst, Christina Schmedes and Barbara Sinnemann

DOI: $10.5281 /$ zenodo.50610

Karlsruhe, Wien, April 2016 



\section{Contents}

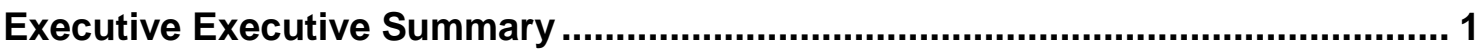

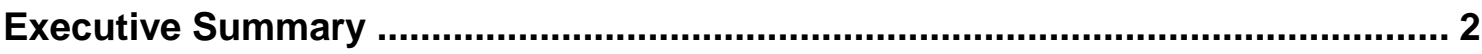

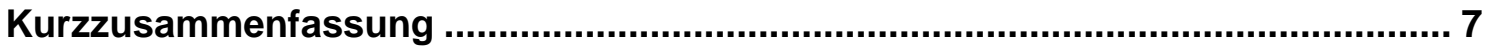

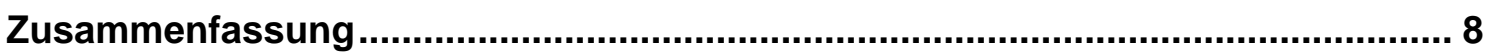

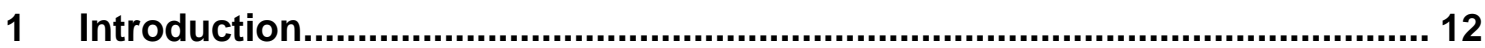

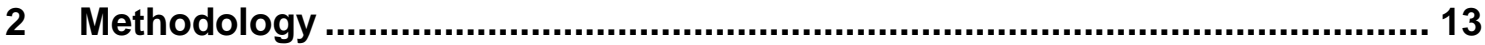

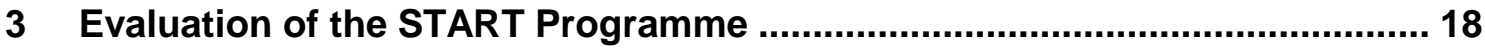

3.1 Internal Positioning of the START Programme in the FWF Funding Portfolio .................................................................... 19

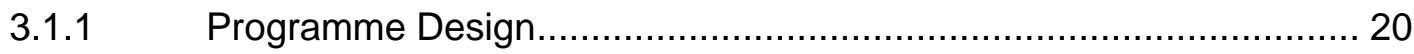

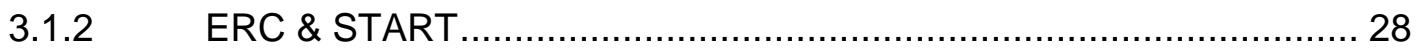

3.2 Programmme Management ..................................................... 32

3.2.1 Target Group and Selection Process ........................................... 33

3.2.2 Administrative Requirements and Processes............................... 41

Outputs, Outcomes and Impacts ................................................ 43

3.3.1 Direct Effects on the START Grantees ........................................ 43

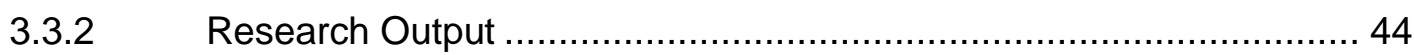

3.3.3 Outputs beyond Scientific Publications ......................................... 51

3.3.4 Career Development of the START Grantees................................. 55

3.3.5 Promotion of Young Researchers ............................................... 64

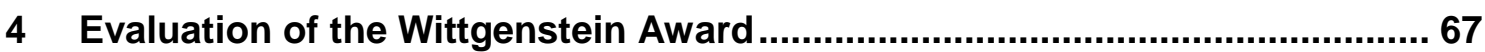

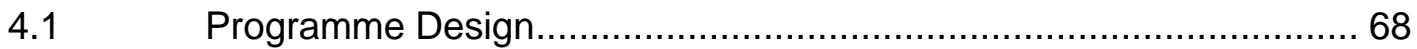

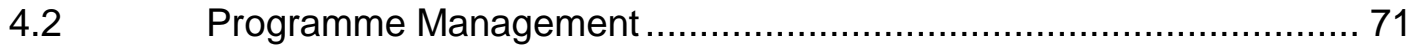


4.3 Outputs, Outcomes and Impacts ............................................... 73

4.3.1 Impact on the Awardees' Research Career .................................. 77

4.3.2 Promotion of Young Researchers ................................................ 77

4.3.3 The Wittgenstein Award and Public Awareness .............................. 80

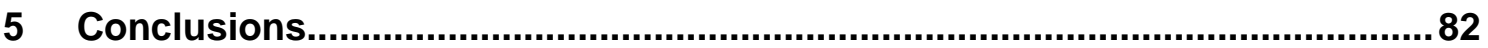

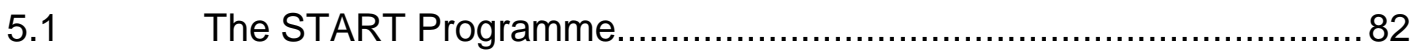

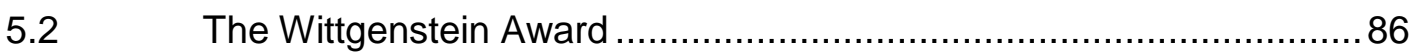

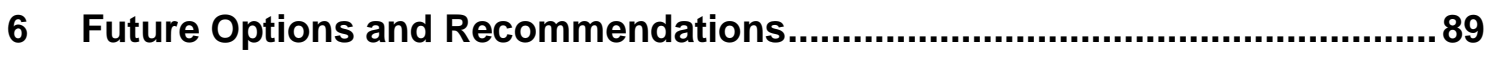

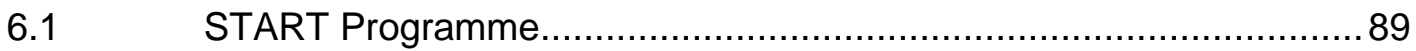

6.1.1 Future Options of the START Programme ................................. 89

6.1.2 Core Recommendations for the START Programme.........................91

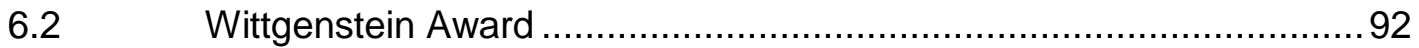

6.2.1 Future Options of the Wittgenstein Award ...................................... 92

6.2.2 Core Recommendations for the Wittgenstein Award .........................94

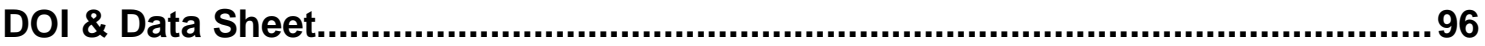

The Annexes can be found in a separate volume. 


\section{Figures}

Figure 1: $\quad$ Motives for a START application: aspects related to the research group (START grantees)

Figure 2: $\quad$ Motives for a START application: aspects related to research management (START grantees)

Figure 3: $\quad$ Motives for a START application: aspects related to career development (START grantees)

Figure 4:

START as an instrument for promoting career development (control and comparison group)

Figure 5:

Visibility of the START Programme 24

Figure 6:

Impact diagram of the START Programme

Figure 7:

Assessment of appropriateness of funding opportunities during the post-doc period (START grantees)

Figure 8:

The START Programme as an instrument for preparing for an ERC-Starting grant application (Control and comparison group)

Figure 9: $\quad$ Obligation to apply for START \& ERC in parallel (START grantees after 2006)

Figure 10: $\quad$ Comparing the START Programme to the ERC Starting grants

Figure 11: $\quad$ Administrative burden related to a double application START/ERC (START grantees after 2006)....

Figure 12: $\quad$ Rating on different aspects of FWF's assistance (START grantees)

Figure 13: $\quad$ Degree to which initial expectations towards the START Programme were met (START grantees).

Figure 14:

Average number of publications per year 45

Figure 15:

Average citation rate. 45

Figure 16:

Co-publications, collaborating organisations and countries 46

Figure 17: $\quad$ Effects of the START project on the performance in the area of research (START grantees)..... 48

Figure 18: $\quad$ Possibility to conduct planned research without START funding (Start grantee and comparison group) 
Figure 19: $\quad$ Funding used by comparison group to realise research project orignally planned as a START project (comparison group) 50

Figure 20: Use of START project results (START grantees) .52

Figure 21: $\quad$ Effects of the START project on the performance in the area of research management (START grantees) .53

Figure 22: $\quad$ Assessment of the visibility and reputation of the START Programme 54

Figure 23:

Sector of employment of surveyed researchers .56

Figure 24:

Highest position in the research system reached to date* 58

Figure 25: Permanent vs. temporary work contract (START grantees) .59

Figure 26: Effects of the START/ERC grant on the career (START grantees and comparison group).

Figure 27: $\quad$ Effect of the START Programme/ERC grant on the negotiation position towards the host institution (START/ERC grantees)

Figure 28: $\quad$ Career prospects of the START group members (START grantees)

\section{Tables}

Table 1:

Participation in the online surveys .15

Table 2:

Gender distribution of START candidates and grantees. 36

Table 3:

Regional distribution of START candidates and grantees. 38

Table 4:

Disciplinary distribution of START candidates and grantees 39

Table 5:

Total number and average of supervised theses in START research groups.

Table 6: $\quad$ Total number of supervised theses in Wittgenstein research groups

\section{Boxes}

Box 1: The management of the START Programme seen by ERC grantees 


\section{Executive Executive Summary}

In October 2014, the Fraunhofer ISI and KMU Forschung Austria were commissioned by the FWF to evaluate the START Programme and the Wittgenstein Award, both created in 1996 and managed by the FWF. The evaluation used a mixed-method approach with quantitative and qualitative data and analytical methods. The core methods used were a bibliometric analysis of research outputs of the START grantees in comparison to a control group; online surveys of the START grantees, the control group and unsuccessful applicants; interviews and case studies; a literature research and analysis of monitoring data. A validation workshop complemented the approach.

The START Programme and the Wittgenstein Award both show unique features within the Austrian funding landscape: The START Programme is the only programme in Austria which provides a kind of "starter kit" for a research career. And the Wittgenstein Award is the only FWF programme which follows the principle "fund people, not projects".

The START Programme has a considerable positive effect on the scientific performance of START grantees who perform better than the control group across all of the bibliometric indicators that were taken into consideration. There is also evidence that the START Programme enables new and unconventional research fields to be tested. Additionally, the START Programme contributes strongly to the career development of START grantees. All START grantees stay in the research system, the majority in an Austrian institution. A START project group is also an effective instrument to enhance the qualifications of young researchers.

The Wittgenstein Award has undoubtedly facilitated the pursuit of unconventional and creative research streams and high risk projects, an increase in the scientific performance and enhanced visibility of Austrian research and researchers. The research freedom has been used to develop new methods, conduct interdisciplinary research and focus on new research questions. The exploration of new avenues of research is evidenced by the many successful applications for further funding and the publication analysis. These kinds of projects would not have been funded by other programmes. The Wittgenstein groups have been able to expand and maintain their leading role in cutting-edge research and represent a favourable and stimulating environment for young researchers. Both programmes are very well managed with reasonable administrative requirements.

Based on the numerous positive impacts on the Austrian research system, there are no reservations in recommending a continuation of both the START Programme and the Wittgenstein Award. 


\section{Executive Summary}

\section{Background}

In October 2014, the Fraunhofer ISI and KMU Forschung Austria were commissioned by the FWF to evaluate the START Programme and the Wittgenstein Award, both created in 1996 and managed by the FWF. Both programmes aim at funding excellent research in Austria, and provide researchers with financial resources for a timeframe of up to six years, allowing them to perform research freely and flexibly. While the START programme targets excellent young researchers not yet fully established in the Austrian research system's institution, the Wittgenstein Award is for outstanding past scientific performance and is the highest recognition for researchers in Austria. Each year, these programmes provide funding for to up to nine START grantees and one or two Wittgenstein awardee(s).

\section{Methods}

The evaluation combined different data sources as well as qualitative and quantitative analytical methods. These methods included desk review of documents, analysis of monitoring data, face-to-face interviews with the FWF, the responsible Ministry (BMWFW) and members of the START/Wittgenstein jury (eight interviews). Interviews were also conducted with seven Wittgenstein Award winners, and eight case studies were made of START projects that combined the views of START grantees, representatives of host institutions of START projects, and START project group members (23 interviews in total). Online surveys were done of START grantees (114 questionnaires sent, 94 responses), and a control group was generated using the bibliometric database Scopus (307 questionnaires sent, 75 responses). A comparison group was also set up comprising unsuccessful applicants to the START Programme (49 questionnaires sent, 25 responses). Bibliometric analysis was made of the research output of the START grantees and the control group as well as a bibliometric analysis of the research fields of Wittgenstein awardees. Finally, a validation workshop was held with START and Wittgenstein grantees as well as representatives from universities and the FWF.

\section{The START Programme}

The START Programme addresses all the relevant elements needed to promote research excellence and help develop the careers of young researchers. This is done for START grantees as well as the group members of a START project. The level and duration of funding are adequate to achieve these goals. 
The selection process of START grantees is appropriate, fair and transparent. The programme's sole selection criterion is 'research excellence'. The bibliometric analysis shows that the START Programme selects the most qualified researchers. However, there is a bias with regard to applicants' discipline and regional origin. The distribution pattern reveals certain "hotspots" which receive above-average START funding, i.e. START has contributed to shaping regional and disciplinary research centres of research excellence.

The START Programme is very well managed with reasonable administrative requirements, especially in comparison to the grants of the European Research Council (ERC).

The START Programme targets researchers in a decisive career phase when excellent researchers may be tempted to leave the Austrian research system due to a lack of long-term perspectives. The START Programme is the only programme in Austria which provides a sort of "starter kit" for a research career. The scientific performance outcomes of START projects suggest that providing a substantial amount of funding spread over a long period of time is a necessary element to obtain significant results in basic research and push the frontiers of knowledge. The high prestige of the grant is furthermore conducive to the career development of the grantees in the Austrian research system. By combining the funding of excellent research with career development elements, the START Programme is unique in Austria and has an important role in the FWF funding portfolio. The only comparable funding instrument available to researchers in Austria is the ERC Starting grant.

Even though it is not as well known internationally as the ERC Starting grant, the START Programme is seen as a valuable and equivalent alternative to ERC funds by the research community in Austria. The double application obligation has contributed to the visibility of the ERC in Austria and Austrian researchers are very well represented within the group of successful ERC grantees in comparison with other European countries. The main argument for the coexistence of these two programmes is the exceptional resources both provide to young researchers in a decisive career phase, and therefore the possibility to provide more researchers with such an exceptional kind of funding. As these kinds of grants are scarce and competition for them is intense, the double application requested by the FWF since the introduction of the ERC Starting grant is accepted by the majority of researchers.

The START Programme has considerable positive effects on the scientific performance of START grantees, during and also after the end of the funding. START grantees perform better than the control group for all indicators that were taken into consid- 
eration. There is evidence that the START Programme allows new and unconventional research fields to be tested. Research results have also been used for further project acquisition and the establishment of cooperation, for teaching purposes and, to a lesser extent, for commercial purposes. Its excellent reputation means START grantees and the START Programme are very visible in the research community in Austria, and to some extent also in the international research community.

The START Programme contributes to the career development of the START grantees. All START grantees stay within the research system. The majority remains in an Austrian institution, with a third being employed by a foreign research organisation after the end of the START project. Almost $80 \%$ of START grantees hold a professorship. However, the control group follows similar career paths as the START grantees. For START grantees, a START grant is often seen as the decisive element for remaining in Austria. A START grant also opens the door to negotiating for a permanent position in the research system. Today, the majority of research institutions offer START grantees a tenure track position as they see START as an asset to the institution.

A START project group is an effective instrument to enhance the qualifications of young researchers. These groups provide young researchers with access to top level research and the relevant research community. START grantees have supervised numerous master's and PhD theses. The international character of the group is equally well appreciated as is the good availability of funding for mobility and exchanges within the research community.

Based on the aforementioned conclusions, we have no reservations in recommending a continuation of the START Programme in its present form.

\section{The Wittgenstein Award}

The Wittgenstein Award stimulates future research productivity by giving sufficient resources to outstanding researchers, allowing freedom and flexibility in their research. Furthermore, the funding which is mostly spent in research groups goes to promising young researchers. The Wittgenstein Award is the only programme of the FWF which follows the principle "fund people, not projects" and which allows blue sky research. As the most competitive and high end programme, it receives media attention and certain publicity. By combining these elements, it is unique in Austria and can contribute to strengthening the Austrian research system.

The nomination process is a particularity of the Wittgenstein Award and seems appropriate to the nature of this award also due to a lack of alternatives. Although the group of people who is entitled to nominate candidates is seen as adequate, it is pro- 
posed to reduce this group in order to reduce the number of nominations. An international jury is in charge of selecting candidates on the basis of peer reviews. As outstanding researchers are assessed, the qualifications of the peer reviewers and jury members are crucial for the acceptance and legitimisation of their verdict. Thus, they have to be on a similar level of expertise as the candidates.

The programme management and the formal requirements (short yearly reports, final report) mirror the flexibility and freedom of the programme. Compared to other funding organisations, the FWF seems very non-bureaucratic.

The Wittgenstein funds have undoubtedly facilitated the pursuit of unconventional and creative research streams and high risk projects, an increase in scientific performance and in enhancing the visibility of Austrian research. The freedom of research has been used to develop new methods or adapt methods to other research fields, to conduct interdisciplinary research, or focus on new aspects and new research questions. The exploration of new avenues of research is evidenced by the many successful applications for further funding and the publication analysis. These kinds of projects would not have been funded in the framework of other programmes.

The increased research productivity of the Wittgenstein groups is witnessed by numerous high level publications and the fact that the majority of awardees publish more during the award phase than before. With the FWF funding, the Wittgenstein groups have been able to expand their leading role in cutting-edge research.

The awardees' research groups are perceived as leaders in their respective fields. This contributes to increased visibility and enhanced international reputation of the awardees and their research (groups) and strengthens Austria as a location for research. In this context, many co-operations have been established and intensified. The Wittgenstein Award increases the visibility and reputation of the award-winner mainly within the research community at national and international level. The Award also has a very positive impact on the already very advanced careers of the award-winners. This is evidenced by the acquisition of ERC Advanced Grants, the Membership in the Austrian Academy of Science and winning other international and national research awards.

A Wittgenstein group offers a favourable and stimulating environment. A substantial part of the funding is typically spent on young researchers that profit from access to top level research and the international research community. Wittgenstein Award winners have supervised numerous master's and PhD theses. The sustainable positive impact on team members is mirrored in their remarkable careers. Many are well established in the research system, hold top jobs at postdoctoral or professor level, and/or are successful in applying for highly competitive grants (e.g. ERC, Marie Curie). 
The Wittgenstein Award seems tailor-made for its target group and adds value to the research system in Austria. Hence, it is recommended to continue the programme 


\section{Kurzzusammenfassung}

Im Oktober 2014 wurden das Fraunhofer ISI und die KMU Forschung Austria vom FWF damit beauftragt, die das START-Programm sowie den Wittgenstein-Preis zu evaluieren. Die Evaluation basierte auf einem Methodenmix bestehend aus einer bibliometrischen Analyse inklusive Kontrollgruppenvergleich, Online-Befragungen mit unterschiedlichen Zielgruppen, Experteninterviews, Fallstudien, Auswertung von Programm- und Monitoring-Daten sowie einem Validierungsworkshop.

Als Ergebnis kann festgehalten werden, dass sowohl START als auch der Wittgenstein-Preis einzigartig in der österreichischen Förder- und Forschungslandschaft sind: Das START-Programm ist das einzige Programm in Österreich, das eine Art "Startpaket" für eine wissenschaftliche Karriere von vielversprechenden NachwuchsforscherInnen bereit hält. Der Wittgenstein-Preis ist die einzige Förderung, die dem Prinzip "Finanziere Menschen, nicht Projekte" folgt.

Das START-Programm erhöht die ohnehin schon hohe wissenschaftliche Leistungsfähigkeit der Geförderten deutlich: Deren Leistungen sind, gemessen an bibliometrischen Indikatoren, signifikant besser als diejenigen der Kontrollgruppe. Es gibt außerdem Hinweise darauf, dass mit Hilfe der START-Förderung neue und unkonventionelle Fragestellungen untersucht werden. Zusätzlich befördert das Programm die Karriereentwicklung der Geförderten: Alle bisher Geförderten sind im Wissenschaftssystem geblieben, darunter die Mehrzahl in einer österreichischen Institution. START ist außerdem ein wirksames Instrument für die Qualifizierung junger ForscherInnen.

Der Wittgenstein-Preis hat zu unkonventionellen und Hochrisiko-Forschungsaktivitäten beigetragen, die wissenschaftliche Leistungsfähigkeit erhöht und die Sichtbarkeit österreichischer Forscherinnen und Forscher, aber auch der Forschung in Österreich, erhöht. Die mit dem Preis verbundenen Freiheiten wurden genutzt, um neue Methoden und Forschungsfragen zu entwickeln und interdisziplinär zu forschen. Die Herausarbeitung neuer Forschungsschwerpunkte fand ihren Niederschlag in zahlreichen erfolgreichen Drittmitteleinwerbungen. Derartige risikoreiche und innovative Vorhaben hätten im Rahmen anderer Programme nicht finanziert werden können. Die WittgensteinGruppen haben ihre führende Rolle in der Spitzenforschung ausgebaut und eine anregende Umgebung für junge ForscherInnen geschaffen.

Aufgrund der zahlreichen positiven Wirkungen für das österreichische Wissenschaftssystem empfehlen wir ohne Einschränkung eine Fortsetzung der beiden Programme. 


\section{Zusammenfassung}

Ausgangslage

Im Oktober 2014 wurden das Fraunhofer ISI und die KMU Forschung Austria vom FWF damit beauftragt, die von inm administrierten Programme START und WittgensteinPreis zu evaluieren. Beide Programme zielen auf die Förderung exzellenter Forschung ab und stellen hierzu eine bis zu sechsjährige Finanzierung zur Verfügung, um den Geförderten die Möglichkeit zu geben, ihre Forschung so frei und flexibel wie möglich durchzuführen. Während sich das START-Programm an junge, exzellente Forscherlnnen richtet, belohnt der Wittgenstein-Preis herausragende vergangene Forschungsleistungen und bildet damit die höchste Anerkennung für Wissenschaftlerlnnen in Österreich. Jedes Jahrs werden bis zu neun START-Nachwuchsgruppenleiterlnnen gefördert und ein bis zwei Wittgenstein-PreisträgerInnen.

\section{Methodisches Vorgehen}

Die Evaluation basierte auf unterschiedlichen Datenquellen sowie quantitativen und qualitativen Analysemethoden. Konkret erfolgte eine Analyse von Programmdokumenten und Monitoring-Daten; Interviews mit RepräsentantInnen des FWF, des verantwortlichen Ministeriums (BMWFW) und Mitgliedern der START/Wittgenstein-Jury (insgesamt acht); Interviews mit sieben Wittgenstein-PreisträgerInnen; acht Fallstudien zu START-Projekten mit insgesamt 23 Interviews (Geförderte, Mitglieder der Arbeitsgruppen, Vertreterlnnen der Hochschule); Online-Surveys mit START-Geförderten (114 Personen kontaktiert, 94 Antworten), mit einer Kontrollgruppe, die mit Hilfe der bibliometrischen Datenbank Scopus generiert wurde (307 Personen angeschrieben, 74 Antworten) sowie mit einer Vergleichsgruppe, die sich aus nicht erfolgreichen STARTAntragstellerInnen zusammengesetzt hat (49 Personen kontaktiert, 25 Antworten). AuBerdem wurde eine bibliometrische Analyse des wissenschaftlichen Outputs der START-Geförderten und einer Kontrollgruppe durchgeführt sowie eine bibliometrische Analyse der Forschungsfelder, in denen die Wittgenstein-PreisträgerInnen arbeiten. Ein Validierungsworkshop mit VertreterInnen der Geförderten, des FWF und von Universitäten hat das Methodenspektrum abgerundet.

\section{The START Programme}

Das START Programm enthält alle notwendigen Elemente, um wissenschaftliche Exzellenz und die Karriereentwicklung junger Forscherinnen und Forscher - der Geförderten selbst wie auch der Mitglieder der Arbeitsgruppen - zu fördern. Sowohl die Höhe als auch die Dauer der Förderung sind angemessen, um die Förderziele zu erreichen. 
Der Auswahlprozess der START-Geförderten entspricht den Programmeigenschaften gut, der Entscheidungsfindungsprozess ist fair und transparent, wobei als Auswahlkriterium die wissenschaftliche Exzellenz maßgeblich ist. Die bibliometrische Analyse zeigt, dass START tatsächlich die herausragendsten Forscherinnen und Forscher auswählt. Die ausschließliche Orientierung an Exzellenz manifestiert sich auch daran, dass die regionale und disziplinäre Verteilung nicht gleichmäßig erfolgt, sondern eine Konzentration auf bestimmte Regionen und Disziplinen in sogenannten "hot spots" zeigt.

Das START-Programm wird sehr gut gemanagt, die administrativen Anforderungen sind, besonders im Vergleich zum ERC, angemessen und zielführend.

Das START-Programm richtet sich an junge Forschende, die sich in einer entscheidenden Karrierephase befinden und angesichts mangelnder Aussichten auf eine unbefristete Anstellung ggf. ins Ausland abwandern könnten. START ist das einzige Programm in Österreich, das eine Art "Startpaket" für die wissenschaftliche Karriere bietet. Die wissenschaftlichen Leistungen und Ergebnisse der geförderten START-Projekte zeigen, dass eine nennenswerte Fördersumme in Kombination mit einer langen Förderdauer eine entscheidende Voraussetzung dafür ist, herausragende Ergebnisse in der Grundlagenforschung bzw. Pionierforschung zu erzielen.

Das hohe Prestige von START fördert die Karriereentwicklung der Geförderten, vor allem im österreichischen Wissenschaftssystem. Durch die Kombination von Exzellenzmit Karriereförderung ist START einzigartig in Österreich und innerhalb des FWFPortfolios. Das einzige vergleichbare Förderinstrument für österreichische Forscherlnnen sind auf europäischer Ebene die ERC Starting Grants. Gleichwohl wird START von der österreichischen Forschungsszene als wertvolle und gleichwertige Alternative zu ERC angesehen. Die Verpflichtung zur doppelten Antragstellung hat dabei einerseits zu einer erhöhten Sichtbarkeit des ERC in Österreich geführt, andererseits aber auch zu einer guten Repräsentanz österreichischer Forscherinnen und Forscher unter den erfolgreichen ERC-Antragstellern. Das Hauptargument für die gleichzeitige Existenz beider Programme liegt darin, dass beide erhebliche finanzielle Ressourcen für die Forschung von herausragenden jungen WissenschaftlerInnen, die sich in einer wichtigen Karrierephase befinden, zur Verfügung stellen und damit die Möglichkeit besteht, mehr Personen in dieser Weise zu fördern, als dies alleine mit nationalen Mitteln möglich wäre.

Die Evaluation konnte zeigen, dass das START Programm beträchtliche positive Wirkungen auf die wissenschaftliche Leistung der Geförderten hat, und zwar sowohl während als auch nach der Förderung: Die Geförderten sind hinsichtlich aller erhobenen 
bibliometrischen Indikatoren besser als die Kontrollgruppe. Es gibt außerdem Hinweise darauf, dass mit Hilfe der START-Förderung neue und unkonventionelle Fragestellungen untersucht werden. Die Forschungsergebnisse wurden außerdem für weitere Drittmitteleinwerbungen, den Auf- und Ausbau wissenschaftlicher Kooperationen, für die Lehre und stellenweise auch für die kommerzielle Verwertung genutzt.

Zusätzlich unterstützt das Programm die Karriereentwicklung der Geförderten: Alle bisher Geförderten sind im Wissenschaftssystem geblieben, die Mehrzahl in einer österreichischen Institution. Etwa 80\% der Geförderten haben eine Professur inne. Dabei ist darauf hinzuweisen, dass auch die Mitglieder der Kontrollgruppe ähnlich positive Karriereverläufe aufweisen. Dennoch ist für die Geförderten START ein maßgeblicher Grund dafür, in Österreich zu verbleiben, zumal START eine gute Ausgangbasis für die Verhandlungen um eine unbefristete Stelle darstellt. Mittlerweile bietet die Mehrzahl der aufnehmenden Einrichtungen ihren STARTern eine tenure track Position an, da dies auch deren eigene Reputation steigert.

START ist außerdem ein wirksames Instrument für die Qualifizierung junger ForscherInnen. Sie bieten den in START-Projekte eingebundenen NachwuchswissenschaftlerInnen ein exzellentes wissenschaftliches Umfeld und Zugang zur (internationalen) wissenschaftlichen Community. Die hohe Flexibilität der START-Förderung lässt es zu, dass beispielsweise auch internationale Mobilität gefördert werden kann. Als konkretes Ergebnis der START-Gruppen sind eine Vielzahl an betreuten Master- und Doktorarbeiten zu nennen.

Durch die hohe Reputation von START sind sowohl die Geförderten selbst als auch das Programm sehr sichtbar in der wissenschaftlichen Community Österreichs, zum Teil auch in der internationalen.

Aufgrund der zahlreichen positiven Wirkungen für das österreichische Wissenschaftssystem empfehlen wir ohne Einschränkung eine Fortsetzung des Programms.

\section{The Wittgenstein Award}

Der Wittgenstein-Preis stimuliert zukünftige Forschung, indem er herausragenden Forscherlnnen die Mittel gibt, ihre Forschung so frei und flexibel wie möglich durchzuführen. Da die Förderung größtenteils für Forschungsgruppen ausgegeben wird, werden durch den Preis auch junge AkademikerInnen unterstützt. Der Wittgenstein-Preis ist das einzige FWF-Programm, das dem Prinzip "fördere Menschen, nicht Projekte" folgt und das demzufolge "blue sky research" ermöglicht. Der Wittgenstein-Preis genießt aufgrund seiner Einzigartigkeit in Österreich eine hohe Medienaufmerksamkeit und kann damit das österreichische Wissenschaftssystem stärken. 
Wittgenstein-PreisträgerInnen werden nominiert. Dieser Prozess erscheint aufgrund der Natur einer solchen Auszeichnung angemessen, besonders auch im Hinblick darauf, dass wenige Alternativen existieren. Gleichwohl kann darüber nachgedacht werden, ob die Gruppe der Personen, die eine/-n zukünftige/-n PreisträgerIn vorschlagen dürfen, reduziert wird, um die Anzahl der Nominierungen in überschaubarer Anzahl zu halten. Bei der international besetzten Jury, die am Ende über die Auswahl entscheidet, achtet man auf "Augenhöhe" zu den Nominierten, d.h. eine vergleichbare wissenschaftliche Exzellenz.

Das Programmmanagement und die formalen Anforderungen (kurze jährliche Berichte, ein Endbericht) spiegeln die Flexibilität und Freiheit des Preises wieder. Verglichen mit anderen Förderorganisationen ist der FWF in dieser Hinsicht sehr unbürokratisch.

Der Wittgenstein-Preis hat zweifellos zu unkonventionellen und Hochrisiko-Forschungsaktivitäten beigetragen, die wissenschaftliche Leistungsfähigkeit und die Sichtbarkeit österreichischer Forscherinnen und Forscher, aber auch der Forschung in Österreich, erhöht. Dies geschah nicht zuletzt durch einen Ausbau der internationalen Vernetzung. Die mit dem Preis verbundenen Freiheiten wurden genutzt, um neue Methoden und Forschungsfragen zu entwickeln und interdisziplinär zu forschen. Die Herausarbeitung neuer Forschungsschwerpunkte fand ihren Niederschlag in zahlreichen erfolgreichen Drittmitteleinwerbungen. Die wissenschaftliche Produktivität der Wittgenstein-Gruppen zeigt sich in zahlreichen Publikationen in exzellenten Journalen sowie daran, dass die PreisträgerInnen nach ihrer Auszeichnung (noch) mehr publizieren als vorher. Außerdem konnten PreisträgerInnen ERC Advanced Grants einwerben, haben weitere nationale und internationale Forschungspreise gewonnen und sind teilweise Mitglied in der Österreichischen Akademie der Wissenschaften.

Risikoreiche und innovative Vorhaben, wie sie die PreisträgerInnen mit ihren Gruppen durchführen, hätten im Rahmen anderer Programme nicht finanziert werden können. Die Wittgenstein-Gruppen haben ihre führende Rolle in der Spitzenforschung ausgebaut und eine anregende Umgebung für junge Forscherlnnen geschaffen. Letztere profitieren durch die Möglichkeit, in einem international ausgerichteten herausragenden Wissenschaftsumfeld tätig sein zu können, aus dem heraus zahlreiche Master- und Doktorarbeiten entstanden sind. Außerdem haben einige der MitarbeiterInnen der Wittgenstein-Gruppen beachtliche wissenschaftliche Karrieren eingeschlagen, in Form von Professuren oder post-doc-Stellen an renommierten Forschungsstätten. Außerdem haben zahlreiche MitarbeiterInnen ERC- bzw. Marie Curie Grants eingeworben.

Der Wittgenstein-Preis erscheint vor diesem Hintergrund maßgeschneidert für die Zielgruppe zu sein und einen hohen Mehrwert für das österreichische Wissenschaftssystem zu gewährleisten. Daher empfehlen wir eine Fortsetzung der Förderung. 


\section{$1 \quad$ Introduction}

In October 2014, the Fraunhofer ISI and KMU Austria were commissioned by the FWF to evaluate the START Programme and the Wittgenstein Award with the objective of informing policy makers and interested stakeholders of the performance and achievements of the two programmes and to provide the FWF with the information it requires to decide on the future of these programmes and their design. More specifically, the objectives of this study were threefold:

- To assess the objectives, design and management of the START Programme and the 'Wittgenstein' Award and to provide information for an assessment on the FWF's funding portfolio for post-doctoral research;

- To assess the outputs, outcomes and impacts of the two programmes;

- To provide the FWF with information and recommendations on how to further develop these two programmes.

The two programmes under evaluation were jointly created in 1996 and share the overall objective of providing selected individual researchers with financial security for a timeframe of up to six years and thereby allowing them to perform their research freely and flexibly. Each year, up to nine START projects and one to two Wittgenstein awards are granted to top-level researchers in Austria. Due to a degree of congruence of their objectives and similar implementation characteristics, the START Programme and the Wittgenstein Award are often named together, as also in this evaluation assignment. However, both programmes address different target groups and have developed in distinct directions in there close to 20 years of existence. Therefore, this evaluation report discusses the design, management and results of the two initiatives in two separate chapters.

The following report therefore consists of two independent parts: the assessment of the START Programme can be found in chapter 3; the assessment of the Wittgenstein Award in chapter 4. A short description of the methodological approaches for both assessments can be found in chapter 2 . Conclusions can be found in chapter 5 . The Annex provides detailed information on the methods and data sources, as well as the evidence provided by this report. The Annex can be found in a separate volume.

The evaluation was carried out between October 2014 and April 2016. 


\section{Methodology}

With the aim of triangulating the evidence, the evaluation questions have been answered by combining different data sources as well as qualitative and quantitative analytical methods, wherever possible and deemed meaningful. These methods were:

- Desk review of documents;

- Analysis of monitoring data;

- Face to face Interviews with representatives of the FWF, the responsible Ministry (BMWFW) and members of the START/Wittgenstein-Jury;

- Interviews with Wittgenstein Award winners;

- Online surveys of
a) START grantees,
b) a generated control group,
C) non-successful applicants for the START Programme (comparison group);

- Bibliometric analysis of the research output of the START grantees and the control group;

- Bibliometric analysis of the research fields of Wittgenstein awardees;

- Case studies combining views by START grantees, representatives of host institutions of START projects, and START projects group members;

- Validation workshop.

This chapter describes the main elements of the methodological approach and empirical basis of the report in order to assure an appropriate understanding of the provided results and the subsequent conclusions.

More details on the data collection and analysis methods used as well as further analysis of the data can be found in the annexes (see separate volume to the main report).

\section{Desk review of documents and analysis of FWF monitoring data}

The evaluation team systematically analysed the existing literature on the research funding system in Austria and specific information on the START Programme/Wittgenstein Award and the FWF funding portfolio. Additionally, specific documentary resources on the START Programme and the Wittgenstein Award have been made available by the FWF, such as internal reports (project proposals, mid-term 
and final project reports), as well as quantitative data available in the monitoring system of the FWF.

\section{Online surveys (only START Programme)}

Overall, three different target groups were surveyed in the course of this evaluation:

- The START grantees: based on the FWF database and contact details, all beneficiaries who have received a grant since 1996 were contacted by email and asked to participate in the survey. Overall these were 114 individuals.

- The control group (CG): This group was generated via the bibliometric database Scopus. For each START grantee three "twins" were generated and randomly selected from the Scopus database. Twins have been defined as researchers who show similar structural features to the START grantee (such as discipline, scientific age1, gender, affiliation to an Austrian research institution2) and similar scientific performance to the START grantees at the time of the beginning of the START funding. In order to have a sufficiently high response rate and have a similar absolute amount of responses as in the group of the START grantees, the control group was created three times bigger than the group of the START grantees. 3 In total 307 researchers could be identified by matching the criteria of a control group. From the 307 control group members, 23 individuals could not be reached, due to invalid email addresses etc.; four individuals were not willing to participate.

- A comparison group: non-successful applicants START Programme (candidates to START = CS): Since 2006 the application process to the START Programme has comprised a hearing before a Jury. The applicants who are invited to the hearing have already passed a rigorous selection process in which their scientific performance has been ranked as one of the best in their disciplines. These non-successful applicants can therefore be seen as a comparison group showing many similar features to the START grantees. Since 2006, there have been 57 applications; as some

1 The publication age refers to the time since the first time a researcher appeared in the database with a first publication. This was used as a proxy for the researchers' real age.

2 As the START Programme targets mainly researchers who have been previously affiliated to an Austrian research institution, only researchers with at least five publications in five years have been selected. This approach also aimed at targeting persons who are familiar with the Austrian research landscape and funding system.

3 It was not possible to generate three twins for all START grantees, as for some START grantees no researchers who fulfilled all criteria in a sufficient manner could be identified in the Scopus database. In total, for 108 START awardees at least one twin could be found. A detailed discussion on the generation of the control group can be found in the Annex. 
researchers have applied more than one time to the START Programme, the questionnaire has been sent to 49 individuals.

Each of the three groups received a different questionnaire. The following table gives an overview on the participation in the online questionnaires.

Table 1: $\quad$ Participation in the online surveys

\begin{tabular}{|l|c|c|c|}
\hline Surveyed group & $\begin{array}{c}\text { No of questionnaire } \\
\text { sent }\end{array}$ & $\begin{array}{c}\text { No of } \\
\text { responses }\end{array}$ & Response rate \\
\hline START grantees & 114 & 94 & $82 \%$ \\
\hline Control group (CG) & $\begin{array}{c}307 \\
\text { from which 27 non-valid } \\
\text { email addresses }\end{array}$ & 75 & $24 \%$ \\
\hline Comparison group (CS) & 49 & 25 & $51 \%$ \\
\hline
\end{tabular}

The surveys were online between March and April 2015. The questionnaires can be found in the Annex.

\section{Research output analysis based on bibliometric database}

The study team conducted a bibliometric analysis to assess the scientific performance of the START grantees. In order to substantiate the results, the control group was compared to the group of START grantees, but unlike for the online survey, only one twin, called the "main twin" was used for the bibliometric analysis. This was the twin that best matched the characteristics of its corresponding START grantee. (For the generation of the twins, see in Annex). In total, 112 START grantees have been compared to 108 twins.

The scientific performance has been calculated using five indicators as proxy, namely:

- number of publications,

- citation rate,

- number of publication written with co-authors,

- number of organisations per co-publication,

- number of countries with which co-publications are written.

In order to describe the change in the scientific performance over time and allow statements on the immediate and medium term effects of the START funding, the above-mentioned indicators were measured for three different timeframes, corresponding to different periods in the research life of the START grantee. The indicators for the control group twin were calculated following the specific timeframe of its corresponding START grantee. 
In order to take into account the time lag between the generation of research outputs and their publication in scientific journals, the period of analysis did not correspond completely to the funding period of the START Programme, but was adjusted for the time lag.

The three periods are defined as follows, each of them including on average 5 years:

- Before the START funding period: this period is defined as three years before the beginning of the START funding until after the second year of funding. ( $n=103$ START grantees; 102 control group)

- Period during which START funding has been received: this period starts in the third year of the START funding until one year after the end of the funding period. ( $n=51$ START grantees; 54 control group)

- After the START funding period: this is defined as the period from two to seven years after having received the START funding. ( $n=38$ START grantees; 36 control group)

\section{Bibliometric analysis of research fields}

The aim of this analysis was to visualize the research fields in which each Wittgenstein awardee published between 1996 (start of the Scopus database) and 2014. An individual diagram has been created for each awardee showing the percentages of publications in the different research fields for each year. This diagram also shows the absolute yearly number of publication and shows also the period in which the Wittgenstein awardee received the award.

These descriptive diagrams visualize the publication pattern of each awardee and thereby allow conclusions on changes during the career of the Wittgenstein awardee, i.e. whether the Wittgenstein awardee published in more or new disciplines than before the award. In order to relate these changes to the Wittgenstein award, the disciplinary distribution before the award was compared to the funding period. In a second analysis the disciplinary distribution of the funding period was compared to the period after the Wittgenstein award.

\section{Case studies, interviews and validation workshop}

Key informant interviews were held with representatives from the FWF, the Federal Ministry of Science, Research and Economy (BMWFW) and the START Jury. In total, eight representatives have participated in interviews and group discussions between April and June 2015.

Eight case studies covering eight START projects were realised. The selected cases represented a variety of START projects with a view to disciplines, period of 
funding and their institutional setting. For the purpose of the case studies, the following group of people was interviewed over the telephone: eight START grantees; six members of five research organisations hosting seven of the eight investigated START projects; nine START project group members, covering six investigated START projects. The interviews were conducted between May and July 2015.

Interviews with Wittgenstein awardees: Between June and July 2015 seven Wittgenstein Award winners were interviewed on the telephone or face to face. The selection of the interview partners was based on the following criteria: discipline, gender and time the award has been won.

The validation workshop was held on September $24^{\text {th }} 2015$. Participants from the FWF, the ministries, from universities as well as START and Wittgenstein awardees participated. 


\section{Evaluation of the START Programme}

The START Programme was created in 1996 together with the former Ministry of Research, Transport and Art (BMWVK). Until 2009, the Austrian Science Fund (FWF) administered the programme on behalf of the ministry; since 2010, the programme is part of the aoutnomous funding portfolio of the FWF. The START Programme provides a research grant of up to 1.2 million Euros for a time up to six years for individual researchers. This grant can be spent freely on research personnel or infrastructure. With this grant, "researchers should be given the long-term and extensive financial security to plan their research and to build up or consolidate their own research groups thereby qualifying themselves for senior research positions (especially as university professors within Austria or abroad)."4

Between 1996 and 2014, a total of 114 START grantees were funded, each year between six and eight, exceptionally nine projects. A mid-term review is carried out after three years of funding. Since 1996 and until 2015, around 132.6 million Euros were allocated to the START Programme5. The START Programme targets outstanding young researchers of any discipline and nationality. Recently, the applicant to the START Programme must have completed his/her PhD for at least two years but not longer than eight years, have to prove an exceptional international track record and research independence and must be willing to conduct the START project in an Austrian research institution.

The proposals of the applicants are assessed by an international jury. Between 2002 and 2014 , the average success rate of the application was $13 \%$.

As a result of an evaluation conducted in 2006 and the introduction of the ERC Grants on the European level in 2007, the application modalities have changed since 2006. The three most important changes were:

- the possibility to regularly fund the awardees' own position ('Selbstantragsstellerlnnen'),

- the introduction of a "hearing" in the selection process,

4 FWF homepage; https://www.fwf.ac.at/en/research-funding/fwf-programmes/Startprogramme; visited on 29/07/2015.

5 Due to premature terminations of START projects (e.g. due to an appointment to a foreign research institution or other reasons), the disbursed sum is lower. 
- the shift from an age limit for application (35 years before 2006) to a range of years after the $\mathrm{PhD}$ award (2 to 10 years after PhD graduation in 2006, with a gradual decrease to 2 to 8 years after PhD graduation since 2014),

- the obligation to apply for an ERC grant in parallel.

Since the introduction of the ERC Starting grant, the START applicants have been obliged to apply for an ERC grant in parallel. In case of a successful application of both the START and the ERC grant, the research is funded by the ERC grant. In order to compensate the double application, the ERC/START grantee receives a supplementary funding from the FWF, amounting to approximately one annual research year (max. 200,000 Euros). Furthermore the grantee is allowed to keep the title "STARTgrantee".

After having existed for almost 20 years, the appropriateness of the design with regards to today's need and the impacts that the programme has produced in this time span, is to be assessed. This is the objective of the following analysis. It is divided into three main parts:

In chapter 3.1 the role and position of the START Programme within the overall FWF programme portfolio is investigated. This chapter looks in particular at the objectives of the programme and the role it plays within the Austrian research funding landscape. Furthermore, the interaction between the START Programme and its European homologue, the ERC Starting grant is analysed.

Chapter 3.2 is an analysis of the programme management during the application stage and the programme's implementation and includes an assessment of the selection process.

Chapter 3.3 is an analysis of the achievements of the START Programme regarding scientific performance, career development and institutional integration of the START grantees, as well as the effects on the START project group members.

\subsection{Internal Positioning of the START Programme in the FWF Funding Portfolio}

This chapter analyses the objectives of the START Programme, their relevance towards today's needs in the Austrian research system and the appropriateness of the overall programme design. A further aspect which has been investigated is how well the START Programme fits into the funding portfolio of the FWF and the Austrian research funding system in general. A specific focus is put on the analysis of the ERC Starting Grant in comparison to the START Programme. 


\subsubsection{Programme Design}

\subsubsection{The Objectives of the START Programme}

The description of the START Programme, as formulated by the FWF6, shows four main underlying objectives:

- Promoting the scientific performance of the grantees: Young and promising researchers should be given the possibility to excel in their research discipline through long term funding.

- Gaining experience in managing research groups: Young researchers should get the possibility to gain experience in the organisation and management of research groups over a time period of six years.

- Promoting career development of young researchers: this objective has been introduced with the contract amendment of 2006 and allows the START grantees to finance his/her salary out of the START funding. ${ }^{7}$

- Promoting the understanding and acceptance of research by society: due to its orientation towards individual researchers and a particular research project, the START Programme offers a possibility to make research tangible for a broader public and explain the necessity for its funding by public authorities.

In the following, the objectives of the START Programme are discussed in more detail, taking into account the view of the different stakeholders with regard to the aims and objectives that are linked to the programme.

\section{Promoting the scientific performance of the START grantees}

The amount and long term character of the funding as well as the high level of freedom and flexibility in research constitute the basis for promoting scientific performance in basic research and blue sky research. As one jury member pointed out: "Young people can take a deep breath and start something which is not in the pipeline of their previous work. It is so important to have time to make something originally." The flexibility and freedom within the programme for the researchers enables them to follow unexpected paths and unconventional methodological approaches.

6 https://www.fwf.ac.at/fileadmin/files/Dokumente/Antragstellung/Start-Programm/y_programaims.pdf (visited 29/07/2015)

7 Before 2006, the START grantee had to prove a working contract for the time of the START project. While there have been cases of START awardees that financed their salary from the START funding, this was only possible on specific request. 
For the surveyed START grantees the 'freedom to concentrate on research over a longer period' was one of the main motives to apply for the START Programme (see figure below). For $71 \%$ this was a very important motive, for $21 \%$ this was still an important motive for application. Also the aspect 'opportunities for unconventional research' was highlighted by $53 \%$ as a very important reason for application.

Figure 1: $\quad$ Motives for a START application: aspects related to the research group (START grantees)

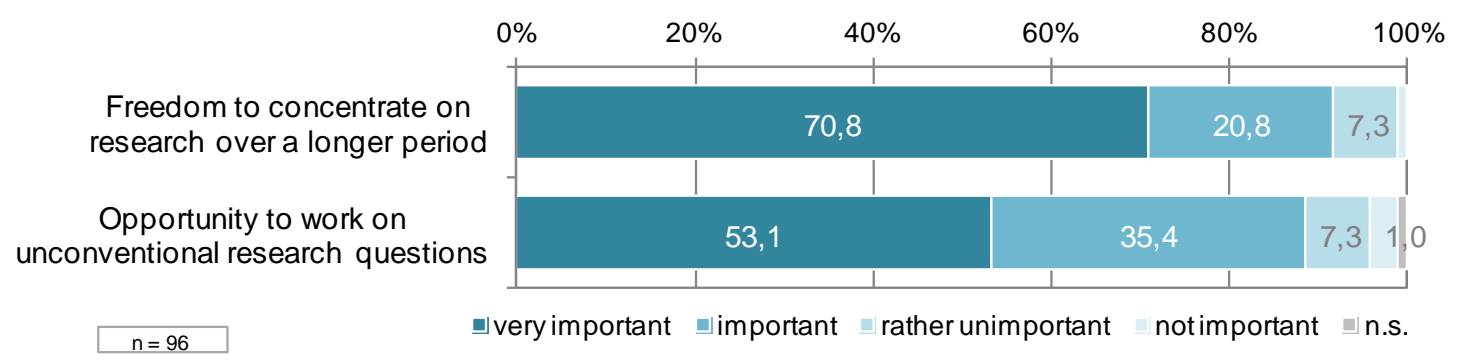

Question asked: "How important were the following motives for your START Programme application?"

The results are confirmed by the case studies. The amount and the long-running nature of the funding in combination with a high level of freedom in research were mentioned as a strength of the START Programme by the START grantees. This enables the researchers to go more in-depth and to push their research in unknown directions. As described by a START grantee: "Hier kann man Visionen entwickeln und muss nicht stückeln".

\section{Gaining experience in managing research groups}

The possibility to 'building up an own research group' seems to be one of the main motives for an application to the START Programme. 95\% of the survey respondents state that this was a very important or important motive. The high expectations towards this aspect can be explained by the fact that START officially gives the grantees the role of a group leader and thereby the responsibility to manage researchers; a task they often had performed already before, but without official recognition. In the words of the grantee, this reads as follows: "Dadurch konnte ich zeigen, was ich allein kann." "Ich bin für meine Doktoranden selbst verantwortlich, sonst steht immer der Chef drauf." Building up a research group promotes the independence of the project leader, which must be seen as a prerequisite to advance their careers and to qualify for permanent positions in academia. Especially in the humanities the possibilities to lead a group are rare.

However, gaining experience in the underlying competences related to training for such group leader positions is not a primary motivation for applying to the START Pro- 
gramme. Not even half of the respondents indicate that "gain experience in management \& HR management" was an important reason for their application.

Figure 2: $\quad$ Motives for a START application: aspects related to research management (START grantees)

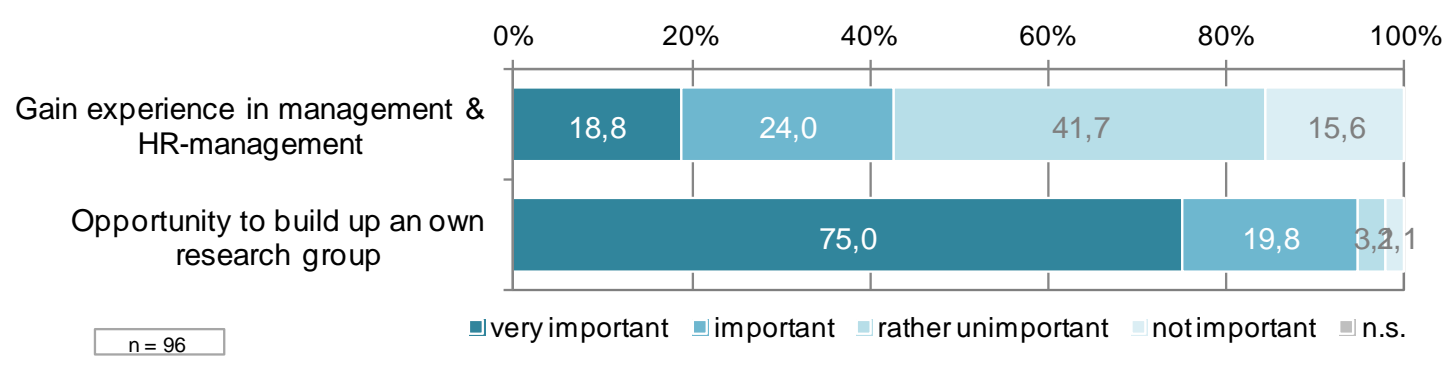

Question asked: "How important were the following motives for your START Programme application?"

\section{Promoting career development of young researchers}

The START Programme is seen by the START grantee as a good stepping stone to a research career. For $67 \%$ of the respondents the aspect 'improvement of own career prospect' was a very important motive for applying to the START Programme. Survey respondents were more hesitant when it came to the formulation of expectations related to the longer term outcomes of the programme: for $47 \%$ the aspect 'obtain a permanent position in academia' was a strong motive for application.

Figure 3: $\quad$ Motives for a START application: aspects related to career development (START grantees)

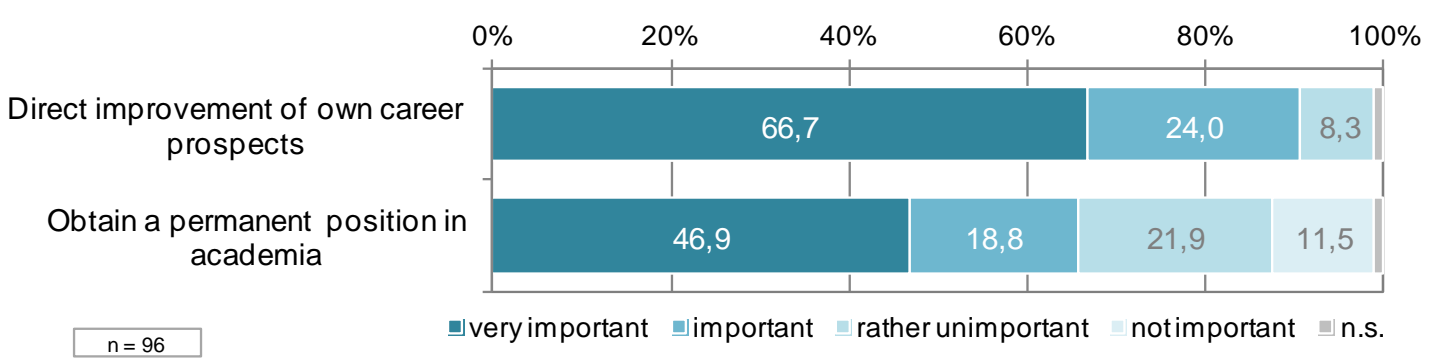

Question asked: "How important were the following motives for your START Programme application?"

Researchers from the control and comparison groups the START Programme definitely see it as an instrument that helps to consolidate a research career. Almost $80 \%$ of the respondents of the control and comparison groups agree with the statement that the 
START Programme is a suitable instrument to help junior researchers to obtain a permanent position in the Austrian research system.

Figure 4: $\quad$ START as an instrument for promoting career development (control and comparison group)

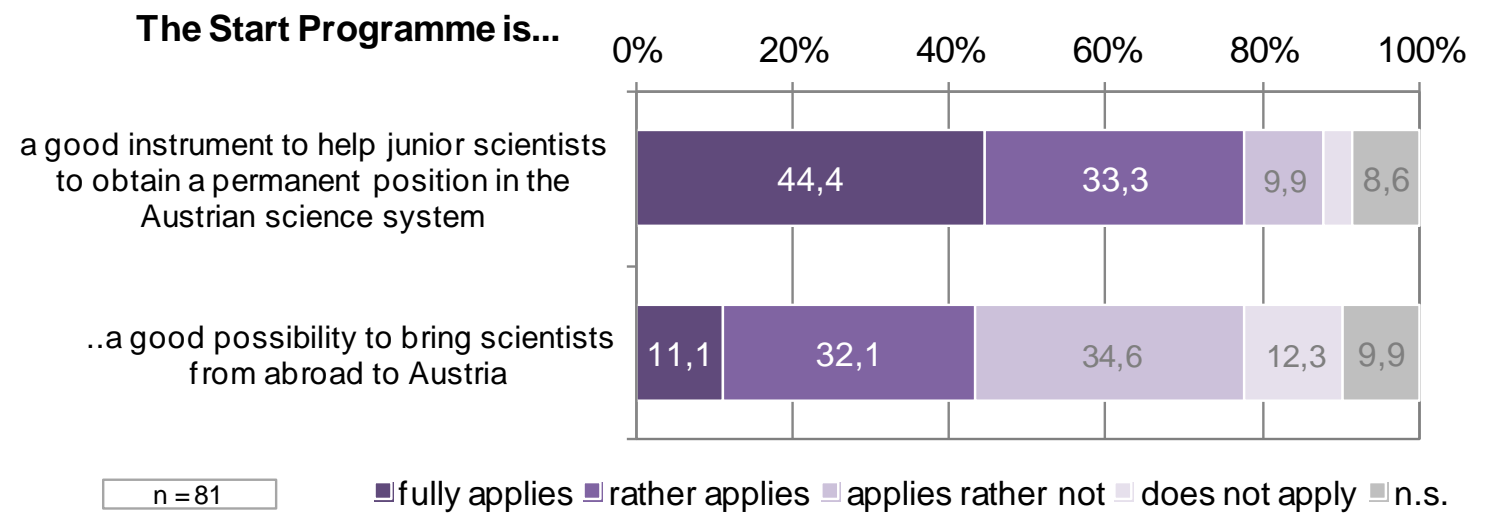

The interviewed staff of the FWF is convinced that the programme represents a career boost ("massives Karrieresprungbrett", "ein Beschleuniger") as it is highly competitive and proves the excellence of the grantees and enhances their visibility among the research community. Also the jury emphasises the importance of the programme for the researcher's career. In the view of the institutional stakeholders, the programme includes also an incoming element. With the amendment of 2006 ("Selbstantragstellerlnnen") the programme can contribute to motivating top researchers to come or return to Austria and settle in an Austrian research institution. From the perspective of nonfunded researchers, the START Programme is, however, not seen as a primary instrument to attract foreign researchers (see graphic above).

\section{Promoting the understanding and acceptance of research by society}

Each year, the names of the START grantees are made public and the START Programme is a topic in Austrian newspapers and other mass media. In the opinion of the surveyed groups, the START Programme strengthens the visibility of the funded researchers as well as the Austrian basic research ("START führt zu medialer Aufmerksamkeit, man ist nicht so leicht zu ignorieren."). Furthermore, $64 \%$ of the START grantees indicate disseminating their research results to a non-scientific public, through publications and contributions in mass media, as described more in detail in Figure 20 in chapter 3.3.3. 
Figure 5: $\quad$ Visibility of the START Programme

The START prize strengthens...

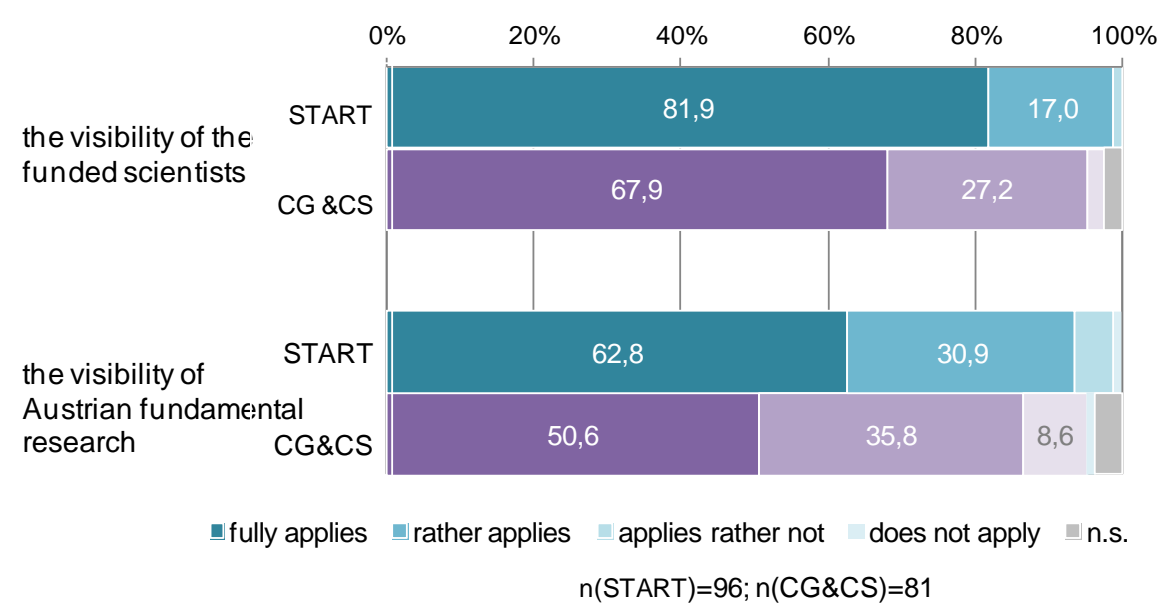

\section{Suggestion for an impact diagram of the START Programme}

Based on the programme objectives and the subjective perceptions of the stakeholders, the study team drafted the following diagram which summarises the (assumed) effects of the START Programme. It combines the different objectives that are associated or perceived with the START Programme with the inputs that are currently provided with the aim of tracing possible pathways of effects. In this sense, one may speak of a "reconstructed" impact pathway of the programme in its present form. 
Figure 6: $\quad$ Impact diagram of the START Programme

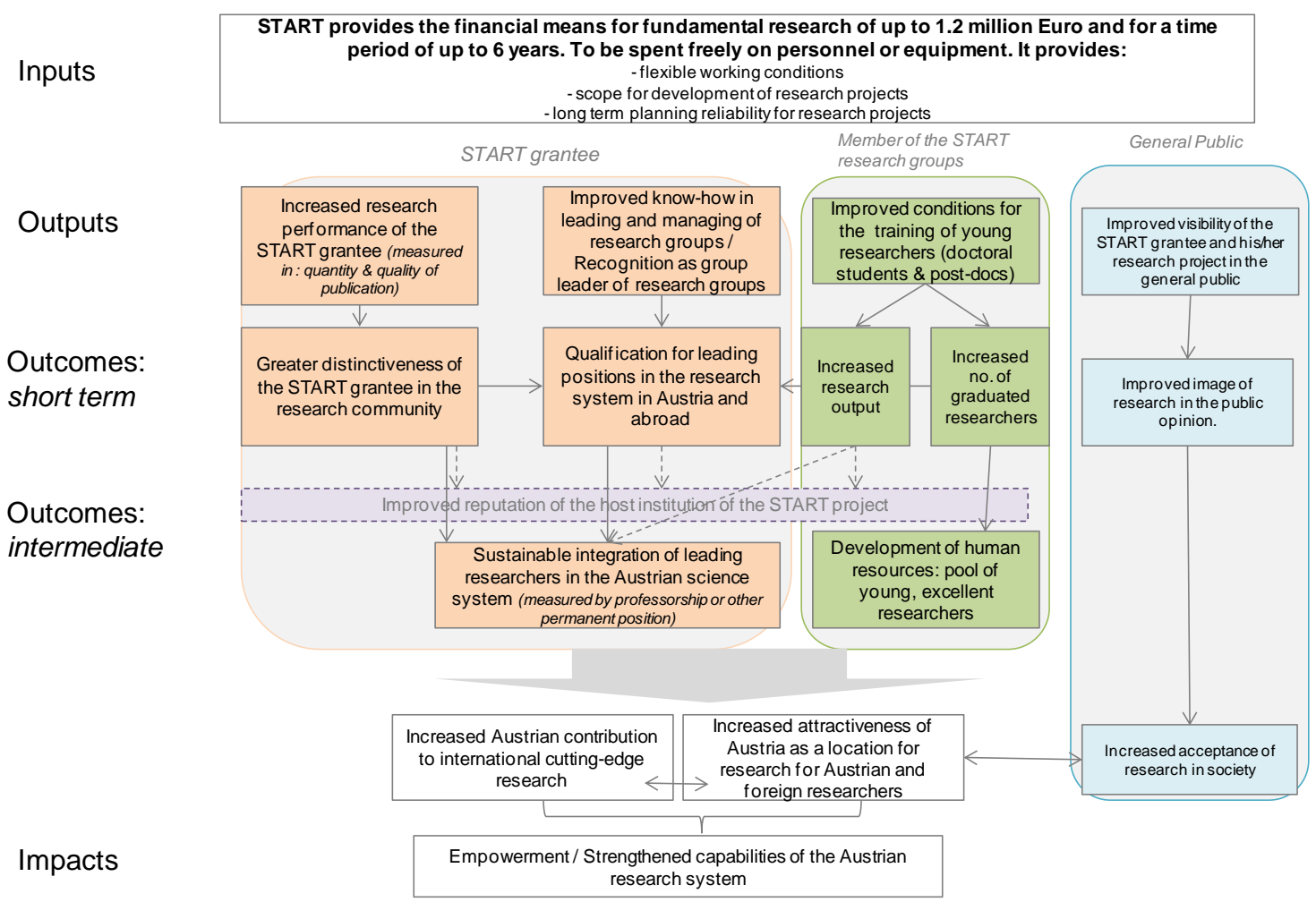

It must be noted that such a linear diagram cannot reflect the complex reality of the interaction and interconnectivity of the different effects and stakeholder accurately. The arrows are thus an attempt to reflect the directions of effects and interaction.

Three groups of stakeholders can be distinguished. Different effects are expected on each group.

The primary and direct target group of the START Programme are the START grantees themselves. They are also the group on which the strongest effects are expected. START grantees are expected to increase their scientific performance and in parallel to qualify for leading positions in the (Austrian) research system.

The second group, which is targeted by the START Programme, are the members of the START project groups. These young researchers profit from the guidance of toplevel researchers. In the long run, they are expected to perform internationally recognised top level research themselves and widen the human resource pool of the research system in Austria.

The third group targeted by the START Programme is the wider public in Austria. By providing funding to individual researchers the possibility arises to communicate and 
explain research to a wider public and thereby increase acceptance for research in general and the necessity for its public funding.

In a longer time perspective, the START Programme is expected to contribute to strengthening the Austrian research system, which is recognised as a performing and attractive system by researchers and research stakeholders in and outside Austria.

Whether and to which degrees these expected results of the START Programme have been achieved, will be discussed in chapter 3.3.

\subsubsection{The START Programme within the FWF Portfolio \& the Austrian Funding Environment}

The START Programme targets researchers at a late stage of their post-doc phase, at the edge of professional establishment into academia. Consequently it is seen as the "top" career development instrument.

From the analysis of the FWF portfolio and from survey and case study responses, it appears that the START Programme is unique in Austria, as it is the only funding possibility for post-doc researchers which is open to any discipline and provide a critical mass of resources for a long period of time. Although this phase is decisive for the sustainable establishment in the research system, there are hardly any alternatives, with the exception of programmes addressing women such as the Elise Richter programme, and the WWTF "Vienna Research Groups for Young Investigators" which focuses, however, on selected disciplines.

The survey of the START grantees emphasises that the funding opportunities for the early post-doc phase are perceived as rather better than the respective opportunities at the later post-doc phase, i.e. from four years after the $\mathrm{PhD}$ graduation (see graphic below). With regard to the FWF portfolio, more than $50 \%$ of control group respondents also see funding gaps in the post-doc period. 
Figure 7: $\quad$ Assessment of appropriateness of funding opportunities during the post-doc period (START grantees)

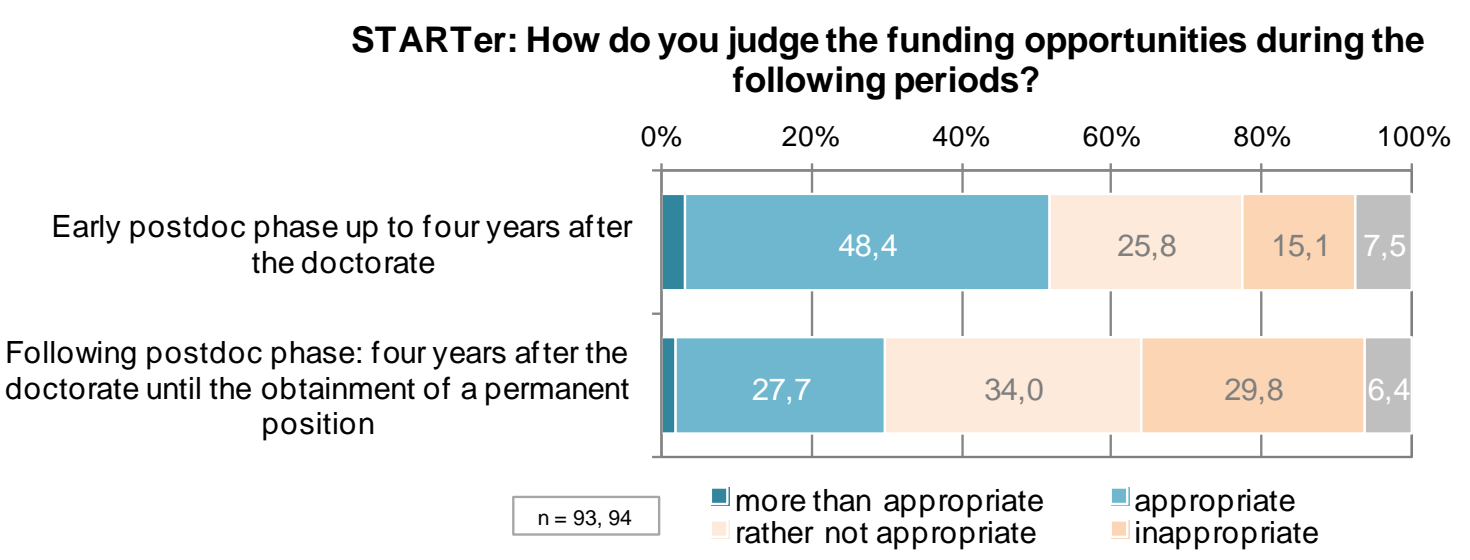

Question asked: "How do you judge the funding opportunities during the following periods?"

As funding possibilities in the early post-doc phase are seen as rather appropriate by the researchers, none of the START grantees mentioned in the interview the need for a "pre-START Programme". However, such a pre-START Programme is discussed by the stakeholders ("Dieses Pre-START geistert schon ein bisschen herum"). The discussion first appeared with the implementation of the ERC (see below) and the question on how to react to it. At the time, it was discussed whether START should be changed into preparatory programme for the ERC. The arguments for a pre-START Programme put forward by universities are the following: a pre-START Programme would be better distinguished from the ERC grant and this would sharpen the actual profile of the START Programme; it would furthermore tackle the funding gap for postdoc researchers ("Wir haben budgetäre Schwierigkeiten bei post-docs. "). Especially in the humanities and the social sciences such a pre-START Programme is seen as attractive. In those disciplines the research independence is reached rather late and work in research groups seems to be unusual. It must be stressed that none of the interviewees, except one representative of a university, suggested ending START in favour of a kind of Pre-START. Instead a model with two steps ("Ein Zwei-Stufen-Modell wäre eine sehr gute Sache") has been suggested, e.g. taking a similar design to the current Hertha Firnberg / Elise Richter programme. Admittedly, such a model requires an increase of funding which seems not realisable taking into account the current budget situation.

The survey respondents are familiar with the Austrian funding system, as the responses show. The surveyed researchers apply or have applied for a large variety of projects and funding. All three surveyed groups (START grantees, the comparison group (CG) and the candidate to the START Programme (CS)) are relying on similar 
funding in the post-doc phase, namely stand-alone project grants from the FWF, the Erwin Schrödinger Fellowship and other funding, most of them being international or regional grants. A particular pattern can be shown for the $C G$ which relies to a high extent on funding from the Austrian Research Promotion Agency (FFG). The grants from OeNB are also more often used by CG and CS than by the START grantees.

\subsubsection{ERC \& START}

The ERC grant was introduced in 2007 and shows very similar features to the START Programme, concerning its objectives, the target group and the provided financial means. 8 As START was a very successful and well-established programme, it was never an option to abolish the programme in 2007. Instead, the requirement for a double application (with the same research project) has been adopted, putting forward the argument of the similarity of the programme requirements, the limited funding possibilities for post-doc researchers, and the low success rate of both programmes. 9

In the case that a START grantee is granted also an ERC, he/she has to give back the START funding. 10 As START is funded for six years and the ERC Starting Grant only for five years, the FWF funds the costs for the $6^{\text {th }}$ year to compensate for the drawbacks the grantee has from a double application. Furthermore, the researchers continue to carry the title "START grantee". Within the FWF, this requirement is not indisputable.

\section{Appropriateness and timeliness of the obligation for a double application}

The introduction of the ERC grants has generated a discussion on the legitimacy of the START Programme in Austria.

The double application is seen as a pragmatic way to save money, in the case another funding opportunity for the same project arises and the free funds can be used for new fundings. ("Pragmatisch war das natürlich richtig."; "Ich verstehe die Logik des FWF dahinter.") Moreover, it raised the Austrian application rate to the ERC and meanwhile

8 A detailed comparison of the START Programme and ERC can be found in the Annex.

9 The average success rate (2002-2014) for the START Programme is of $13 \%$; the success rate of the ERC Starting Grant is of 10\%. (average of 2007-2014)

10 Prohibition of double funding for the same project by national and EU funding at the same time. 
the ERC is well known and used in the Austrian research community ("Der ERC ist angekommen.").

However, the requirement for a double application is also seen as problematic by institutional stakeholders ("Das Doppelantragsgebot ist unschön."). Several arguments are put forward: Firstly, the young researchers should be able to choose themselves to which programme they apply ("Nicht gut, jemanden zu etwas zu verpflichten."). Secondly, due to the blocking periods within ERC, some researchers cannot apply for an ERC Grant a second time in case of failure ("Zeitfenster werden sehr eng"). In former time, divergent application modalities forced some START applicants to apply for the next higher grant, the ERC Consolidator Grant. This produces hardship cases. Moreover, candidates who would have the potential to conduct two research projects of the type START/ERC are not allowed to hand in different project proposals. ("Es gibt durchaus Leute, die zwei solche großen Projekte auf die Beine stellen können.").

Thirdly, ERC is seen as even more competitive as START. As discussed above, START could then be a preparation for applying to an even more competitive ERC at a later career stage. Also some interviewed START grantees argue against the double application and highlight especially the potential that the START Programme has for preparing an ERC grant. One interviewee reports that after refusal of her first application (to ERC) she applied successfully a second time for an ERC on the basis of preliminary results of the START project ("Das war optimal, dann war ich super vorbereitet auf ERC."), another received an ERC Consolidator Grant for ideas grounded on the successful START project. Also the control and comparison groups see the START Programme as a good instrument to prepare for an application for an ERC grant.

Figure 8: $\quad$ The START Programme as an instrument for preparing for an ERCStarting grant application (Control and comparison group)

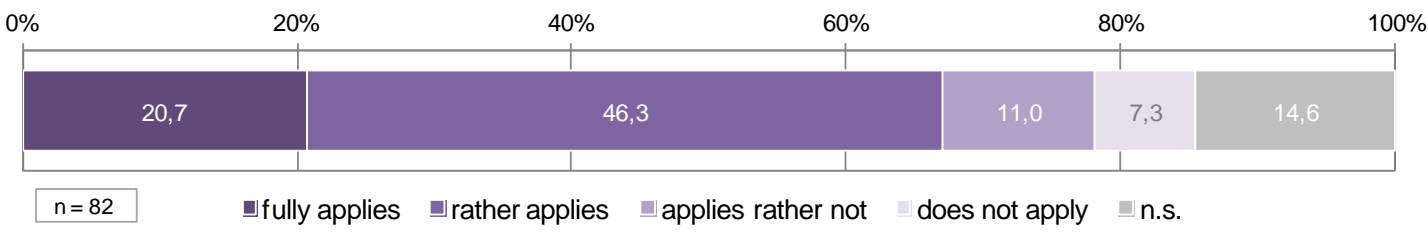

The research institutions are at strife, too. Whereas some appreciate the requirement for a double application ("kein schlechtes System") and the possibility to fund more START projects, others see in this obligation an additional burden for the researchers ("Das ist Schwachsinn, eine Bevormundung und eine Zusatzbelastung. ").

The START grantees are not as negative towards the obligation of a double application as the institutional stakeholders. Less than half of the respondents would like to see the 
obligation to apply for both grants abolished (see figure below). And almost $60 \%$ of the surveyed START grantees would have sent an application for both START and ERC even without the obligation.

Figure 9: $\quad$ Obligation to apply for START \& ERC in parallel

(START grantees after 2006)

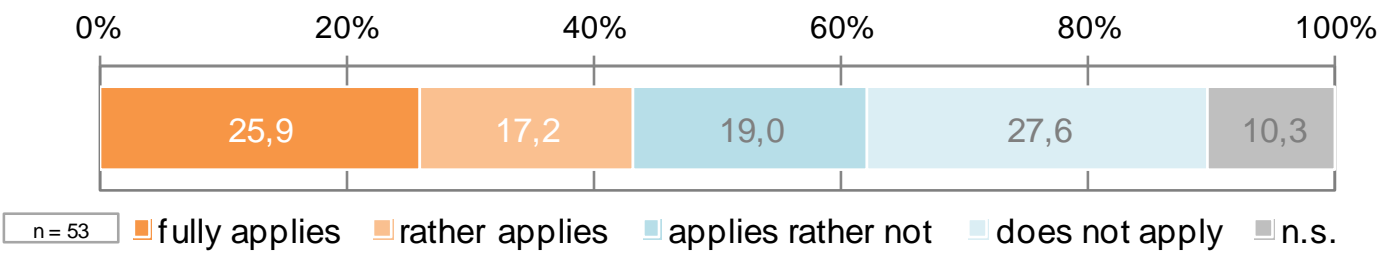

Question asked: "The obligation to apply for both grants should be abolished."

Also most of the interviewed START grantees found the double application a good idea ("Good, that you can apply with the same project.") with an added value, mainly for the humanities ("Das zwingt uns Geisteswissenschaftler auch in internationale Projekte." "Es hat mich viel Zeit gekostet, aber ich habe viel gelernt für zukünftige [EU-] Anträ$g e^{\prime \prime}$.

The survey results also support the opinion that the START Programme has its own legitimacy in the Austrian research funding portfolio, as it is highly valued by all three surveyed groups (see figures below). The main arguments for the coexistence of these two programmes are the exceptional resources both programmes provide to young researchers in a decisive career phase and the fact that both programmes distribute only few grants ("Das ist eh schon ein Würfelspiel, es ist sehr wichtig, eine Alternative zu haben.").

Additionally, the programme contributes strongly to the attractiveness of the research location Austria, as START is linked to an Austrian research institution. ("Ist ein starkes Argument für die Unis, damit sie Leute holen können. Ich hatte meine Stelle schon, aber es war ein wichtiges Argument hierher zu kommen, dass es sowas gibt." "Other countries have a national programme as well."). This holds especially true against the background of lacking alternatives for post-doc researchers ("START muss bleiben, solange Unis keine start-up packages haben."). The START Programme, even though internationally not as known as the ERC Starting grant, is seen as a valuable alternative to ERC. 
Figure 10: $\quad$ Comparing the START Programme to the ERC Starting grants

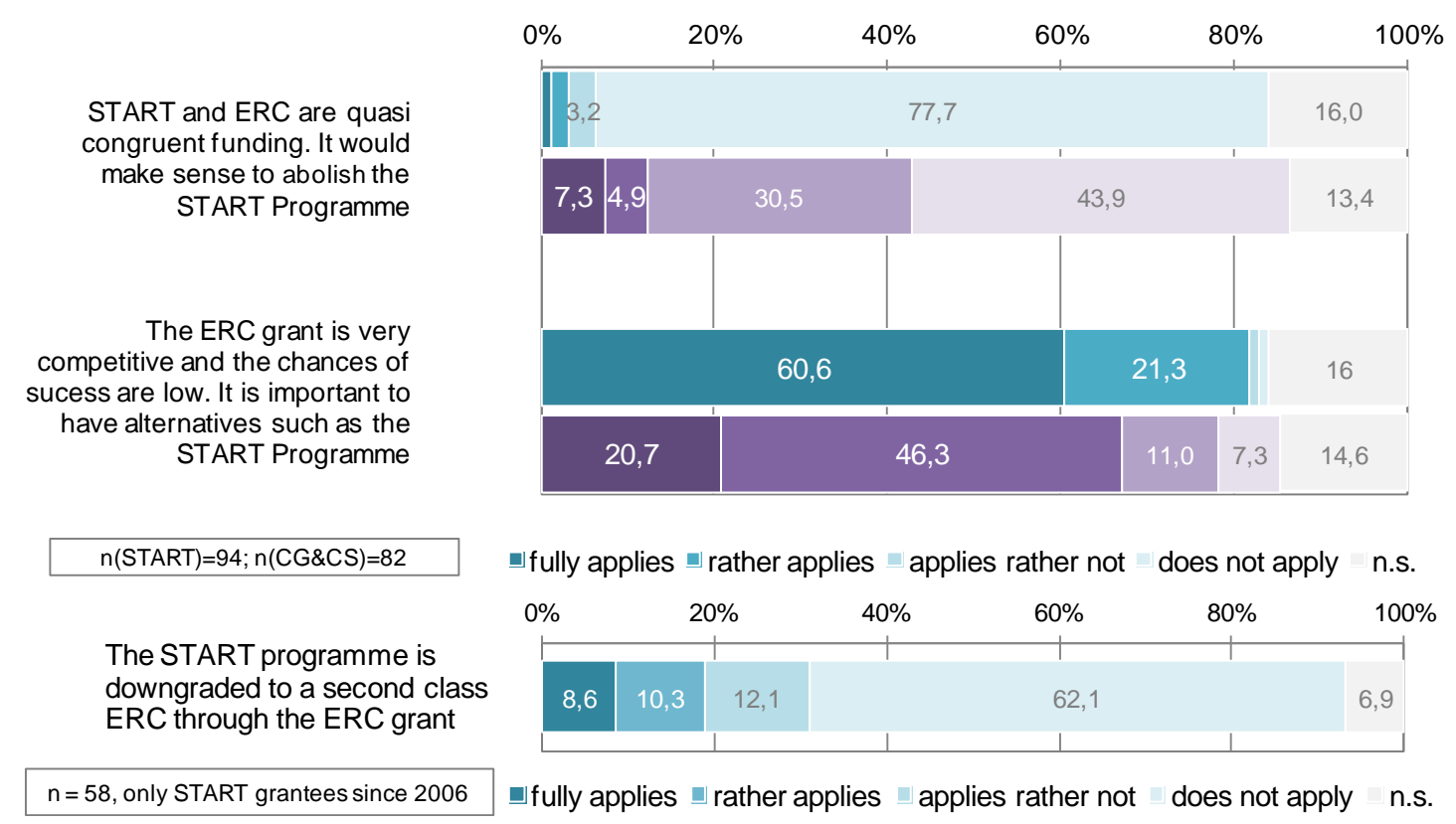

\section{Comparison of the administrative requirement in START and ERC}

While the research project with which the researchers apply for ERC is the same as for START, different administrative modalities, conditions and timeframes applies and add supplementary work for the applicants.

Against this background it is positive that around $50 \%$ of respondents acknowledge that the additional administrative burden arising from this requirement is still reasonable. This is also confirmed by the interviewed START grantees: "Der Aufwand ist nicht so groß, ein bis zwei Wochen Mehrarbeit."

Survey participants also recognise that the FWF reacts flexibly towards possible conflicting situations. For example, when the START applicants were not any longer eligible for an ERC Starting Grant and too "inexperienced" for an ERC Consolidator grant, the obligation for a double application was dropped. Only $43 \%$ of survey participants would prefer not being forced to submit an ERC proposal when applying for START. 
Figure 11: $\quad$ Administrative burden related to a double application START/ERC (START grantees after 2006)

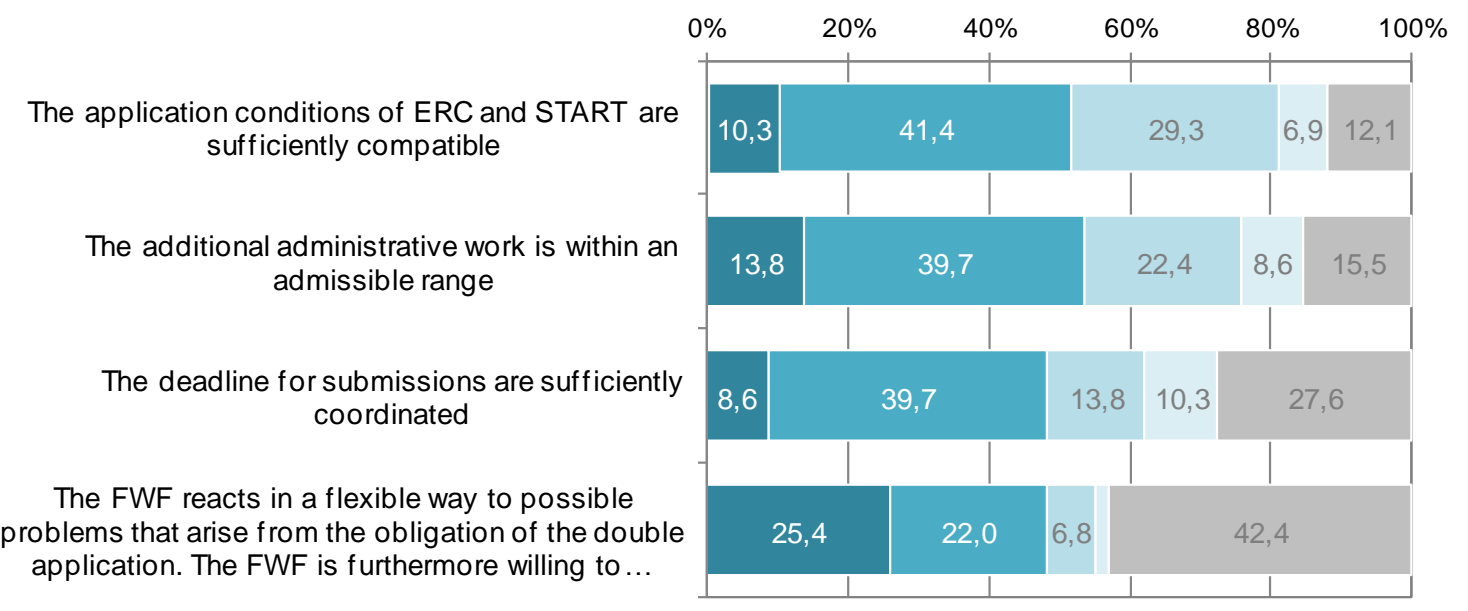

$\mathrm{n}=58 \square$ fully applies $\square$ rather applies $\square$ applies rather not $₫$ does not apply $\square$ n.s.

Large credit is notably given to the flexibility the START Programme allows and its low administrative burden, especially compared to the ERC procedures. This has also been confirmed in the framework of the case studies. ("Muss dem FWF ein Loblied singen, auch im Vergleich zu Brüssel."). All ERC-START grantees responding to the survey highlight the smooth and unbureaucratic management of the START Programme (e.g. flexible shift of funds, global budget) and value the personal and direct interaction with the FWF (e.g. individual reaction and solution orientation in the case of problems), as can be read in the next box

Box 1:

The management of the START Programme seen by ERC grantees

\section{Views from the survey and the case studies}

- „START: wunderbar unkompliziert und einfach, gute administrative Betreuung durch FWF Beide vergleichsweise unkompliziert, wobei START noch klar besser in dieser Beziehung ist."

- „Administrative Abwicklung von START ist viel flexibler und persönlicher.“

- „Der administrative Aufwand ist aufgrund des Globalbudgets im START-Projekt deutlich geringer und forscherfreundlicher."

\subsection{Programmme Management}

The following chapter investigates the programme management of the START Programme. It includes an appraisal of the selection process and shows how the administrative requirements in the application phase and during the START project implementation are perceived by the applicants and START grantees. 


\subsubsection{Target Group and Selection Process}

\section{Target group \& selection process}

The target group of the START Programme are outstanding young researchers of any discipline and nationality. Accordantly, the sole selection criterion is research excellence of the researcher and his/her research project. In the following, the selection process is described and the views on the process as perceived by the different stakeholders involved are discussed.

\section{The selection process}

Today's selection process consists of a two-step approach, as depicted in the graph below. It should be noted that the step 2 "hearing" was introduced in 2006.

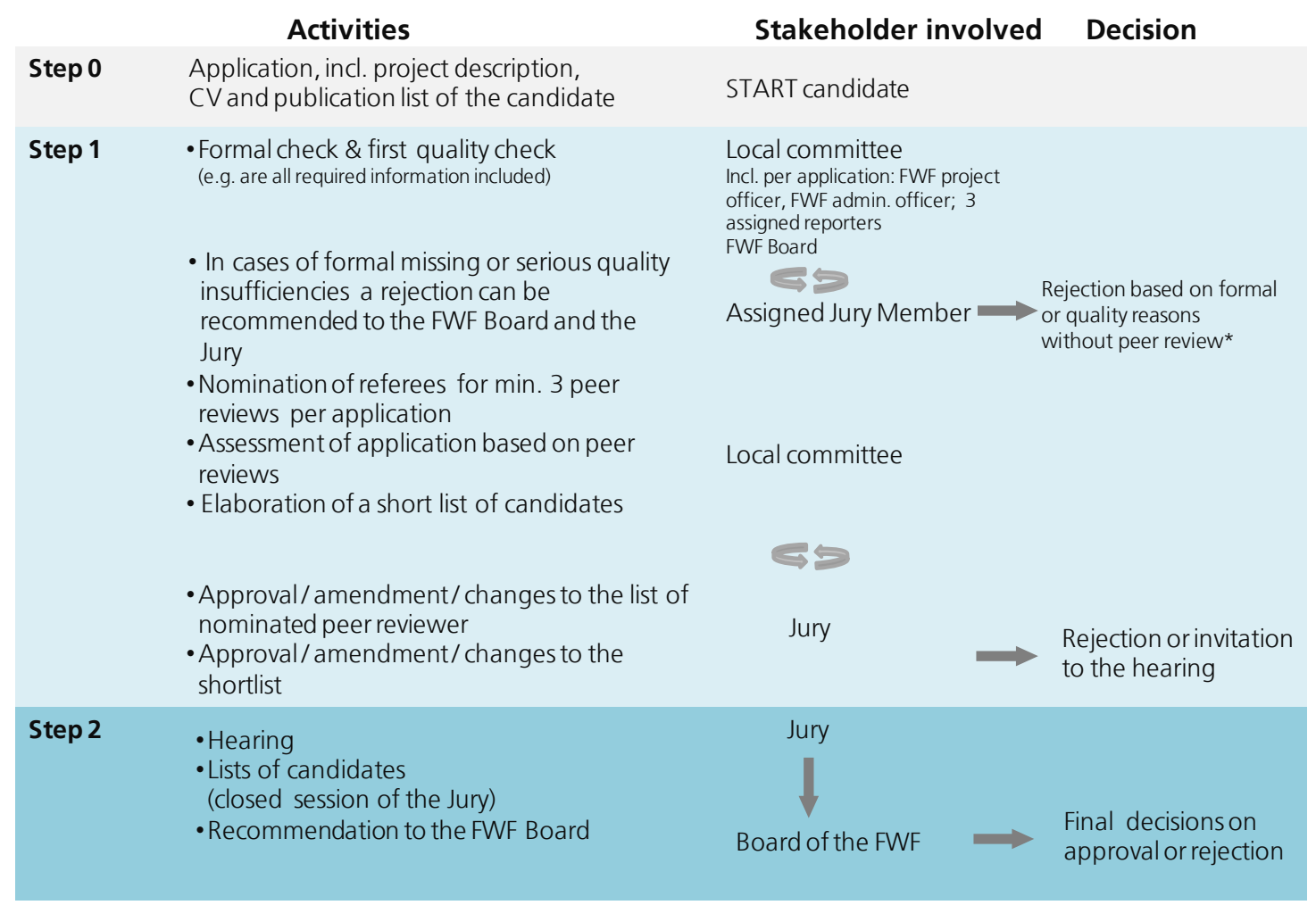

* In order to guarantee an unbiased selection process, the FWF requires that all applications are externally peer reviewed. However, a rejection of the application without peer review on the basis of formal or quality issues is possible, but has hardly been used in the last few years, as the applications are of good formal quality. 


\section{The international jury}

Its international jury is the only decision taking committee of the START Programme. All decisions have to be pronounced by this jury. It is composed of 14 international members of different disciplines. All jury members are renowned and established researchers in their respective fields. There are no official quotas for the disciplinary distribution of the jury. However, the jury should to a certain extent reflect the disciplinary distribution of past applications. The appointment of new jury members is thus made with regard to this aspect. Jury members are appointed for a duration of five years with the option for an extension of up to ten years. While this timeframe is seen as generally appropriate, the next year (2016) will bring a high turnover in jury members, as some of them will come to the end of their term at the same time. Concerns in the jury have been raised that a high turnover every ten years could be disadvantageous to the quality of decisions. Therefore, the jury suggests appointing jury members on a more continuous basis. ("If I had known about the ten year limit, I would have resigned one year before." "Give one special exceptional year to three people on the committee (...), so that it would not be such a big change every ten years."). A continuous rotation would also guarantee a more heterogeneous constitution of the jury in terms of age ("It is good that we now have a big turnover, thus, the jury will become 'younger'".).

As mentioned in the graph, each application is assigned to one "[a]ssigned Jury Member". In case of interdisciplinary proposals two members are assigned. The member in charge is usually a person with a similar disciplinary background. Approximately half of the jury members have three or four applicants for which they are responsible, the other half is in charge of one or two applications. Although there is one "assigned" member, the jury discusses each application together. In this process the jury highlights that they take care that no jury member pushes his/her applications based on purely disciplinary preferences. The final decision is taken by the entire jury in a closed session based on the information of the peer reviews and the hearing.

The jury is strongly supported in the selection process by a so-called "local committee". This committee includes members of the 'Kuratorium', the FWF decision board. Each application is followed by three assigned FWF board members, called "reporters". These board members are appointed by the FWF for a period of three years and are researchers in an Austrian research institution and from a discipline similar to the one of the candidate. The local committee has the task to review the application, nominate external peer reviewers and establish a shortlist of preselected candidates for the hearing. The local committee thus plays an important role in preparing and structuring the jury's decision making process. This is confirmed by the jury, which indicates that this 
pre-selection work is an important step in the process, as for time reasons it would not be possible for the jury members to look at all applications.

All in all, the jury members are highly satisfied with the application and the selection process and state to be very proud of being part of the process ("We were happy in the beginning, we are leaving happy.").

\section{Excellence as sole criterion for selection}

The jury members do not favour quotas, neither with a view to disciplines nor to gender. For them, the main selection criteria are a very strong orientation towards basic research ("I am fighting for basic research.", "It is very important to have strong basic research.") and the applicant's research excellence. The relevant question in this context is whether new fields are explored ("Does he open new fields?"). The desired impact is first of all an increase in knowledge.

The hearing has the aim to complement the evaluation of the written application with a personal meeting, thus providing the jury with supplementary information reinforcing or revising the first decision. The START applicant is given 10 minutes to present herself/himself, his/her "vision" of the START project and the research environment in which he/she will operate the research. The presentation is followed by a round of questions \& answers for another 10 to 15 minutes. In the hearing the jury looks at the precision in presenting the data and the "logic flow of things" as well as the discussion. Here it is important how the applicants react to (unexpected) questions.

With regard to presentations and the eloquence in the discussion, the jury reports that the performance of the applicants becomes stronger every year ("they become better and better", "the quality is enhancing") and can be related to the good preparation and the coaching of the applicants by the FWF ("He [the programme manager] spends a lot of time with applicants and is a kind of mentor for them." "He forwards our remarks and comments and is an extremely important link between us and the young ones. "). The jury members stress how hard it is to select the best ones from these high-level candidates. It is comforting to know that within the START Programme good and promising individuals could apply again the following year, whereas this does not hold for the ERC Starting grant.

Bias of the selection process regarding disciplines, gender and region

Another possibility of looking at the selection process is the quantitative analysis of number and nature of applications. The following analysis has compared all Austrian researchers to the candidates and to the successful START grantees with regards to 
three features: gender, region, discipline. The analysis is performed on all candidates to the START Programme since 1996 - including the START grantees, candidates to the hearing and non-successful candidates - based on data provided by the FWF. The data of the Austrian researchers stems from the Scopus database.11

The analysis has been divided into two parts:

- A first analysis has been performed comparing all Austrian researchers to the candidates;

- In a second analysis the candidates have been compared to the START grantees. 12

\section{Gender distribution:}

The proportion of women applying for the START Programme is equivalent to the proportion of women in the Austrian researcher community. The proportion of female START grantees is slightly lower than in the group of all Austrian researchers. Statistically, however, gender is not a significant predictor for the receipt of a START grant. Therefore, it is not possible to speak of a gender bias.

Table 2: $\quad$ Gender distribution of START candidates and grantees

\begin{tabular}{|l|c|c|c|}
\hline & Total no. & Men \% & Women\% \\
\hline All Austrian researchers & 15.473 & $80.93 \%$ & $19.07 \%$ \\
\hline Candidates to the START Programme since 1996 & 788 & $80.20 \%$ & $19.80 \%$ \\
\hline START grantees since 1996 & 114 & $84.21 \%$ & $15.79 \%$ \\
\hline
\end{tabular}

It should be noted that the figures above show an average of the 20 years of existence of the START programme. While in the first 10 years of the programme the female candidates made up approximately $10 \%-15 \%$ of all candidates, this changed in the last eight years, with a female participation rate of around $25 \%$. However, the proportion of women graduating with a doctoral degree or working as researcher at university in a

11 i.e. a researcher who has at least one publication for which the affiliation is an Austrian research institution.

12 An overview of the distribution of START grantees and candidates with regards to gender, distribution of regions and disciplines can be found in the annex "overview on the applicants to the START programme". 
non-permanent position ("Wissenschaftliches Personal") 13 was above $40 \%$ for both categories, in the last years. 14 The potential target group of the START programme therefore probably comprises more women than there are currently female applicants to the programme.

\section{Regional distribution:}

Three main regions have been chosen for analysis 15 :

- Region 1: Eastern Austria, including the Vienna region, Burgenland and Lower Austria,

- Region 2: Southern Austria, including Carinthia and Styria.

- Region 3: Western Austria, including Upper Austria, Salzburg, Tyrol and Vorarlberg.

With regard to the regional distribution there already appears to be an imbalance at the application stage: the proportion of START candidates from Eastern Austria (R1) is significantly higher than the proportion of publishing researchers in the region. In contrast, there are significantly fewer applicants to the START Programme coming from research institutions based in the two other Austrian regions, compared to the number of researchers based in these regions ( $R 2$ and $R 3$ ). ${ }^{16}$ The original imbalance in the group of candidates is, however, rebalanced to a certain extent in the START grantee group. While in the regions 1 and 3 the proportion of funded START grantees is now similar to the proportion of researchers based in these regions, researchers from region 2 are still significantly underrepresented. 17 The table below shows the distribution of researchers for each group and region.

13 Taking into account the Austrian academic system, it is assumed that most of the personnel in this category is a doctoral or post-doc researcher. Please note: Also the Universities of Applied Sciences are included in this category.

14 For detailed figures see Statistische Taschenbücher of the years 2008, 2010 and 2015. www.bmwfw.gv.at

15 The distribution is based on the NUT Nomenclature of Territorial Units for Statistics of the European Union. The NUT1-level has been chosen for analysis http://ec.europa.eu/euro stat/web/nuts/overview (last access 03/08/2015)

16 All three regions are significant at the level of $p<0.01$; Mann-Whitney-U Test.

17 Significant at the level of $p<0.01$; Mann-Whitney-U Test. 
Table 3: $\quad$ Regional distribution of START candidates and grantees

\begin{tabular}{|l|c|c|c|}
\hline & R1 & R2 & R3 \\
\hline All Austrian researchers & $54.46 \%$ & $19.55 \%$ & $25,99 \%$ \\
\hline Candidates to the START Programme since 1996 & $71.8 \%$ & $8.89 \%$ & $19.82 \%$ \\
\hline START grantees since 1996 & $64.91 \%$ & $9.65 \%$ & $25.44 \%$ \\
\hline
\end{tabular}

\section{Distribution of disciplines 18}

There is a certain imbalance in all disciplines during the application process, meaning that there are either more or fewer applicants than in the overall Austrian research population.

In particular, the share of applicants from the fields of mathematics, physics and social sciences and humanities (SSH) is significantly higher compared to the group of all Austrian researchers. In contrast, there are proportionally fewer applicants from the fields of biotechnology/medicine and natural sciences compared to the group of Austrian researchers.

The differences still persist once START grantees are selected and also the directions are further pronounced, i.e. more researchers from mathematics, physics are funded and fewer from biotechnology/medicine and natural sciences. Only in the social science and humanities the proportion of candidates and START grantees stays the same.

18 The present grouping of disciplines is based on journal publications. There are certainly candidates to the START Programme which are researching at the boarder of more than one of these five disciplines. As this holds, however, true for all three groups, the analysis can be seen as adequate. 
Table 4: $\quad$ Disciplinary distribution of START candidates and grantees

\begin{tabular}{|l|c|c|c|c|c|}
\hline & $\begin{array}{c}\text { Biotechnology } \\
\& \\
\text { Medicine }\end{array}$ & $\begin{array}{c}\text { Mathe- } \\
\text { matics }\end{array}$ & $\begin{array}{c}\text { Natural } \\
\text { Sciences }\end{array}$ & Physics & SSH \\
\hline \begin{tabular}{l|l|l|l|l|} 
All Austrian \\
researchers
\end{tabular} & $53.08 \%$ & $2.60 \%$ & $32.98 \%$ & $6.69 \%$ & $\sim 30 \%{ }^{19}$ \\
\hline Candidates & $31.73 \%$ & $8.38 \%$ & $25.25 \%$ & $21.45 \%$ & $13.07 \%$ \\
\hline START grantees & $22.81 \%$ & $15.79 \%$ & $20.18 \%$ & $27.19 \%$ & $14.04 \%$ \\
\hline
\end{tabular}

To sum up:

The analysis shows a different distribution in terms of region and discipline of applicants compared to all Austrian researchers already at the application stage. This means that researchers from particular regions or from particular disciplines (especially biotechnology \& medicine and natural sciences) do not apply or apply less frequently for START grants.

The analysis of the regional and disciplinary distribution of the START grantees compared to all Austrian researchers shows that there are certain areas (geographical and disciplinary) which receive an over proportional degree of funding. The concentration of START groups in a specific discipline and at a specific research institution, indicate the conclusion that there are today "hotspots of research excellence", which to a certain extent reproduce themselves with regard to receive START funding20. This is e.g. the case of the Physics department at the University of Innsbruck which since 1996 has hosted two START groups and one Wittgenstein awardee. The results thus confirm the well-known Matthew effect (success breeds success), but from a research-policy point

19 As Scopus represents the SSH disciplines only to a very limited extent (around $4 \%$ of all publication in the case of Austria), the She-figure report 2012 has been used. It provides data for 2009: according to this source around 30\% of Austrian researchers are in the field of SSH; around 17\% in Social Sciences and 14\% in Humanities (see pages 46 and 62). http://ec.europa.eu/research/science-society/document library/pdf 06/she-figures$\underline{2012 \text { en.pdf }}$

The distribution of START grantees is the following: 5.3\% from Social Sciences and almost 7.9\% from Humanities.

20 The argument of certain strong performing disciplines (esp. mathematics, physics and biology) is also supported in: Reckling, Falk et al. (2010). Factors Influencing Approval Probability in Austrian Science Fund (FWF) Decision-Making Procedures - FWF Stand-Alone Projects Programme, 1999 to 2008. Zenodo. 10.2139/ssrn.1725985 and in: Reckling, Falk. (2007). A contest between nations; or how far is Austrian research behind that of the world leaders? Zenodo. $10.5281 /$ zenodo. 16456 
of view it is often rather welcome that the national research systems dispose of such respective excellence centres. One should also note that application pattern within the above defined disciplinary groups already varies. This is for example the case in the SSH disciplines, where one finds proportionally often START grantees from the humanities (esp. history and archaeology), but to a lesser extent social scientists including economists.

\section{The view of the applicants on the hearing}

The application process was assessed by the interviewed START grantees as adequate ("state of art" and "painless"). The experience of the hearing, however, differed. Although all interviewees underlined the good atmosphere and organisation and emphasised that they had been well prepared by the FWF ("Besser, als was ich jemals davor und danach hatte"), some of them reported that it turned out to be a very difficult and stressful situation. Mainly the requirement to explain the project in 10 minutes and to discuss it with people who are non-experts in the respective field turned out to be a key challenge. In consequence several voices in the interviews but also in the survey suggested extending the time for the presentation to e.g. 15 minutes, as it is done in ERC hearings.

Another recurrent point mentioned in the interviews and in the survey is the composition of the jury. Here also the opinions differ on how the disciplinary heterogeneity of the jury influences the decisions.

Some START grantees recognise the performance of the jury and perceive the members as benevolent and well-prepared. ("It is a tour de force for them.", "Das Panel habe ich nicht beneidet - es waren sehr unterschiedliche Disziplinen."). However, especially the heterogeneity of the jury with regards to disciplines is seen as problematic, as a few voices from the survey show: "Nur wenige Jurmitglieder (scheinen) dem Vortrag zu folgen und stellen Fragen - evtl. Jury in 3 Jurys aufteilen" "nach Fachbereichen getrennte panels zur Beurteilung" "wichtig wäre die Ausgewogenheit der Jury zu gewährleisten: kein Überhang von Physikern o.ä.").

In particular the non-successful candidates for the START Programme complain that they did not receive any explanation for the rejection ("Es wäre gut, wenn abgelehnte Kandidaten eine Begründung von wenigstens ein paar Zeilen erhielten." "Man bekommt bei Ablehnung die Gutachten der Reviewer, jedoch kein Bericht oder Begründung der Jury mitgeteilt").

Two voices from the survey indicate that the composition of the jury does not favour the selection of interdisciplinary projects. ("Die Auswahl der Juroren der Start-Jury bevor- 
zugt 'Mainstream' Wissenschaft. So sind in der Biologie/Medizin 3 von 4 Juroren aus der Medizin/Krebsforschung." "Ein Vortrag vor einer nicht Fachjury von nur 10 Minuten benachteiligt schwierig zu vermittelnde Forschungsansätze, wie z.B. interdisziplinäre."). The risk that rather mainstream research is funded is also seen by a representative from a university. For this interviewee the peer review process is problematic, as the chances are high that out of four reviews at least one is written by a risk-averse reviewer who disapproves a high-risk project. ("Overambitious sollte kein Kriterium sein, nicht zu fördern. Eigentlich sollten STARTer ja auch gelegentlich inhaltlich scheitern").

The majority of involved stakeholders is content with the existing selection process of the START Programme and perceives it as mostly fair and transparent. It is uncontroversial that this kind of programme needs to rely on an international jury for the selection of grantees. With the view to fund the most excellent researchers, all stakeholders were furthermore against any kind of quota. As for similar programmes which target excellent researchers, there are multiple criticisms which can be put forward towards the selection process. It is undeniable that the final selection relies to a certain extent on the subjective decisions of a group of individuals. With a success rate of only $13 \%$ it will not be possible to do justice to all candidates.

\subsubsection{Administrative Requirements and Processes}

The survey results and the monitoring data collected by the FWF through the end-of project reports show an overwhelming positive picture of the interaction with the FWF. Almost $90 \%$ of survey participants rate the assistance of the FWF during the application procedure as more than adequate or adequate (see figure below). The satisfaction with the assistance of the FWF during funding is even higher. The monitoring data show a similar high satisfaction with the requirements and existing procedures and guidelines during the application process and implementation. (see Annex) This has been confirmed in the interviews with the START grantees where the satisfaction with the FWF was perceptible ("vorbildlich", "sehr gut, ausgezeichnet, kompetent, super", "unheimlich informiert mit dem Blick auf die richtigen Dinge, sehr professionell", "really great organisation").

Although the amount of funding is usually seen as too tight and too low, the overall majority of survey respondents rate the level and length of funding as adequate or even as 'more than adequate'. 
Figure 12: $\quad$ Rating on different aspects of FWF's assistance (START grantees)

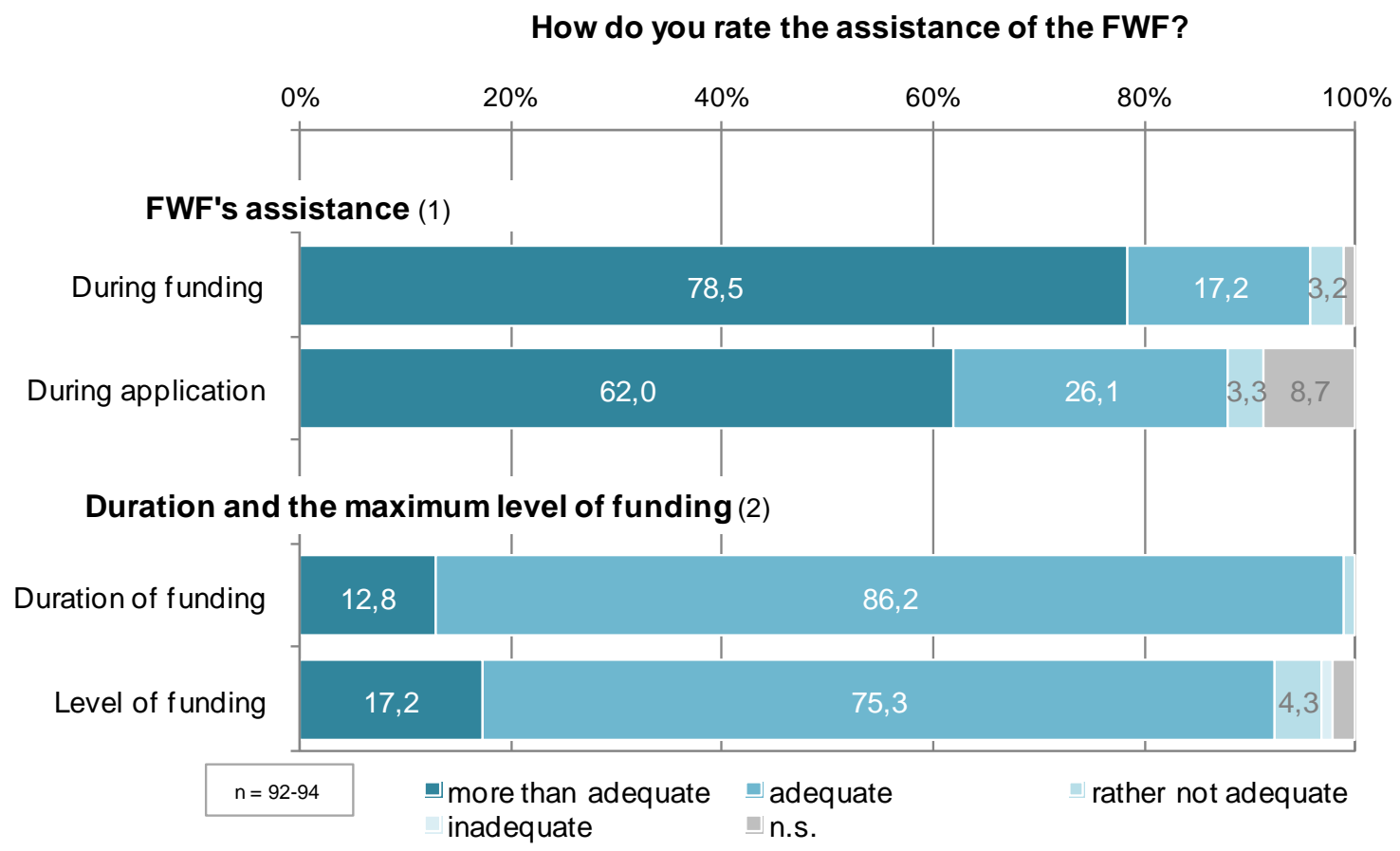

(1) Question asked: "How do you rate the assistance of the FWF?"

(2) Question asked: "How do you rate the duration and the maximum level of the START funding as measured by the requirements of your own research area?"

The numerous annotations in the final reports, the case studies and the survey reveal a high degree of satisfaction with the FWF as a funding organisation and the design and management of the START Programme: "Die Flexibilität des Programms und die Administration durch den FWF bilden eine hervorragende Basis, die wenig Platz für Verbesserungen lässt." "Exzellente Unterstützung sowohl bei der Antragstellung als auch in der Ausführungsphase, flexibel, zielorientiert und sehr supportiv." One interviewee recommended preparing a standard format of the contract in English for START grantees from abroad.

This flexibility is highlighted in the interviews with the START grantee, both, with view to shifting costs and the possibility to extend the project cost-neutrally which turns out to be very advantageous concerning reconciliation issues ("Das war sehr wichtig, da zwei Mitarbeiter und ich selbst Kinder bekommen haben.").

Also the jury members underline the professionalism of the project management and the support they receive during the application and interview process. 


\subsection{Outputs, Outcomes and Impacts}

The following chapter describes the achievements of the START Programme. The main focus of the analysis is on the START grantees themselves, especially their scientific performance, their career development and their institutional integration into the (Austrian) research system. Furthermore, the effects on the indirect beneficiaries, such as young researchers in START project groups, will also be investigated.

\subsubsection{Direct Effects on the START Grantees}

The expectations of the START grantees towards the START Programme 21 have been met completely or to a high degree, in almost all aspects. Over $90 \%$ of the START grantees who answered the survey see their initial expectations broadly met with regards to research aspects ('freedom to concentrate on research'; 'opportunities to work on unconventional research questions') and with regards to opportunities to build up an own working group and positive effects on the career.

The expectations in the categories 'gain management experience' and 'gain a permanent position in academia' are slightly less fulfilled; however, the survey participants had also far fewer expectations towards these two aspects (see Figure 2 in chapter 3.1.1). The goal attainment on these aspects can therefore be seen as satisfactory.

21 The motives of an application into the START Programme are discussed in chapter 3.1.1 
Figure 13: $\quad$ Degree to which initial expectations towards the START Programme were met (START grantees)

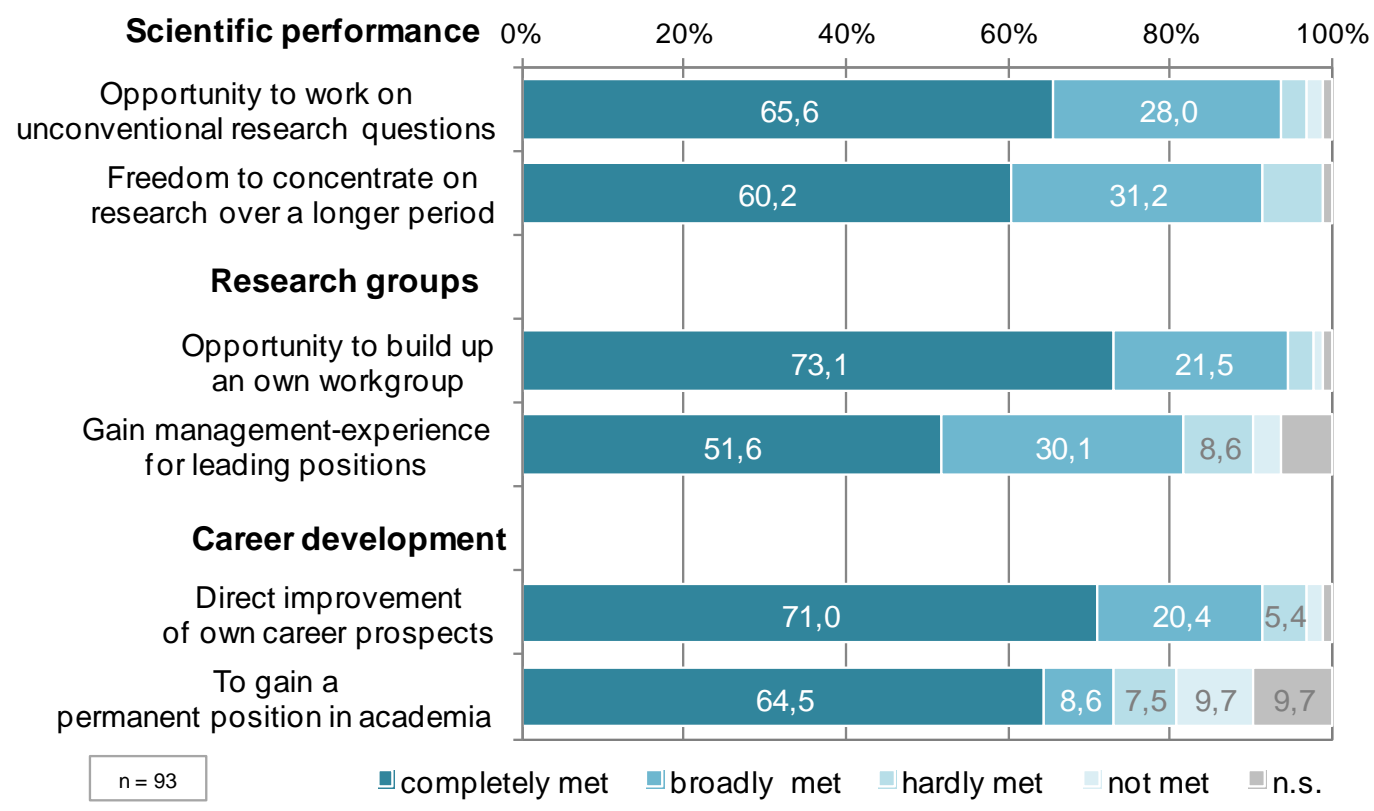

This high degree of fulfilled expectations is a promising starting point for investigating the effects and impacts of the START Programme.

\subsubsection{Research Output}

One of the main objectives of the START Programme is to fund the most promising young researchers by giving them the financial resources and time to pursue a research project and excel in their research discipline. The success of research activities is typically measured by their publication outputs, even if the limitations of these quantitative indicators are well-known. Particularly the used bibliometric database, the Scopus database, covers mainly journal articles, but its coverage of books and conference proceedings is only unsystematical. As a result, the coverage of publications is not equally good across all research disciplines and quite poor for some of the social sciences and especially the humanities. These limitations have been mitigated in this study by the creation of statistical twins, i.e. the scientific performance of researchers is compared to researchers in the same research discipline. The bibliometric analysis is furthermore completed by evidence of the surveys and the case studies. 
For the purpose of this study, we use five bibliometric indicators as proxy to assess the scientific performance:

- number of publications,

- citation rate,

- number of publications written with co-authors,

- number of organisations per co-publication,

- number of countries with which co-publications are written.

First, the changes in the scientific performance of the START grantees over time is analysed, i.e. before, during and after the START funding. Secondly, the group of START grantees is compared to the control group in the different time periods.

\section{Scientific performance of the START grantees: before, during and after the START funding}

The scientific performance of the START grantees has increased continuously for nearly all indicators, as can be seen in the following figures.

As START grantees progress in their research career, they publish more in absolute numbers, are increasingly active in publishing together with other researchers and with other research institutions than the researchers in the control group. They are also well connected to the international research community with an increasing amount of publications written with institutions outside Austria.

Figure 14: Average number of publications Figure 15: Average citation rate per year

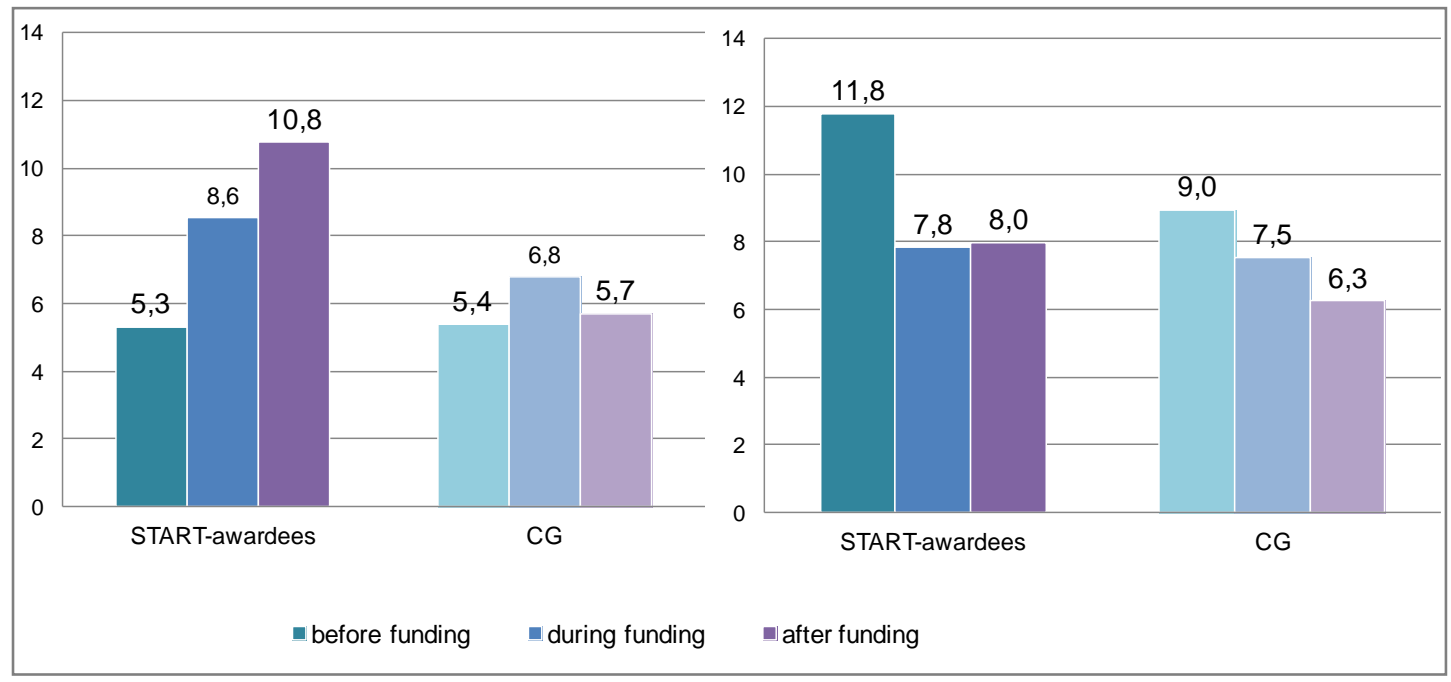


Figure 16: $\quad$ Co-publications, collaborating organisations and countries
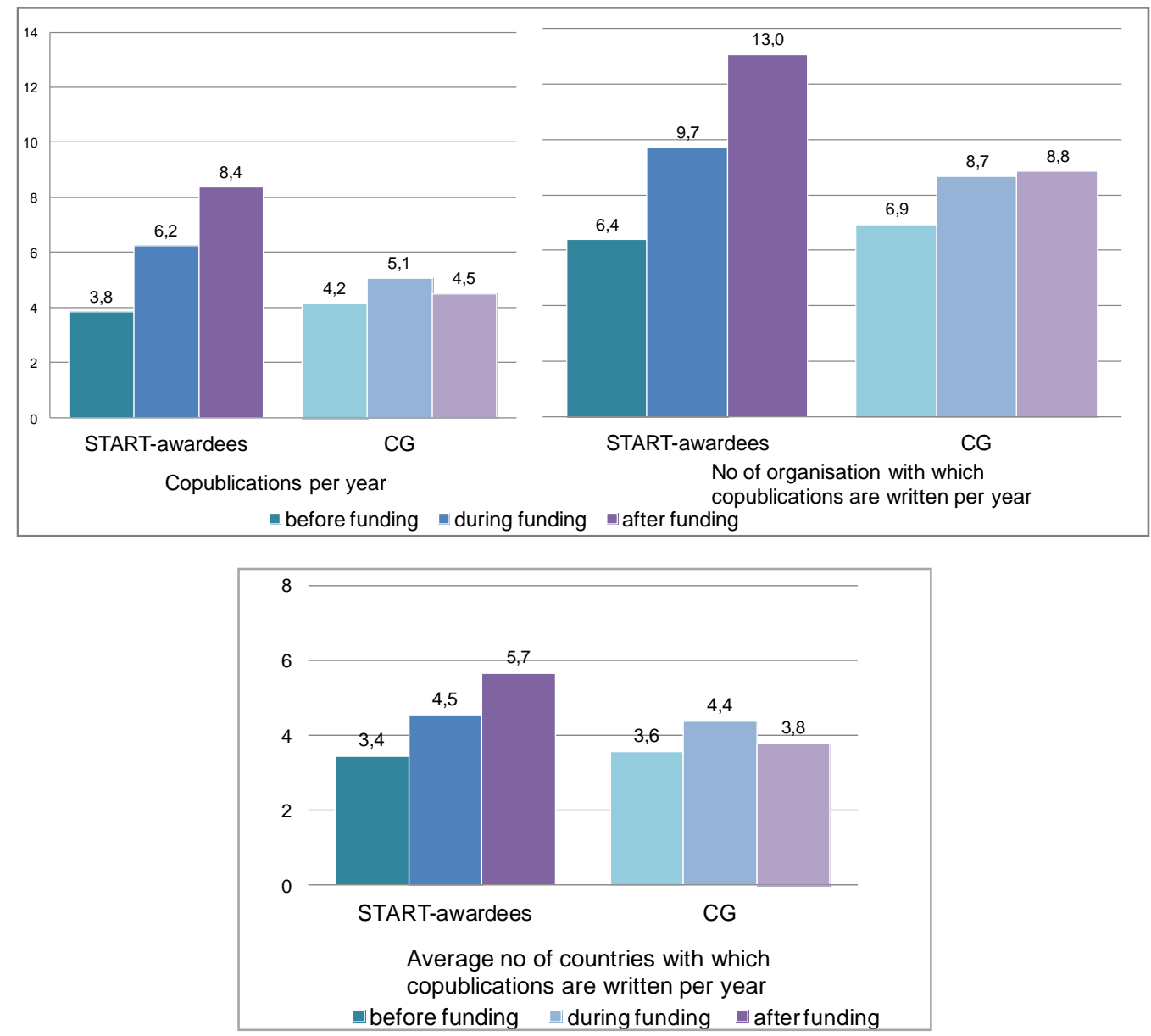

At first sight, the citation rate shows a slightly different trend than the other indicators. It would, however, be premature to conclude from the decreasing citation rate that there is a decrease in performance. Here scaling effects might enter into play: When the amount of publications increases, but the amount of high-quoted publications remains constant (which is often the case), the average citation rate decreases.

In another reading, the downshift of the citation rate during and after the START funding could also be a direct effect of the START funding: namely the result of a newly gained scope for testing new and unconventional research fields. Evidence from the survey and the case studies lead to the hypothesis that some START grantees have ventured a re-orientation of their research towards new or more unconventional research fields for which he/she is not (yet) visible in the research community. In the interviews with the START grantees it was highlighted that the length and the amount of funding provides a certain security and allows taking time ("Es war ein nicht zu unterschätzendes Privileg zu sagen 'mach ma's g'scheit'. Dadurch habe ich eine Ent- 
spanntheit entwickelt, Dingen die nötige Zeit zu geben. [...] Ich konnte in Ruhe tüfteln an der eigenen Vorstellung von Perfektion.") This argumentation is supported by the survey of START grantees, in which $75 \%$ of the respondents state that the START Programme had been conducive to accessing new fields of research (see Figure 17 below). The slight rise of the citation rate in the period after the START funding can be seen as an indicator for a promising outlook with regard to future scientific performance of the former START grantees, once they have settled in their new research field.22

Furthermore, the citation rate allows conclusions on the selection process: The high citation rate of 11.8 before the START funding indicates that researchers with an outstanding scientific performance have been selected. The goal of the START Programme to fund outstanding researchers in Austria can be seen as achieved.

\section{Scientific performance of the START grantees compared to the control group}

The comparison with the control group shows that the START grantees perform better throughout for all indicators and also during the different periods analysed (see Figure 14, Figure 15 and Figure 16 above). The fact that the performance of the control group decreases for all indicators except the cooperation with organisations for the period "after the funding", while the START grantees' performance is further increasing, suggests that the START Programme contributes to boosting the scientific performance of the grantees, especially in the medium run.23

The findings from the survey of START grantees support the argumentation that the START Programme has contributed to strengthening the grantees' scientific performance. Almost all survey respondents state that the START Programme has been conducive for their publication output and the profiling in the respective research area. More than $60 \%$ indicate that the START Programme was conducive to receiving further (academic) awards.

22 Earlier studies on citation rates of FWF funded programmes / project come to a similar conclustion. See: FWF (2009): A contest between nations; or how far is Austrian research behind that of the world leaders.

23 The differences between the groups are statistically significant for all indicators (calculated for the period "after funding"), except for the citation rate. The Mann-Whitney U Test has been used to calculate the similarities between the two groups. 
Figure 17: $\quad$ Effects of the START project on the performance in the area of research (START grantees)

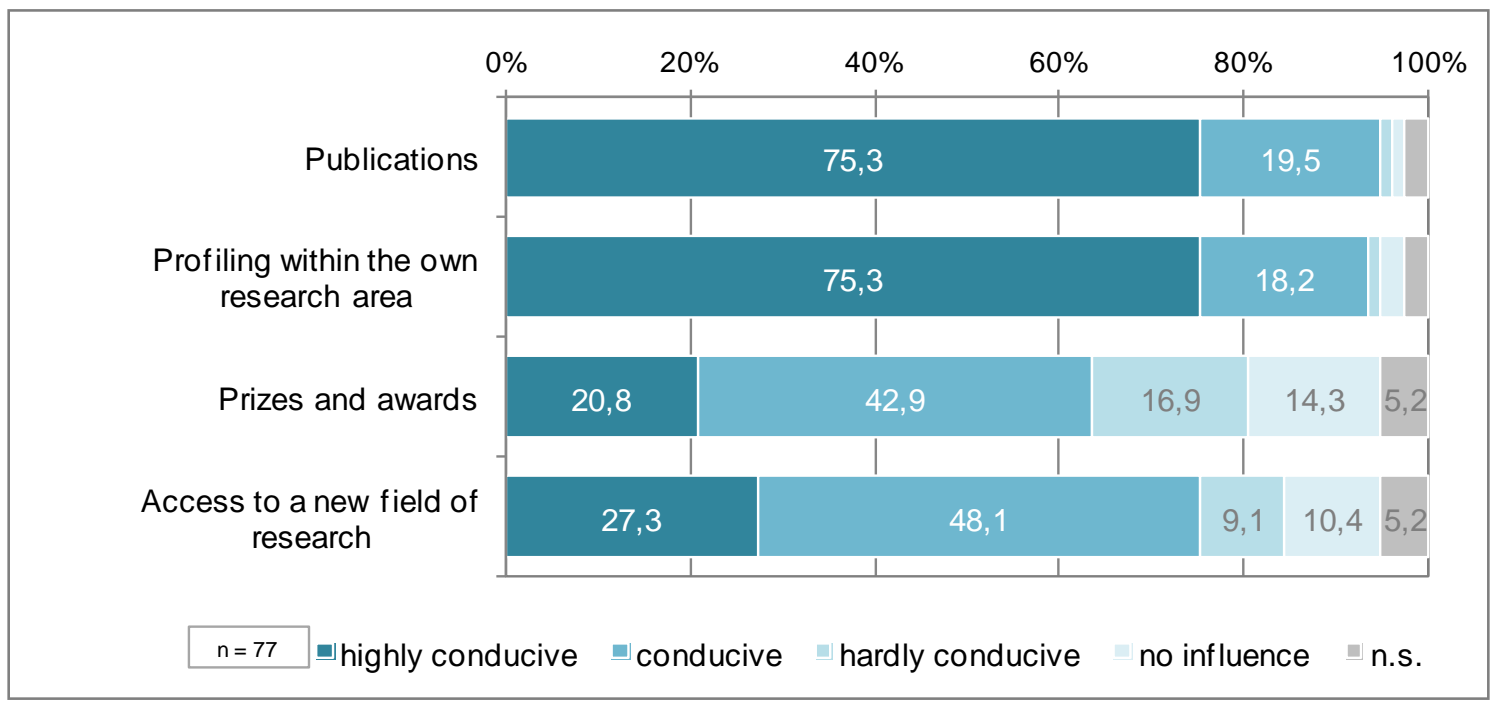

Question asked: "How has the START-project affected your performance in the following areas?"

When asking the candidates to the START Programme (CS) whether the missing START grant has impacted on their scientific performance, $70 \%$ of the respondents state that it has hindered their publication performance; almost $60 \%$ state that the START Programme would have been beneficial for the profiling within the own research area, and $50 \%$ state that it has affected the access to new fields of research negatively.

In conclusion, the bibliometric analysis and the survey results show that the START Programme selects the (most) qualified individuals for the programme. Furthermore, the analysis suggests that it has considerable positive effects on the scientific performance of the researchers receiving START funding, during the funding but also for their future scientific performance

\section{Perceived added value of the START Programme}

All START grantees responding to the survey are of the opinion that it would not have been possible to carry out the research planned in the START project without the funding or at least not to the full extent. The high added value of the START Programme is also reflected in the answers of the CS-group, which state to $64 \%$ that they have implemented their research planned for the START project only to a limited extent (see figure below). 
Figure 18: $\quad$ Possibility to conduct planned research without START funding (Start grantee and comparison group)

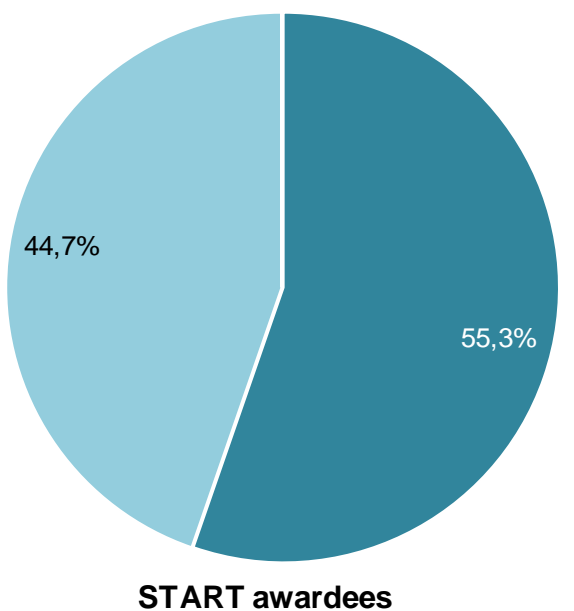

START awardees

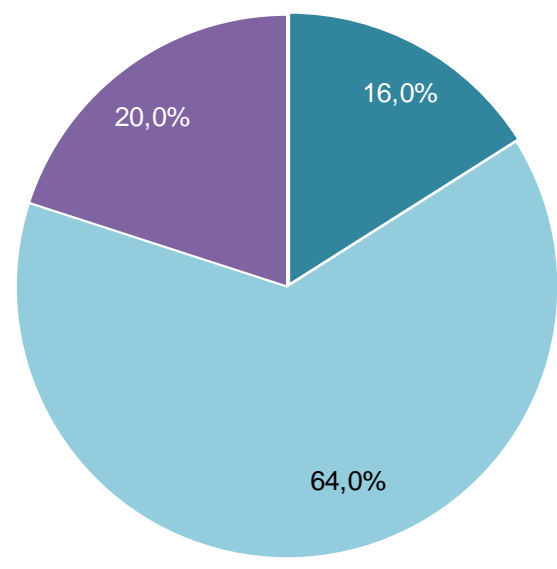

Comparison group

$\square$ No $\square$ Yes, but only to a limited extent $\square$ Yes, completely

Question to START grantees: "Would you have been able to conduct the research planned?" Question to comparison group (CS): "Have you been able to conduct the research planned for the START project even without the START funding?"

In most cases the CS funded their research projects by a combination of several funding sources. The main funding sources were FWF grants (Einzelprojekte) or basic funds available at the institution of their workplace. 
Figure 19: $\quad$ Funding used by comparison group to realise research project orignally planned as a START project (comparison group)

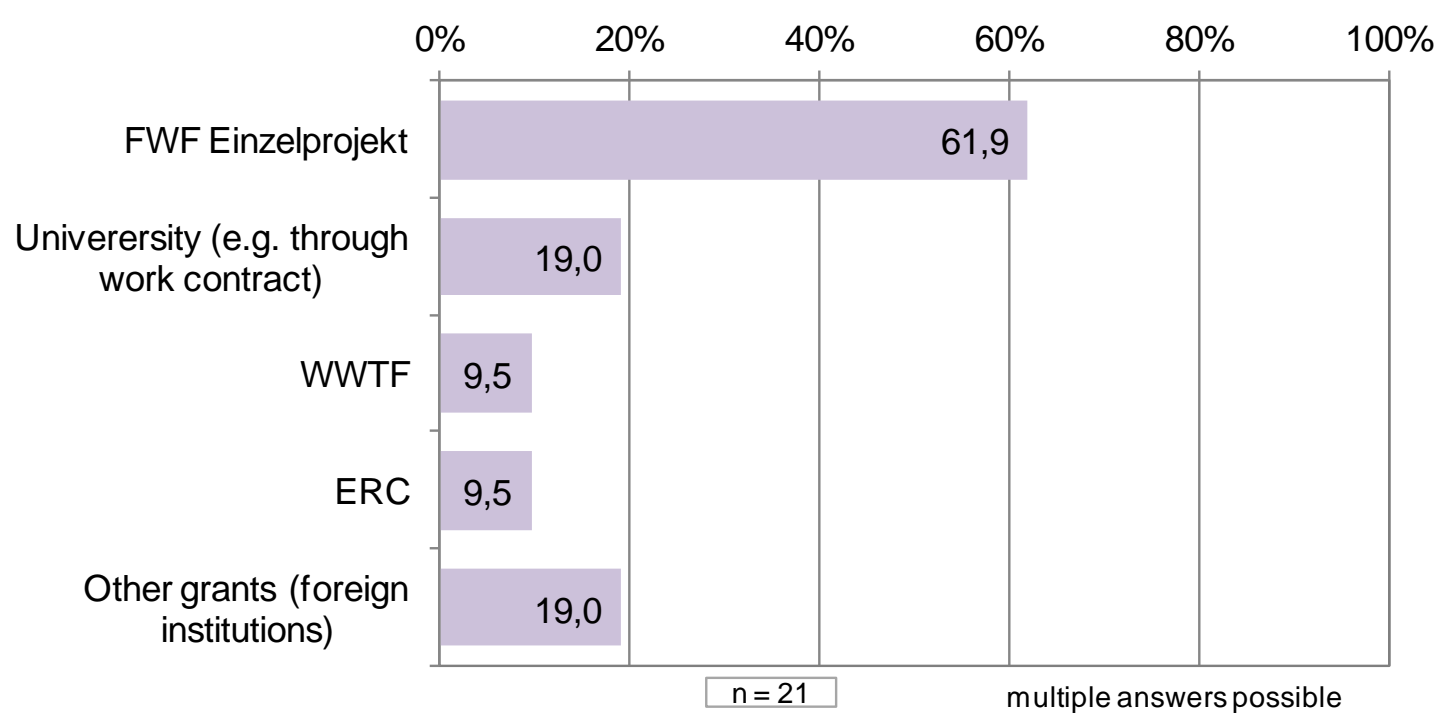

For those $20 \%$ who stated that they have been able to conduct the research as planned without the START funding, two survey participants financed it with an ERC grant, another with a WWTF-grant. The two remaining financed their research by combining different funding sources or received funding from foreign institutions. Thus, without public funding it seems to be nearly impossible to pursue their research ideas.

In the case studies the interviewed START grantees underlined that START offered them the possibility to achieve outstanding results and access to A-level journals ("man wird besser, kompetitiver und hat bessere Publikationen"). An important aspect in this context is that these research results are often based on the development of new methods within the projects. 


\subsubsection{Outputs beyond Scientific Publications}

Beside scientific performance, the analysis shows that there is a variety of approaches on how the research results are used and accordingly far more impacts than purely research-related ones. These non-research outputs are quite divers, reaching from teaching to the management of research projects and groups, and are of further use for the private sector or society in general.

\section{Scientific, commercial and societal utilisation of research results}

The START projects were especially conducive for areas that are close to research, such as project acquisition and establishment of cooperation with about $80 \%$ of respondents indicating a respective effect (see Figure 20 and in particular Figure 21).

Further $40 \%$ of the survey respondents used the results of the START project for teaching purposes which is also stated in the final reports which were examined ("Research pursued within the START project also laid a foundation for teaching courses." "Many of the new results are directly used in courses on [...] to motivate students and to attract the best students to the exciting field of [...].").

START grantees are also active in the commercial or societal utilisation of the research results. $17 \%$ of survey respondents have used the research results of the START project to cooperate with industry, $12 \%$ state to have registered patents (figure below). This is confirmed in final project reports ("The research work of the START project led to several projects with industry.")

Seen from a marketing perspective, the active communication of research results outside scientific channels (e.g. newspaper, radio, TV, but also social media) can be highlighted: $64 \%$ of the respondents state that they have disseminated their research results in the mass media (figure below). One START grantee also reports on public relations activities which address young high school students in order to attract them to research in general and to the specific field in particular. 
Figure 20: $\quad$ Use of START project results (START grantees)

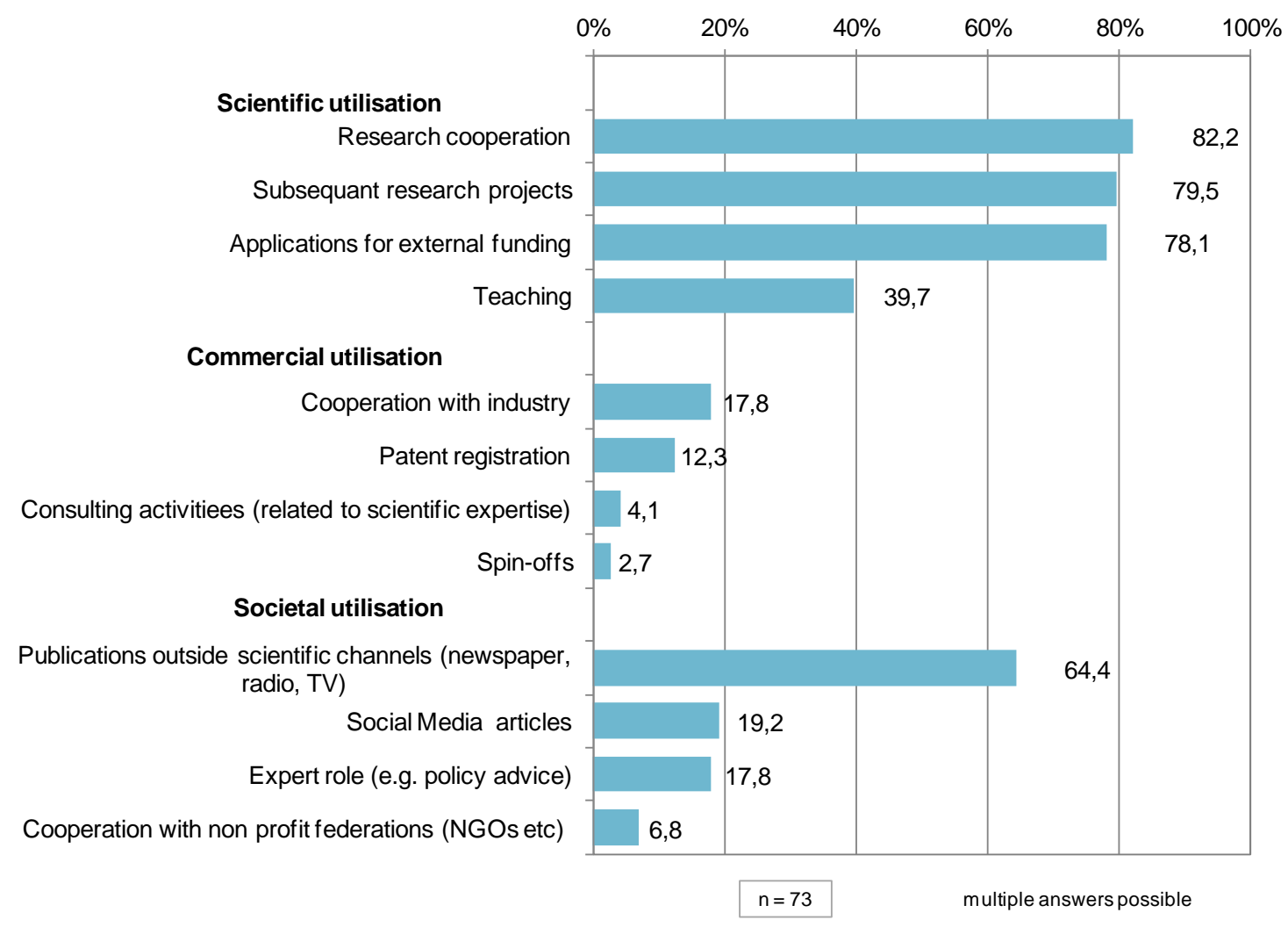

Qustion asked: "How did you use the results of the START project?

\section{Research management and follow-up project activities}

Almost $90 \%$ of the survey respondents indicated that the START project has improved their performance in the field of research management, as can be seen in the figure below.

According to the survey, the START Programme was highly conducive to the development of research cooperations (see figure below). This was also emphasised by the START awardees interviewed and in final project reports. All interviewed START grantees reported on several new projects based on START and new cooperation: "Ohne START gäbe es kein (..) Netzwerk", "Auf unserem Campus gibt es interdisziplinäre Forschungsplattformen - START hat mir geholfen in Verhandlungen für eine Forschungsplattform zu treten." In the final reports one can read: "This translational aspect of our research led to new collaborations with our university as well as with researchers from abroad", "Numerous international and local collaborations have developed on the basis of the START project" 
The cooperation with other (leading) researchers is often the result of visits or international conferences ("Based on results that have come out of the START project there have been more than 30 invitations to speak at international conferences and workshops. "). The added value of attaining A-level conferences with a view to further cooperation opportunities has been highlighted. The START grantees also (co-)organised international meetings which can be derived from the final reports.

Figure 21: $\quad$ Effects of the START project on the performance in the area of research management (START grantees)

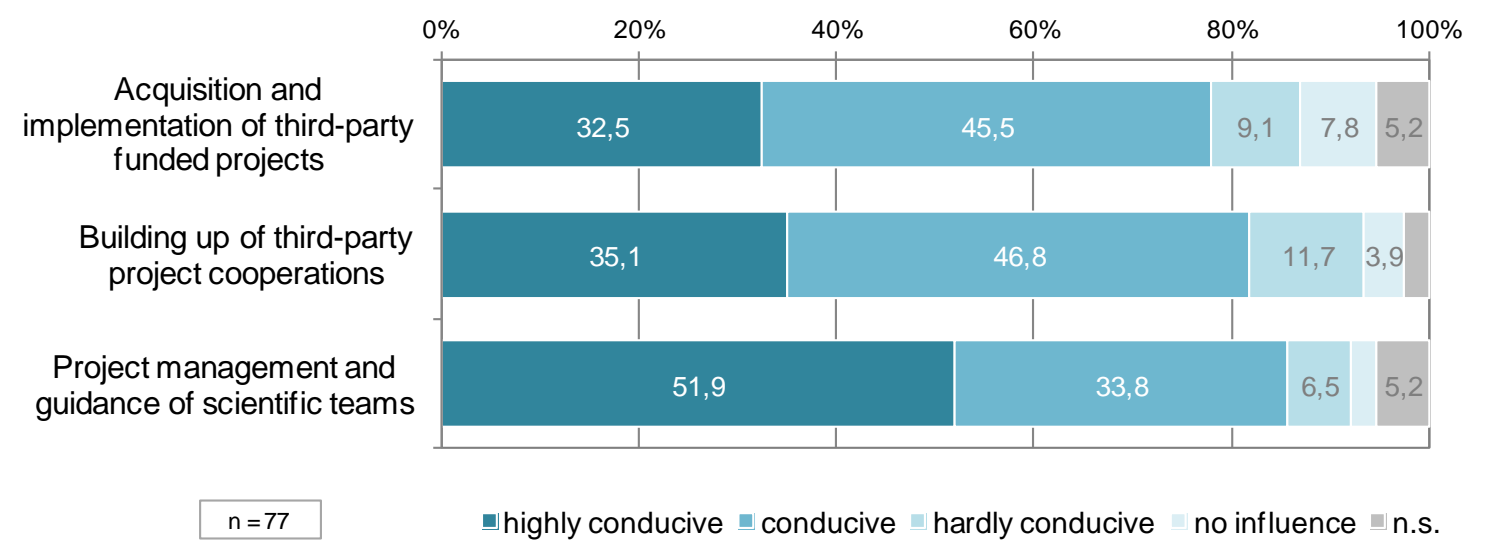

Question asked: "How has the START project affected your performance in the following areas?"

Especially the aspect related to the management of research groups must be highlighted. More than half of the survey participants indicate that START has strengthened their competencies in the field of project management. This is confirmed by the interviewed START grantees: "Man hat seine eigenen Doktoranden und ist für diese verantwortlich." "Man hat große Verantwortung für den Nachwuchs." These statements must be valued in particular, especially with regard to the low initial expectations of the START grantees towards the aspect of gaining knowledge and know-how of managing teams of researchers (see Figure 2 in chapter 3.1.1.1.).

\section{Visibility of the programme}

The survey participants have been asked to assess the visibility of the START Programme on three different levels: the funded researchers, the FWF and the Austrian research system. The researchers of all three surveyed groups come to a similar positive assessment (see figure below) with regards to the visibility that the START Programme creates within the research community. As foreseen, the START grantees rate 
the visibility and the effects on the reputation of the START Programme slightly higher than the control groups, the difference between the two groups 24 is however only statistically significant for the last two categories of the figure below ("attractiveness of Austria as research location" and "convergence"). 25 The fact that almost $80 \%$ of the control group respondents knows the START Programme is another indicator for the good visibility of the START Programme in Austria.

Figure 22: $\quad$ Assessment of the visibility and reputation of the START Programme

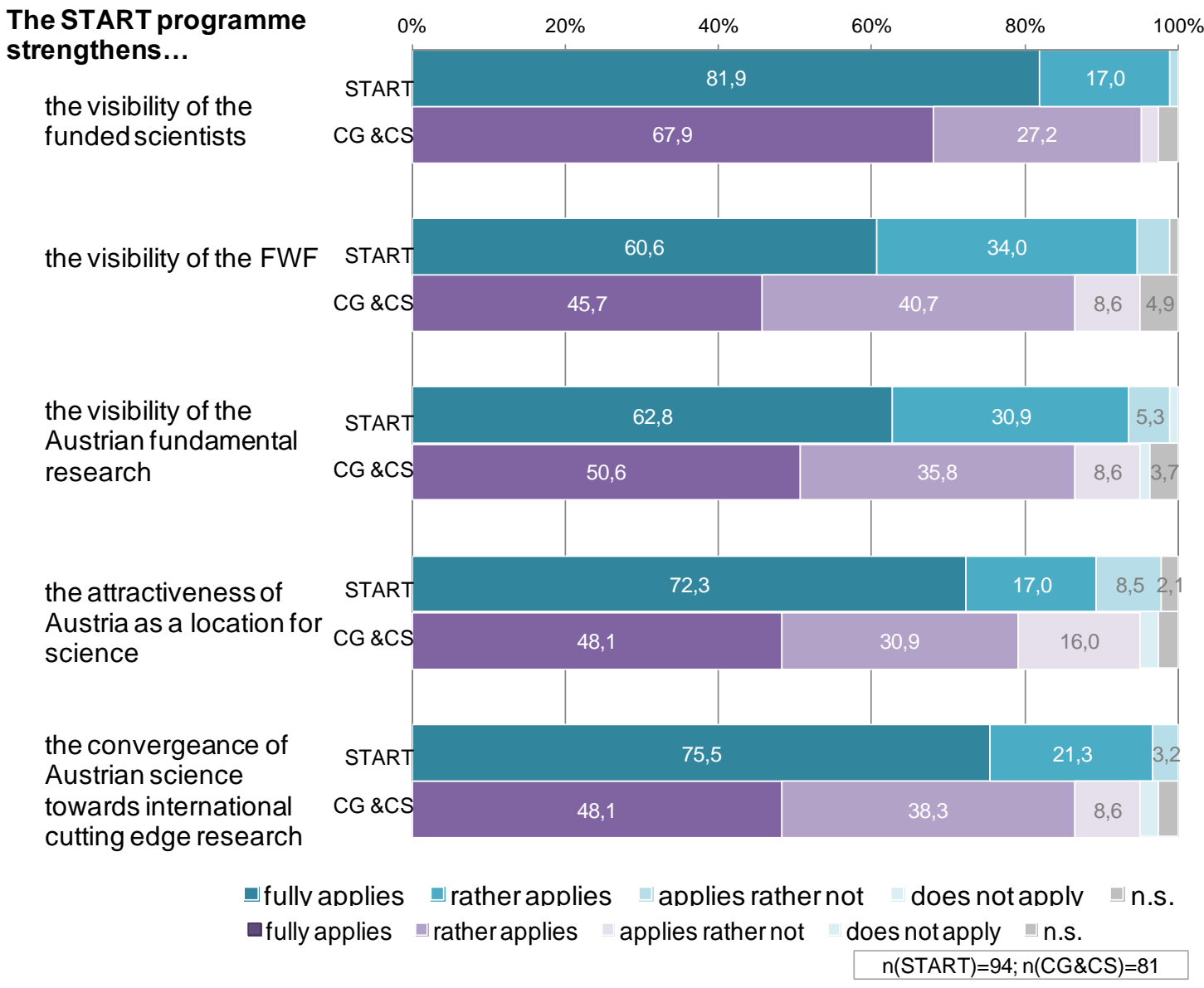

In the case studies the START grantees reported of the added value of START concerning their enhanced visibility mainly within the institution and the research community

24 The answers of the control group and the CS show no statistical difference (Mann-Whitney$\mathrm{U}$-Test), significance level $\mathrm{p}<0,05$, and it was chosen to aggregate them for simplification purposes.

25 Mann-Whitney-U Test, $\mathrm{p}<0,01$. 
("Ohne START gäbe es kein Netzwerk. Ich hätte das nicht mit Oxford machen können." "Ich bekam dadurch Angebote für Professuren aus England und Deutschland.").

Not surprisingly, the surveyed ERC grantees attribute to the ERC grant a higher international visibility and reputation. This is due to the fact that START is a national programme.

\subsubsection{Career Development of the START Grantees}

The START Programme does not only aim for the general promotion of research excellence, but also for the career advancement of the promoted individuals. More specifically, the START Programme aims at a 'permanent integration' of the grand holders into the (Austrian) research system. In the context of this evaluation, "permanent integration" is operationalised as a permanent work contract in a research organisation, particularly a university. This often correlates with a full professorship. Thus, in the following sections we investigate in detail whether the successful participation in the START Programme had such positive career impacts, especially compared to the two control groups.

\subsubsection{Employment Sectors}

The study results show that all START grantees that have responded to the survey and have (already) finalised their START project, remain in the research system.

The majority of former START grantees remain in the institution in which he/she was employed for the START project (57.8\%). More than one third of the respondents (35.6\%), however, have been employed by a research institution abroad after the end of the START project.26 Less than $5 \%$ have chosen an Austrian research institution different from their START project institution.

However, the employment patterns of the two control groups are rather similar and show no statistical difference to the group of START grantees27. Just like the START grantees, most survey respondents from CG and CS work today as researchers in a research institution, either in Austria or abroad.

26 For the comparison of mobility pattern in different EU countries see: Conchi, S., Michels, C.: (2014): Scientific mobility. An Analysis of Germany, Austria, France and Great Britain. Fraunhofer ISI Discussion Paper.

27 Fisher's Test, significance level $p<0,05$ 
Figure 23: $\quad$ Sector of employment of surveyed researchers

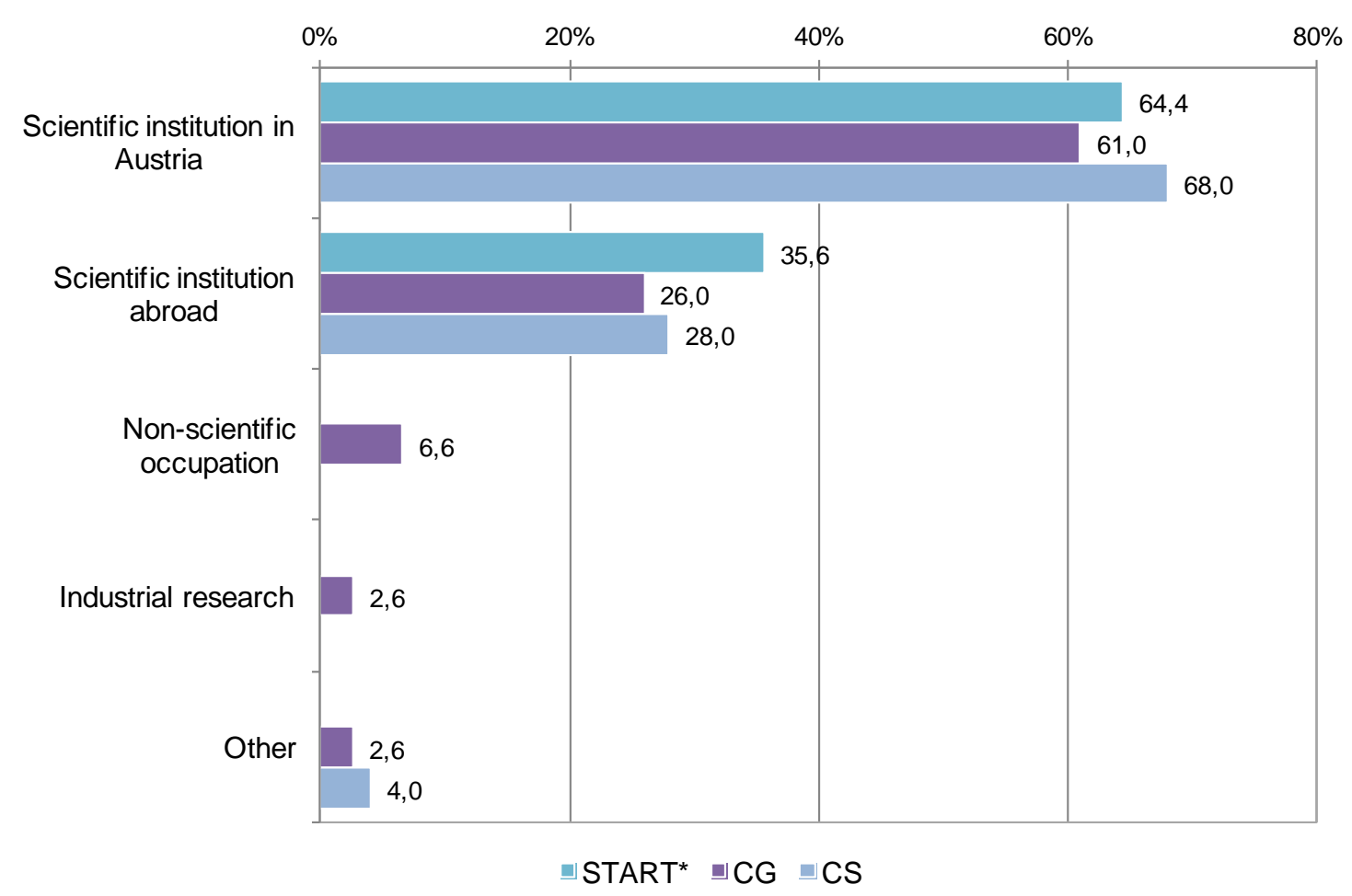

Question asked to the START grantees: Where have you been employed after your START project?

Question asked to the control and comparison groups: Where are you currently employed?

For the researchers that left Austria, the reasons for joining a foreign research institution are quite similar in all three surveyed groups. The main motivation is an attractive job offer from abroad. The second main reason for the START grantees is the lack of an appropriate position in Austria. This is also one of the main reasons for the two control groups. Furthermore, both control groups also state as a motive for leaving Austria "better long-term career prospects" and "better conditions for researchers". These last two aspects are quoted less frequently by the START grantees. The answer "no choice due to contractual issues (Kettenvertragsregelung)" is with $10-15 \%$ only a minor reason for leaving Austria.

Of the four START grantees investigated in the framework of the case studies, who had already finished their START projects, two are employed in a research institution in Austria, one moved to Germany. All hold full professorship positions. The reason for the START grantee to move abroad was a very attractive job offer (permanent research professorship with reduced teaching load). The fourth START grantee is currently in the process of returning to Austria from the USA where he held a Visiting Scholar and Honorary Fulbright Grantee. The START grantees, who have not finished 
their START project yet, plan to stay in their institution as they have already gained a permanent position or such a position has been promised.

The reception of the START grant is often seen as the decisive element to remain in Austria. Two interviewees report that without START they would have left the country ("Ich hätte das Land verlassen, hatte meine Koffer gepackt." "Without START I would have been forced to leave the country."), one came back from the USA because of START ("Ich habe das post-doc in Stanford abgebrochen wegen START.")

\section{Excursus: Factors to gain a permanent position in Austrian research system}

When asking the control group and comparison group about important factors to gain a permanent position in academia in Austria, unsurprisingly, aspects of scientific performance rank at the top, concretely aspects like 'publications' and 'profiling within the own research area', 'research in a well-established research area', 'international experience'. Work on unconventional research questions is however assessed as less important by two-thirds of the survey respondents.

In the field of research management, 'experience of the acquisition and the implementation of third party funds' is seen as important. Furthermore, around two-thirds of the respondents see 'experience of managing a research group' as an important factor for a career in research.

Other important employment factors in the research system in Austria are: Experience of third-party project cooperation, integration in the Austrian research network; projects and grants of the FWF, teaching experience.

The START Programme addresses all these factors successfully, as discussed in the preceding chapters.

\subsubsection{Positions held by the START Grantees}

When investigating the career effects, we firstly looked at the highest positions the START grantees achieved during their career. As it is shown in Figure 24, the majority of START grantees are currently (March 2015) holding or have held a professorship position. For this study three different professorships have been distinguished, based on the former and recent Austrian research system: full professorship (Universitätsoder FH-Professorln); Associate Professor (Assozierter(e) Professorln, ehem. DozentIn); Assistant professor (Assistenzprofessorln). In this respect, however, the START grantees do not differ from the two non-funded groups. The control group and the candidates for the START Programme show a similar pattern with regards to job positions. 
Out of the interviewed START grantees, five currently hold a professorship, two are directors of an institute and one is to negotiate a permanent position in the host university in autumn 2015.

Figure 24: $\quad$ Highest position in the research system reached to date*

Professorship

(all positions)

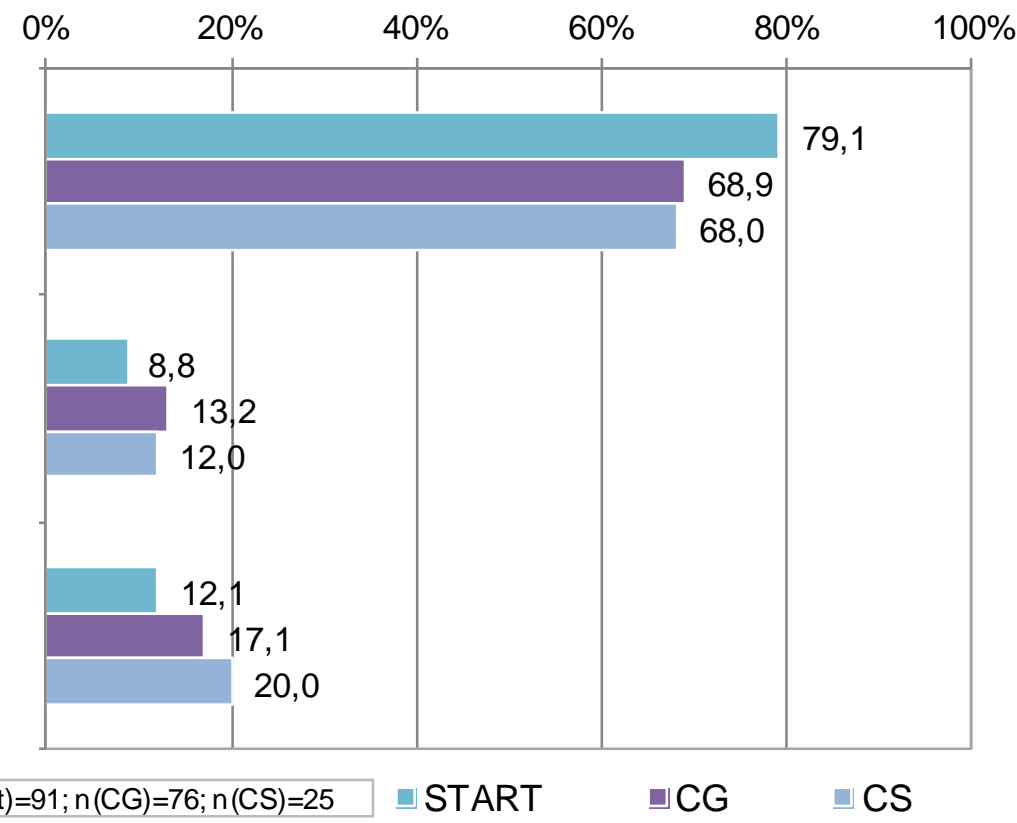

'* The difference between the three groups is not statistically significant Significance level: (Fishers-exact test; $p>0,05$ )

Other non-academic positions have been excluded from the graphic, for clarity purposes.

When looking at the nature of the contract (permanent vs. temporary contract) as an indicator of a successful and sustainable integration into the research system, survey results draw a positive picture, with $80 \%$ of START grantees responding to the survey holding a permanent work contract after the completion of the START project. In comparison, only $64 \%$ of the surveyed START grantees held a permanent contract during the START project. Before the START Programme, this was the case for only $28 \%$. 
Figure 25: $\quad$ Permanent vs. temporary work contract (START grantees)

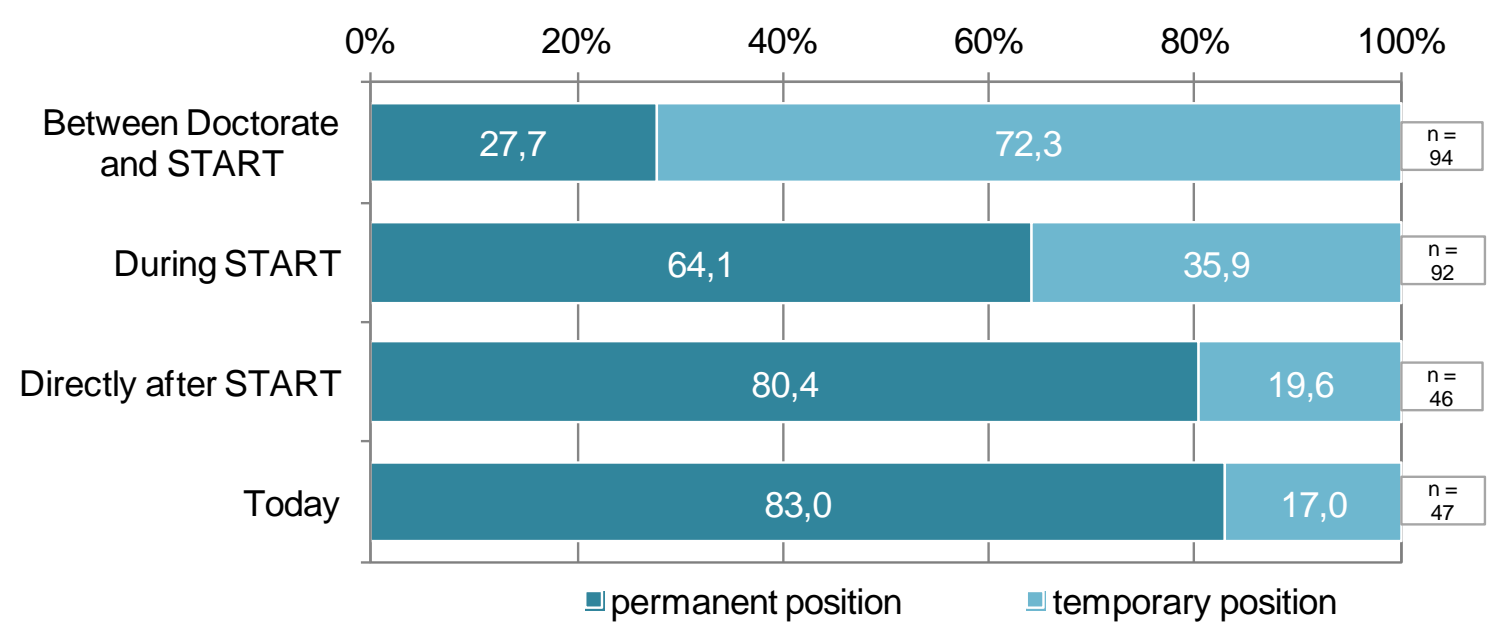

Question asked: "Which type of work contract did you hold during the following career phases?"

Until 2007 a prerequisite for the START Programme was that the applicant had an existing work contract. Since then, the START Programme can be used to finance the position of the START grantee. Out of the START grantees after 2006, only $17 \%$ had a permanent contract before the START Programme compared to $38 \%$ of START grantees before 2006. During the START project, already $57 \%$ of the START grantees funded after 2006 had a permanent contract. It seems that the START Programme goes along with a permanent position for more than half of the START grantees in recent years. In the interviews, the younger START grantees with a project at universities report that they have gained temporary professorship positions with a view to gaining a permanent position after START ("Ich habe eine Drei-Jahres-Professur mit der Aussicht auf eine längerfristige Professur.").

\subsubsection{Pace of the Career Development}

In order to assess whether the START Programme influenced the pace of career development, the different groups surveyed were asked for their year of $\mathrm{PhD}$ graduation and the year of appointment to a professorship position. The 'career pace' is here measured as the difference between both years.

On average, the START grantees receive funding for 7.5 years after having completed their doctoral degree. 
It has to be concluded from the survey results that the START Programme has no influence on the pace towards a professorship.28 START grantees do not get appointed to a professorship earlier than the control group or candidates for the START Programme.29 One explanation is put forward by a jury member: "People who did not receive START will look at getting a permanent position earlier, they are under higher pressure to get it, whereas awardees can take their time". Around $80 \% 30$ of all surveyed researchers are appointed as professor between their fifth and the $15^{\text {th }}$ year after their doctoral graduation. Since 2006, researchers have been appointed earlier to a professorship position than START awardees who have received the funding before 2006 (valid for START grantees as well as control group) ${ }^{31}$. This might be related to changes in the research system, such as the introduction of tenure track positions.

Although from a time perspective the START Programme does not speed up the research career, the START Programme is however perceived as a motor for the research career development by the START grantees. Almost all of the responding START grantees $(97.4 \%)$ are of the opinion that START has strengthened their career prospects.

Furthermore, $60 \%$ of the responding START grantees are convinced that they would not have reached their current position without the START Programme. This is also confirmed in the case studies ("It is a kind of policy in the field. With START you get a permanent position." "START hat einen sehr großen Anteil daran, dass ich jetzt Direktor bin." "Riesenschritt in die richtige Richtung").

In comparison, the ERC grantees assess the effect of their ERC grant as slightly less dominant. Almost half of the respondents think that they would have reached their current position also without the ERC grant. The same trend can be seen in the group of the non-successful applicants: one third think that the START Programme would have speeded up their career, compared to half of the respondents who do not expect a faster career development from participating in the START Programme.

28 However, this result has to be interpreted with caution, as it is based on a relatively small number of survey respondents for all three groups: $n($ Start $)=64 ; n(C G)=41 ; n(C S)=17$

29 The comparison between the three surveyed groups shows no statistical significant difference. (Significance level 0,5, T-Test: 0,421)

$3086 \%$ of START grantees are appointed to a professorship in this timeframe, while it is $78 \%$ for the control group and $82 \%$ in the comparison group.

31 Perason-Korrelation index for the START grantees is $-0,705$; for the CG $-0,556$ 
Figure 26: $\quad$ Effects of the START/ERC grant on the career (START grantees and comparison group)

START grantees: Current position would have been achieved without START

ERC grantees: Current position would have been achieved without ERC

CS: Current position would have been achieved earlier with START

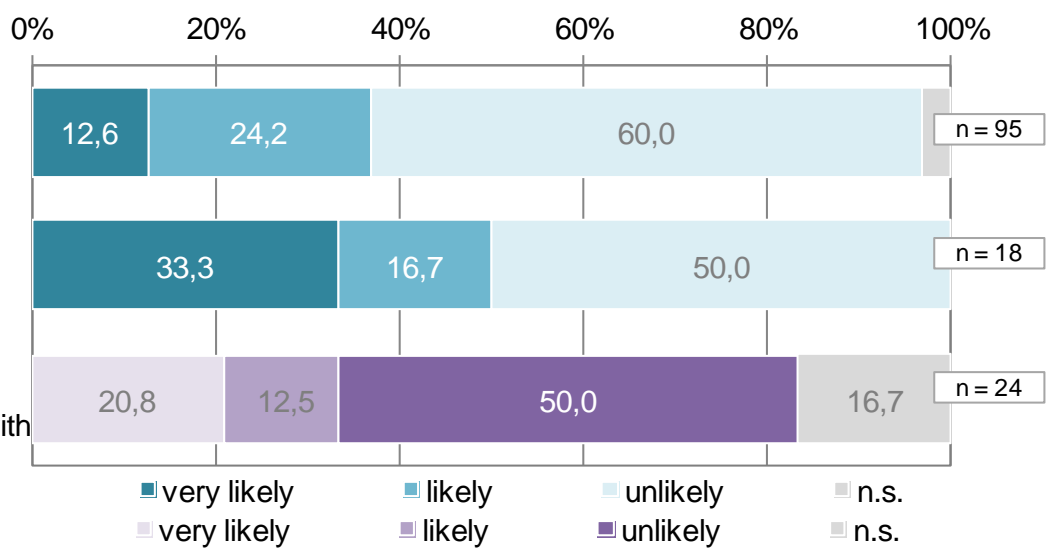

Question asked: "How has START / ERC funding affected your current position?"

\subsubsection{Interaction with the Host Institution}

As almost $60 \%$ of former START grantees remain within the institution in which the START project has been carried out, the question of the interaction of the START grantee with his/her research institution is of particular interest, especially when it comes to the negotiation related to the post START phase.

The majority of START grantees see a positive effect of the START Programme with regard to the negotiation position vis-à-vis their research organisation as to the shaping of research conditions. This empowerment is attested in the case studies, too ("Durch START hat man eine gute Position.", "START ermöglicht Zugang zu Rektoraten."). One survey respondent criticises the lack of commitment and assistance by the host institution towards START grantees and misses a formal negotiation procedure between the START grantee and the host institution, as it is the case for ERC grantees. 
Figure 27: $\quad$ Effect of the START Programme/ERC grant on the negotiation position towards the host institution (START/ERC grantees)

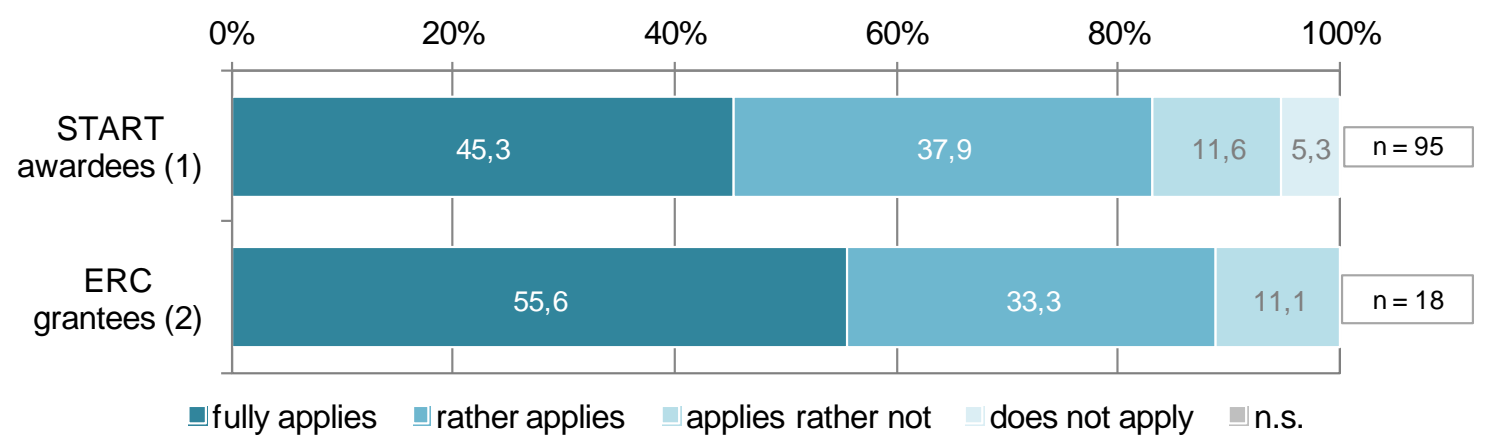

(1) Question asked: "The START Programme strengthens the negotiating position of the START grantees towards their research institution regarding the shaping of the research conditions."

(2) Question asked: "The ERC-Grant strengthens the negotiating position of the ERC grantees towards their research institution regarding the shaping of the research conditions."

As the START survey group encompasses also ERC-grantees, the ERC-group received an additional question (see figure above). It can be seen that ERC grantees assess the positive effect of an ERC grant on the negotiation power towards the host institution even higher. This might be due to the fact that ERC grants always include overhead costs, from which the host institution benefits. The fact that overhead costs are not foreseen in the START Programme was also discussed in the interview with host institutions. In one interview it was highlighted that the costs for providing START grantees with adequate framework conditions are not to be underestimated: "Einen weiteren STARTer könnten wir uns zurzeit nicht leisten. Wir wüssten nicht, wie wir die Räume bezahlen."

In the case studies it became obvious that the way of handling the START Programme and the START grantees has changed over time in the Austrian research institutions. The "older" START grantees seem to have been left alone in the preparation of the START project, but also during the project implementation phase. In recent years, institutional support is provided to a greater extent by the host institutions. 


\section{Excursus: The "START-policy of the institutions"}

Although the approach of the institutions towards the START grantees varies, certain pattern can be observed. In the following, the current situation concerning the institutional support is described:

\section{Approach towards potential grantees}

Institutions seem to proactively approach researchers whom they attest to be qualified for such a competitive programme. This is done via the rectorate, the deanery or the service in charge of research promotion (Forschungsservice). Furthermore, excellent researchers from abroad who show interest in a position in Austria are pointed to the programme ("Das ist ein Rekrutierungsinstrument für Incomings"). One interviewee notes in this context that the institution tries to look for projects which especially fit into the research focus and the strategic development of the institution.

In contrast, the interviewed START grantees report that they have taken the decision to apply to the programme mainly on their own or that they have been pointed to the programme by colleagues.

\section{Support in the application phase}

According to the interviewed research institutions, they offer manifold support and consulting in the application phase. This support is optional for applicants. Examples of support activities are:

- The research services ("Forschungsservice") of the universities give feedback with regard to the financial outlines and work plan, the structure of the proposal, language issues (e.g. review by native speakers) etc.

- Some institutions offer workshops in which START grantee share their experience with potential applicants or researchers who are identified to act as mentors. Also the hearings are "staged".

- One institution stated that at the faculties/institutes the resources needed and the framework conditions are discussed beforehand.

The interviewed START grantees did not seem to have made use of the offered support during the application phase to a great extent. Rather, colleagues seem to have supported and counselled the applicants. This could be an indication that the institutions have only developed this support in recent years.

\section{Support of the START grantee in the implementation phase}

After being granted the funding, the framework conditions with regards to the implementation of the project are discussed ("Wir führen eine Art Berufungsgespräch."), e.g. location of the group, availability of rooms/labs, discussion on additional resources ("Das ist nicht leicht aus finanzieller und sozialer Sicht - andere Personen müssen eventuell umgesiedelt werden"). The position of the applicant is clarified as well as the job application for team members. START grantees from abroad are informed about future perspectives ("Wir informieren sie über den Stellenplan, wer wird in Pension gehen etc."). One institution reports that also other working groups support the START groups in this starting phase. 


\section{Excursus: The "START-policy of the institutions"}

The START grantees mainly report of the good support with a view to infrastructure ("Ich wollte einen Raumverbund, das Forschungsservice hat mich tatkräftig unterstützt").

Perspectives for START grantees

Most of the universities offer the START grantee a tenure track position and negotiate a qualification agreement ("Qualifikationsvereinbarung"). If the habilitation is completed within the period of the START project, he/she becomes associated professor (permanent position). Others state that there is no guarantee, but the chances to get a permanent position are enhanced significantly and that programmes such as START are considered in new developed career models ("Wir versprechen eine Ausschreibung in diesem Bereich", "Kein Automatismus, aber die Verhandlungsbasis wird deutlich verbessert").

\subsubsection{Promotion of Young Researchers}

As a direct consequence of the creation of START research groups, young researchers get the possibility to participate in cutting-edge research. The monitoring data of the end-of-project reports hint at the number of young researchers that had been supervised by START grantees at different levels of their education. The following table shows the number of theses supervised by 53 START grantees that have finalised their project by April 2015.

Table 5: $\quad$ Total number and average of supervised theses in START research groups

\begin{tabular}{|c|c|c|c|c|}
\hline & $\begin{array}{l}\text { Total no. } \\
\text { (completed and } \\
\text { ongoing*) }\end{array}$ & $\begin{array}{l}\text { Average } \\
\text { (per START } \\
\text { grantee) }\end{array}$ & $\begin{array}{l}\text { Completed } \\
\text { theses }\end{array}$ & $\begin{array}{l}\text { Average } \\
\text { (of completed theses) }\end{array}$ \\
\hline $\begin{array}{l}\text { Diploma/ mas- } \\
\text { ter's/ bache- } \\
\text { lor's theses }\end{array}$ & 272 & 5,33 & 240 & 4,52 \\
\hline $\begin{array}{l}\text { PhD/Doctorate } \\
\text { theses }\end{array}$ & 298 & 5,62 & 222 & 4,19 \\
\hline $\begin{array}{l}\text { Habilitation } \\
\text { theses }\end{array}$ & 75 & 1,47 & 32 & 0,60 \\
\hline \multicolumn{5}{|c|}{$\begin{array}{l}\text { Total number of START grantees included in the computation: } 53 \\
\text { '* ongoing = not finalised by the end of the START project }\end{array}$} \\
\hline \multicolumn{5}{|c|}{$\begin{array}{l}\text { NB: The figures are taken from the end-of-project-reports of the START grantees and have } \\
\text { been provided by each grantee on her/his own calculation or estimation. The figures have thus } \\
\text { to be interpreted with a certain caution, also taking into account that the START grantee looks } \\
\text { back on a long time period of up to } 7 \text { years. }\end{array}$} \\
\hline
\end{tabular}


A further aspect is the number of START grantees who have not supervised any thesis. Here, the monitoring data show a very positive picture: All START grantees except one (out of 51) have supervised at least one doctoral thesis. Furthermore, 42 out of 51 START grantees have supervised a first degree thesis at least once, such as a bachelor's, master's or diploma thesis. 30 out of 51 START grantees have supervised one or more habilitation thesis.

Beside the fact that the START Programme provides young researchers with the opportunity of participating in top research and of having a job position for this research, at least for a certain period of time, being part of a START research group also seems to strengthen the personal career prospects of the group members. Over $70 \%$ of the START grantees think that this is the case.

Figure 28: $\quad$ Career prospects of the START group members (START grantees)

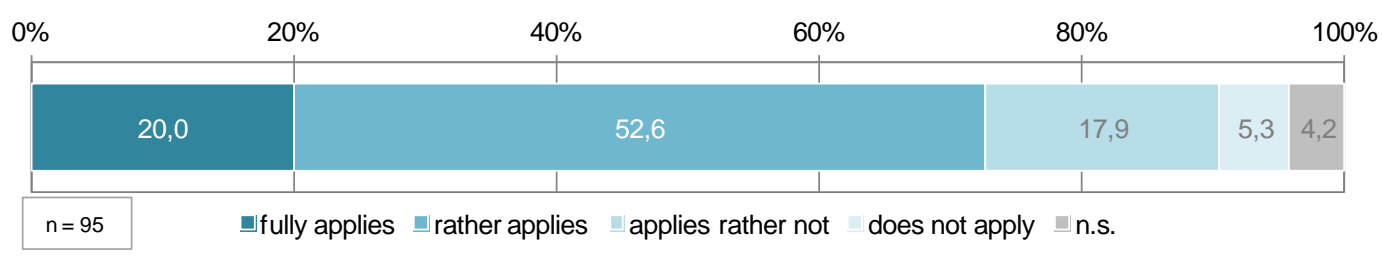

Question asked: "To what extent does the following statement apply: The START grant strenghen the personal career prospects of the employees of the funded projects."

The case studies show evidence of the attractiveness of START projects for young researchers ("Ich bekomme immer noch Bewerbungen"). The teams have been composed either of people who the START grantee already knew or who have responded to international job announcements. The motivations of young researchers to join the START team are: the interest in the topic and in working with the project leader, and to work in an inspiring environment.

The following advantages for team members could be identified:

- Long-term jobs: START offers security, as team members have the perspective of being employed for up to six years. In this context the flexibility of the programme is important. Several interviewees reported that they finished their $\mathrm{PhD}$ before the end of START and had then been further employed as a post-doc student ("lch wurde umgehend hochgestuft als post-doc").

- Research topics: The START projects allows for ground breaking research with a view to content and methods. Thus, these projects open up new fields of research and can offer a good basis for the doctoral thesis and publications. The participation in a START project can contribute to sharpening the researchers' profiles ("START ist ein Impuls.", "Sie sollen und können thematischen Schwerpunkt bilden.") 
- International projects: Being involved in a START project means to work in an international research team. This is perceived as added value by the team members ("People coming from different backgrounds and doing different things", "Durch den reichen Austausch konnte ich meinen Horizont erweitern. "). Furthermore, the international dimension of the projects allows getting to know the management of international projects. ("Ich habe viel gelernt hinsichtlich der Planung und Organisation von internationalen Projekten.")

- Access to the research community: All interviewed team members report the possibility of attaining international conferences/workshops or inviting visiting researchers, as the START Programme includes a travel budget. ("Ich kannte alle relevanten Forscher in diesem Fachbereich am Ende.", "That's beautiful: very good opportunity to go outside, to conferences - a conference visit was the turn up to my first paper due to a discussion with an expert there" "I used the money to invite people for a short time to discuss results").

- Impact on research career: The START project often builds the basis of the team members' research career ("Erhebliche Teile meines CVs beruhen auf Vorträgen und Publikationen aus dem Projekt.") and contributes significantly to the further career development ("START contributed a lot to gain this position in [...]", "START hat mir die Türen geöffnet, um aus verschiedenen hochkarätigen Labors auszuwählen."). The career paths of the interviewed people confirm these positive effects. All young researchers except one stayed in research or plan to do so and advanced in their career or report good prospects (e.g. "Nachwuchsgruppenleiter" at a German university, post-doc positions at universities).

All team members interviewed underline the positive impact of START and state that START offers exceptional framework conditions for young researchers. Therefore, it is not astonishing that all interviewed people would recommend to colleagues to join such a START team ("auf jeden Fall eine Empfehlung", "I would recommend it for sure, it was a very positive experience in [...]"). 


\section{$4 \quad$ Evaluation of the Wittgenstein Award}

The Wittgenstein Award was created in 1996 together with the former Ministry of Research, Transport and Art (BMWVK). Until 2009, the Austrian Science Fund (FWF) administered the programme on behalf of the ministry; since 2010, the programme is part of the aoutnomous funding portfolio of the FWF. . The Wittgenstein Award is remunerated with up to 1.5 million Euros for five years for outstanding researchers. Thus, it is the highest paying award for researchers in Austria. With this award, "prize winners should be guaranteed the maximum possible level of freedom and flexibility in the performance of their research, thereby facilitating an increase in their scientific productivity. "32

Between 1996 and 2014, a total of 30 researchers were awarded, normally one or two individuals per year (in 1998 there were three Wittgenstein Award winners). Between 1996 and 2015, 42.4 million Euros were allocated to the Wittgenstein Award. The target group of the award are outstanding researchers of any discipline of max. 55 years who have had their permanent residence in Austria for at least one year and hold a permanent position (at least 50\%) at an Austrian research institution. Researchers cannot apply for the award themselves but are nominated. Between 1996 and 2014, overall 278 nominations were sent to the FWF.

In the course of time several modalities have changed. The most important changes have been:

- Re-definition of the group of people who are entitled to be nominated (in 1997 and 2008).

- The shift from the age limit of 50 years to 55 years (2007) for receiving the award.

After almost 20 years of its existence, the appropriateness of the programme design with regards to today's need and the impacts that the award has produced in this time span, is to be assessed. This is the objective of the following analysis. It is divided into three main parts:

In chapter 4.1 the programme design is discussed. It looks in particular at the objectives of the award and its main characteristics and discusses whether such an award is (still) timely and how it fits into the FWF portfolio.

32 FWF homepage; http://www.fwf.ac.at/en/research-funding/fwf-programmes/wittgensteinaward/; visited on 05/08/2015. 
Chapter 4.2 analyses the programme management during implementation, and includes an assessment of the nomination and selection process.

Chapter 4.3 investigates the effects and impacts of the Wittgenstein Award in relation to its objectives, especially the possibility of exploring new avenues of research, to promote young researchers and to enhance the visibility of the award winners and of research in Austria.

\subsection{Programme Design}

\section{The objectives of the Wittgenstein Award}

The guidelines for nomination33 show four main objectives underlying the Wittgenstein Award:

- Recognition and support of outstanding researchers who have already produced exceptional scientific work and who occupy a prominent place in the international research community.

- The researchers should be guaranteed a maximum possible level of freedom and flexibility in the performance of their research.

- Facilitation of a remarkable increase in their research productivity by enhancing and extending the research possibilities of the award winners and their groups.

- Promotion of qualified young researchers by employing them in the supported projects.

In the following, these objectives are discussed in more detail, especially the view of the different stakeholders with regard to the aims and objectives that are linked to the programme.

\section{Recognition and support of outstanding researchers}

The award is first of all a recognition for researchers who have produced exceptional scientific work and occupy a prominent place in the international research community. Thus, the former performance and track record are essential. Therefore, it is not astonishing that the Wittgenstein awardees first of all felt honoured ("Es war natürlich eine große Ehre") and are very proud of the recognition they have gained ("eine Anerkennung meiner wissenschaftlichen Leistung", "eine außerordentliche Anerkennung, die einem zeigt, dass man auf dem richtigen Weg war").

33 FWF: Wittgenstein-Preis. Richtlinien für die Nominierung 
The award puts the researchers in the spotlight ("Exzellente Wissenschaftler werden vor den Vorhang geholt", "Ein unheimlicher Wendepunkt in meiner Sichtbarkeit. [...] Weil man früher eigentlich übersehen wurde und auf einmal will jeder wissen, was man denkt") and contributes to the winner's reputation ("Es ist das Renommee", "er verleiht einiges an Prestige") at the national ("Ich war eben bis vor Kurzem universitär noch gar nicht eingebunden") and international level.

The programme is the only one in the FWF portfolio which follows the principle "fund people not projects" to allow outstanding research by individuals who have proved to be excellent and of whom outstanding performances can be expected (see below). Thus, the award is linked to the requirement to spend the money on scientific work ("Auszeichnung, die mit einer Verpflichtung einhergeht").

\section{Freedom and flexibility in the performance of the awardees' research}

The design of the programme has strong blue sky research elements as no project application is requested ("Sie versprechen nix.", "No strings attached"). There are no working plans, milestones etc., the awardees have to describe only very briefly what they intend to do with the funding. Thus, high risk research is supported in which new fields can be explored and disciplinary borders can be crossed.

This freedom in research is very much appreciated by the award winners and seen as a main advantage of the programme ("Es ist einfach wahnsinnig praktisch, dass man da Geld bekommt, um ein paar Leute längerfristig Dinge ausprobieren zu lassen", "Das ist der besondere Luxus des Wittgenstein-Preises, dass man nicht schon vorher in einem Projektantrag sagen muss, was man machen wird, sondern dass man das wirklich entwickeln kann."). Additionally, it allows realising projects which would not have been funded in the framework of "standard" application processes ("Ich habe ein Projekt beginnen können, dass ich nie durch Peer Review hätte durchbringen können. ").

\section{Increase in the research productivity}

The amount of money and the freedom in research is to lead to an increase in the research productivity of the researcher and his/her group. Thus, the age limit for the nominees is to guarantee that the awardees remain in research within an Austrian research institution and have enough time to develop his/her research projects.

The award also releases the awardee from the requirement for further proposal writing, and should allow them to concentrate fully on their research. As a consequence the research productivity is expected to rise. ("Man muss weniger proposals schreiben auf diese Art und Weise wird Zeit freigespielt. Man hat einfach mehr Zeit darüber nachzudenken."). This was also the original intention of the programme that outstanding 
researchers who would probably be successful with most of their applications are relieved from the burden of these processes ("Denen muss man das nicht antun, dass sie fünf Einzelprojekte einreichen müssen").

The freedom of the programme should also allow for unconventional approaches, the development of new methods, interdisciplinary research etc. which can have the effect of boosting the award winners' research.

\section{Promotion of qualified young researchers}

Giving outstanding researchers the possibility of employing and promoting young researchers is one of the programme's objectives of which the public is not aware and which is often forgotten by critical voices. Most of the award is indeed spent on young researchers who get the possibility of working with outstanding researchers ("Die verwenden das Geld auch nicht für sich selber, sondern den ganzen Nachwuchs, den sie in ihren Gruppen unterstützen. ").

\section{Wittgenstein within the FWF-Portfolio}

Within the FWF-Portfolio the Wittgenstein Award represents the most competitive and high end programme. It is an exceptional programme as it funds "people, not projects" and supports blue sky research. Therefore, within the FWF, the programme is highly appreciated ("Wichtig, so einen Spitzenpreis zu vergeben, der diese Komponenten beinhaltet.").

As the Wittgenstein Award in general, and the yearly award ceremony in particular, attracts high media attention (e.g. press conference, reports in all broadsheets), the programme contributes to reaching the objective of the FWF "to emphasize and enhance the interactive effects of science and research with all other areas of culture, the economy and society, and in particular to increase the acceptance of science and research through concerted public relations activities." 34 The Wittgenstein Award communicates the importance of research. Thus, the added value of the programme is in its symbolic and political function ("Symbolwirkung für das System, Bedeutung der Forschung wird hervorgehoben", "Es ist ein wesentlicher Beitrag zum Standing der Wissenschaftler und der Wissenschaft.", "Es wäre wissenschafts- und forschungspolitisch Wahnsinn, das abzuschaffen").

34 FWF homepage; http://www.fwf.ac.at/en/about-the-fwf/corporate-policy/, visited on 05/08/2015. 


\subsection{Programme Management}

\section{The nomination process}

Candidates for the Wittgenstein award can be nominated by the following persons:

- Rectors and vice-rectors for research of the Austrian universities

- The president of the Austrian Academy of Science

- The president of the Institute of Science and Technology Austria

- All former Wittgenstein Award winners

This nomination process is a particularity of the Wittgenstein Award and for most of the interviewees such nominations are appropriate for the specific features of the programme ("Dass es über Nominierungen geht, ist dem Preis auch angemessen.", "Im Prinzip scheint mir das sinnvoll zu sein.", "Ein Preis ist etwas, der einem zugesprochen wird. [...] Es sollte eben bei einem Preis anders sein, als bei einem normalen grant proposal."). In this context, a lack of alternatives to a nomination process is mentioned, too ("Also, ich wüsste nicht, wie man es anders machen kann." "Die Alternative wäre ein massenhaftes Selbstvorschlagsrecht, wie es im ERC läuft. Was natürlich das Auswahlverfahren sehr schwierig und zu viele Erwartungen wecken würde."). Only one awardee assesses the nomination process as not timely anymore and recommends a change to an application process such as the ERC Advanced Grant (in combination with the request for double application as it is the case for the START Programme).

The group of people who are entitled to nominate is seen as an adequate group by the FWF as well as by the Wittgenstein Award winners. Against the background of increasing nominations, reducing the number of individuals entitled to nominate is considered. The jury for example suggests that only one person per institution should have the right to recommend candidates. The awardees make use of their nomination right to a great extent (all interviewed awardees, except one, reported of at least one nomination, most of them have nominated several persons) and emphasise the importance of doing so ("Je mehr Wissenschaftler nominieren können, desto wissenschaftlicher wird es und desto sicherer ist es, dass man niemanden übersieht.").

\section{The selection process}

The final decision for the awarding the Wittgenstein Award is taken by an international jury. This jury is the same as for the START Programme and consists of 14 members of different disciplines. All jury members are renowned and established researchers in their field. 
For each nominee there are two "Jury Members in Charge". The process itself is twostaged.

- Step 1: The respective jury members prepare a shortlist of the nominations they are responsible for. Only short listed candidates are peer reviewed. Since 2014, four to five peer reviews have been required, before 2014 the number of peer reviews was six.

- Step 2: In the jury meeting the nominations are compared and discussed based on the peer reviews and the award winner(s) is (are) selected.

The first step was introduced quite recently in 2013 as the number of nominations exceeded 20 in the last few years. As the reviewer should be at the same academic level as the Wittgenstein candidate and at the same time strict conflict-of-interest rules apply, the FWF speaks of a challenge to identify appropriate reviewers. Thus, measures to decrease the number of reviews by preselecting candidates seemed to be very important ("The burden on referees is terrible"). The reviews assess the research quality of the candidate (e.g. importance of the area of research, level of innovation of the former research, integration in the research community, potential for future development), the quality of his/her research group and its potential for future development, and the implications for other research disciplines or further application going beyond basic research.

In the jury meeting the quality of the nominees is intensively discussed. The jury members state that the decision finding for the Wittgenstein Award is different than in other panels: "We are judging what they have done in the past; you don't know what they will do with the money." First the weaker candidates are cut, so that normally an intensive discussion only includes three to five people. Important aspects that the jury considers are the impact of the candidates on their field, the benefit for the field, the originality of the research. It also is taken into account whether the candidate comes from a rather small university or whether he/she could have another chance to be nominated once again. After such a meeting the jury members report that they often have a kind of "bad feeling" and the question arises: "Did you do justice to everyone?".

On the Saturday after the jury meeting the Wittgenstein awardee(s) is (are) contacted and has (have) to prepare a short abstract on how he/she will spend the money.

\section{Programme implementation process}

In the course of the project, short yearly reports and a final report at the end of the funding period have to be submitted. It includes mainly a report on research/scholarly work conducted within the scope of the Wittgenstein Award, the impact of the Wittgenstein Award on the recipient's research work and broader implications of the Wittgen- 
stein Award. The awardees assess the report as appropriate ("Für 1,5 Millionen darf man auch ein paar Seiten Bericht schreiben.", Ich habe es so genossen, diesen Abschlussbericht zu schreiben [...] da macht man dann auch einen Rückblick und das fand ich eigentlich sehr lehrreich"). The report serves as a basis for the written final evaluation on the research funded by the award through an external peer review.

The project management and the formal requirements seem to be non-bureaucratic and mirror the flexible design of the programme ("Das passt zur Freiheit des Preises.", "Relativ viel Spielraum, wie man die Mittel verwenden kann, aber doch auch klare Richtlinien, wofür man sie verwenden darf [...]. Das war ein Luxus, den ich vorher und nachher in dem Maße nicht genossen habe." There is also much flexibility on how to spend the money: "Im Prinzip ist es ein Topf aus Geld, aus dem man flexibel zugreifen kann, auch vom Timing her". Also the institutions in which the researcher is settled profits from the funding ("spontane Einladungen von Leuten, die man auf einer Tagung getroffen hat [...] da ist gerade auf der Universität kein Geld da".

In this context the FWF as the managing institution is positively assessed compared to other funding organisations ("Die Abrechnung ist wie bei normalen FWF Projekten. Der FWF ist ja viel einfacher zu handhaben als die FFG oder die EU. Das ist absolut adäquat."; "Das hat hervorragend funktioniert, [...] gerade im direkten Vergleich mit dem ERC nachher, also beides probiert und kein Vergleich").

\subsection{Outputs, Outcomes and Impacts 35}

\section{The Wittgenstein Award: Providing freedom and flexibility for research}

The Wittgenstein Award gives outstanding researchers a maximum level of freedom and flexibility in their research. This has obviously led to unconventional research projects and it seems uncontested that the Wittgenstein funds were used for exploring new avenues of research. These entail high risk projects in which results cannot be forecasted ("I used the award to start a completely new line of research in my group" "You are therefore in a position to try high risk or long term projects"). This kind of research would have not been possible in the framework of other programmes where the requirements are usually more restrictive ("Pursuit of the above research goals have been tainted with such high risks that it would have been impossible without the freedom and flexibility offered by the Wittgenstein Prize", "Third aim was devoted to high-

35 In this chapter, the quotations in English are taken from the final reports, the German ones from the interviews with Wittgenstein Award winners. 
risk ideas that would have no chance to be supported in the current funding system", "Ein unglaubliches Privileg, nämlich auch mit Risiko zu forschen [...] Ich weiß nicht, was herauskommt.").The projects implemented show a variety on how new grounds have been broken and in which ways the freedom in research has been capitalised:

- New and adapted methods: Some of the Wittgenstein groups dedicated their work to develop new methods which turned out to become state-of-the art ("Also ich habe das einfach wirklich verwendet, um unsere Methodenbasis zu erweitern in verschieden Richtungen." "[lt was the aim of the project] to develop a global method to investigate [...], the [...] experiment now is the worldwide leading experiment on [...]." "The Wittgenstein project [...] has allowed me to establish experiments that are still unique in the world."). This had also a very positive impact on the expertise of the Wittgenstein group ("Methods that were difficult for us to establish 5 years ago are now becoming routine in the laboratory. "). In order to gain new insights, also methods usually used in other areas of research have been applied to the core research area of the Wittgenstein awardee ("We have adapted the classical [...] approach to be used in combination with [...] to discover novel features [...]"). The implementation of new methods often was linked to the purchase of new equipment which has been enabled by the Wittgenstein funds.

- Interdisciplinarity: In several Wittgenstein projects the funds enabled the integration of an interdisciplinary approach which is very expensive and often not realisable in other types of programmes ("The Wittgenstein project has systematically explored interdisciplinary cooperation to increase the range of its research and impact." "Und dann eben überhaupt so interdisziplinär forschen. Teams zu haben, wirklich die Zeit zu haben, eine gemeinsame Grundlage herzustellen. [...] Das kostet wahnsinnig viel Zeit, dass man da überhaupt sich einig ist und irgendeine gemeinsame Sprache findet.", "Ich konnte Leute ansetzen auf Themen, die komplementär zu meiner eigenen Forschung sind, Leute, die bestimmte Kompetenzen habe, die ich nicht habe [...] Da wird in einem Antrag auch immer die Kompetenz des Antragsstellers bewertet, das ist aber nicht genau mein Gebiet."). The analysis of the Awardees' publications also hints at the direction of increasing interdisciplinary work. Around half of the Wittgenstein Award winners publish in more disciplines than before they won the award.

- New aspects and research questions: The research areas of the award winners have been extended and new resources have been explored ("IIt] enabled research in new areas and with new material combinations, this has already turned into a main asset of the research institution.", "Der Preis hat mir die Möglichkeit gegeben, auch neue Horizonte aufzumachen. [...] dass ich meine inhaltlichen Fragestellungen erweitern konnte um bestimmte Aspekte und auch um bestimmte Quellengruppen." "Auswirkungen der [...] auf andere Bereiche und die Integration weiterer Dimensionen", "Ein paar neue Forschungsrichtungen aufzumachen in unserem Bereich und zu schauen wie weit wir dort kommen, ohne dass gleich konkrete Resultate da sein müssen.").

- Reaction to developments in the research field: As many research areas are characterised by very fast developments, a quick reaction is often essential to re- 
main state-of-the-art and participate in cutting-edge research ("Quickly react when new opportunities opened [...] the PI could maintain and further establish a leading role in the highly competitive research field." "It puts you in a position in which you can react very fast to any new ideas and technology. ").

By using these different approaches not only high-level research has been conducted, but new avenues of research have been explored, scientific performance increased, and the visibility of research in the national and international research community enhanced.

\section{New avenues of research}

The many successful applications for further funding indicate that new avenues of research have been explored with the support of the Wittgenstein Award. The publication analysis shows that half of the Wittgenstein awardees have published in different research fields before and during the award. This is an indication that new /other fields of research have been explored during the funding period and have resulted in publications in scientific journals. Also in the final reports and in the interviews it is emphasised that the Wittgenstein projects opened up many opportunities for further research ("Besides offering unique possibilities to develop new drug targets and medicines, this research has far-reaching consequences for agriculture, food safety and human health", "Wo dann herausgekommen ist, dass das wirklich eine ergiebige Forschungsrichtung ist, die völlig unbeackert war bisher.", "Und ich würde auch sagen, dass es in unserem Fall sehr gut funktioniert hat, weil es uns dann die Basis gelegt hat für eine ganze Menge neuer Projekte.")

\section{Increased scientific performance}

The bibliometric analysis of the awardees' publications shows a clear increase of the scientific performance. Two-third of the awardees publishes more during the award compared to the period before the award. With regard to the overall "career" of the awardee (here only the period between 1996 and 2014 can be looked at, due to database restrictions) it can be seen that for some Wittgenstein awardee their personal "publication peak" falls into the award period. The list of publications (publications in high-level journals, books and book chapters etc.) in the final reports as well as statements in these reports and in the interviews also witness the high research productivity of the Wittgenstein Award winners and the relevance of the research undertaken ("The years of the Wittgenstein project have been some of the most productive in my professional life so far." "Meine zweitmeist- und drittmeist-zitierte Arbeit ist aus diesem Umfeld entstanden." "Das war für mich wahrscheinlich die beste Zeit in meinem Leben von meiner wissenschaftlichen Arbeit her, weil dadurch kreativ enorm viel gelaufen ist. "). 


\section{International visibility of Austrian research}

With the Wittgenstein funds the awardees and their groups could expand and maintain their leading role in their respective fields ("a unique opportunity to invest in equipment and personnel that would expand are capacity and skills [...], ensuring that we and other researchers at the [...] could remain at the cutting edge of these developments"). This was often supported by a sustainable institutional integration of the respective research areas and manifests itself through e.g. the founding of new institutes or units, additional professorship positions or upgrades of institutes in terms of staff and budget.

Not only are new research groups established, but these groups and the host institution are perceived as leaders in their respective fields. This contributes to increased visibility and the international reputation of the awardees and their research (groups) and leads to strengthening Austria as a location for research. In one case, the Wittgenstein fund was used to create a "Wittgenstein Centre" which merges different institutions in order to create a centre with international visibility and reputation. ("Wir müssen diese drei Institutionen, die alle unter meiner Leitung gestanden sind, zusammenfassen, um auf globaler Ebene ein Major Player zu werden. [...] Unsere Gruppe wird sicher als eine der weltweit führenden Gruppen angesehen, in Europa als die dynamischste." Other examples can also be found: "[lt] expanded the international visibility of the [...] in this important research field", "It can certainly be said the prize enhanced the international visibility of the prize winner, and of Vienna as a centre of [...] studies", "I dare to say that the Wittgenstein money was an enormous help in growing the global awareness of my [...] Group in Vienna. ").

This reputation goes along with many co-operations at national and international level which have been established, expanded and intensified ("Strong international collaborations have been established centred on various topics of relevance."). This results in further activities in international networks and co-operations ("These capacities allowed us to explore new collaborations with led to the establishment of the [...] project. ").

In order to intensify these international co-operations, outstanding researchers have been invited to participate in the research projects for a limited period of time ("40 international or national guests were invited to participate [...] as keynote speaker, guest lecturers, workshop and conference contributors, or co-contributors to publications"). It was emphasised that only the specific flexibility of the award provided this opportunity. The international exchange as well as the international visibility has also been benefitted from the organisation of conferences in Austria ("We have organized a major conference on [...] in Austria", "Conferences were a backbone of the project."). 


\subsubsection{Impact on the Awardees' Research Career}

The Wittgenstein Award, leading to the recognition of outstanding researchers, contributes also significantly to the visibility of the awardee. Mainly the reputation within the research community seems to further increase, as stated in the final reports and the interviews ("It is obvious that the international reputation of the PI strongly benefitted from the Award.", "The Wittgenstein prize had a very positive effect on the international reputation of the prize winner himself. It is the combination of the impressive amount of prize money with the well-chosen name of the prize which makes its importance internationally visible." "Sowohl national als auch international verleiht einem das einfach Prestige."). Especially at the international level the research undertaken with the award, had a positive impact on the visibility of the awardee ("Das hat schon dazu geführt, dass das, was ich mache, schon auch noch ein bisschen international sichtbarer geworden ist.", "Sichtbarkeit nicht nur in Österreich, sondern auch weltweit.", "Man wird ernst genommen, in höchsten UNO-Kreisen und bei Verhandlungen").

The Wittgenstein Award seems not only to increase the visibility and reputation of the award winners but has a very positive impact on their career. The bibliometric analysis of publications shows that some awardees further increase the number of publications in the period after the award. In the interviews it has been stressed that the award represented an important boost in the already very advanced career ("Es hat gerade auch in meinem Fall meiner Karriere noch einen wichtigen Anschub gegeben, vor allem auf internationalem Niveau." "Ich habe absolut sicher einen Quantensprung gemacht. [...] also die Bekanntheit erhöht sich und dann ist das ein Schneeballeffekt."). This is reaffirmed in the final reports ("The awardee feels that the Wittgenstein Award had an important and long-lasting impact for the further course of his career.", "In short, my career and reputation have gone steeply upwards ever since I received the Wittgenstein Prize - and that was clearly and decisively promoted by the prize."). But also the acquisition of ERC Advanced Grants, the Membership in the Austrian Academy of Science and the winning of other international and national research awards by several of the Wittgenstein Award winners evidence this impact on the further career.

\subsubsection{Promotion of Young Researchers}

The Wittgenstein Award should enable the awarded researchers to promote young researchers by employing them in their group and thus giving them the possibility to work with outstanding researchers. It turns out that in most of the cases an important part of the funds have been spent on young researchers ("A significant part of this Wittgenstein budget was spent on the promotion of junior scholars"). Moreover, the Wittgenstein awardees point out that the promotion of young researchers is one of the key aspects of the programme: 
"This is maybe the aspect of the Wittgenstein program granted to me where the success is most visible and spectacular. After all, by far the greatest part of the funds [...] went into salaries for young scientists.", "More important than facilitation a new level of productivity for my own research, however, was that the prize allowed me to combine this with, and to initiate, a large-scale, empirical, and comparative project with junior researchers", "Es ist ja in gewisser Weise eine umgeleitete Nachwuchsförderung.", "Die Leute übersehen da einen wesentlichen Punkt. Damit werden tatsächlich auch junge Leute finanziert und angestellt und haben die Möglichkeit bei ganz renommierten Leuten wissenschaftlich tätig zu sein." "Es ist zwar ein Mensch, der den Preis bekommt, aber es ist nie ein Mensch, der forscht. Man kann nur in Teams forschen.", "Da geht es darum, dass man junge Leute finanzieren kann."

The groups have been composed of researchers recruited via international job announcements and staff that had already worked with the principal investigator or in his/her environment. In this context, the possibility to attract the best young researchers from all over the world has been emphasised ("It allowed me to offer exceptional candidates post-doc positions.", "Da kamen wirklich sehr gute Bewerbungen aus aller Welt, die man nicht bekommt, wenn man nur ad hoc eine Stelle zu besetzen hat", "Ich bin in der Lage gewesen, die internationalen Top-Postdocs [...] zu bekommen. Es hat dann einfach keine finanziellen Probleme gegeben. Man hatte die opportunity, jemanden zu bekommen, wo man sonst nachdenken musste, war das Geld eben vorhanden."). Furthermore, the flexibility of the programme enables to employ promising candidates very spontaneously ("Man kann ein paar junge Doktoranten anstellen, die gerade da sind und die eigentlich super sind, für die ich aber kein Projekt gehabt hätte.", "Man lernt die Leute kennen, die trifft man irgendwo auf Konferenzen. [Dann hat man die Möglichkeit zu sagen:] Du fängst in einem Monat an oder in 1 1/2 Jahren").

The monitoring data of the final reports give a hint on the number of young researchers that had been supervised by Wittgenstein Award winners at different levels of their university education. The following table shows the number of theses supervised by 14 Wittgenstein awardees that have finalised their projects and delivered their final report by April 201536. 110 diploma/master's/bachelor's theses and 109 doctoral theses have been supervised. 23 researchers have written their habilitation thesis in the framework of Wittgenstein projects. It has to be noted that the number of supervised thesis in a Wittgenstein group varies considerably. There are Wittgenstein awardees/groups that are very active in the supervision of all three types of theses, with sometimes a considerable amount of supervisions (e.g. one Wittgenstein awardee supervised $15 \mathrm{PhD}$ the-

36 Out of 17 final reports, only 14 contained information on the number of supervised theses. 
ses, another 22; or 30 diploma theses). It is assumed that this is the overall number of theses produced within the Wittgenstein research group; i.e. not necessarily under the direct supervision of the Wittgenstein awardee him/herself. But, the monitoring data also show that some awardees have almost supervised no thesis.

Table 6: $\quad$ Total number of supervised theses in Wittgenstein research groups

\begin{tabular}{|l|c|}
\cline { 2 - 2 } \multicolumn{1}{l|}{} & \multicolumn{1}{c|}{ Total no. (completed and ongoing*) } \\
\hline Diploma/master's/bachelor's theses & 110 \\
\hline PhD/Doctorate theses & 23 \\
\hline Habilitation theses & 109 \\
\hline $\begin{array}{l}\text { Total number of Wittgenstein awardees included in the computation: } 17 . \\
\text { * ongoing = not finalised by the end of the Wittgenstein funding period }\end{array}$ \\
\hline $\begin{array}{l}\text { The figures are taken from the end-of-project-reports of the Wittgenstein awardees and have been pro- } \\
\text { vided by each grantee on her/his own calculation or estimation. The figures have thus to be interpreted } \\
\text { with a certain caution, also taking into account that the Wittgenstein awardee looks back on a long time } \\
\text { period of up to } 6 \text { years. }\end{array}$ \\
\hline
\end{tabular}

The young researchers can profit from working in a very favourable and stimulating environment ("Verschiedenen Ländern, verschiedenen Disziplinen, verschiedener Ausrichtung und verschiedener Expertise. Davon, glaube ich, profitieren sie am meisten."). The access to the international community has been facilitated by different approaches:

- In the framework of several Wittgenstein projects international seminars and workshops have been organised and international experts could be invited for an experience exchange ("II] run a regular seminar programme, and invited thereby 20 prominent scientists each year to come to our group and discuss science. ", "I organized a Wittgenstein workshop every year [...] which had the formula of a group retreat to which we invited scientists that work very close to our topic.", "Wir hatten einfach die Möglichkeit, Seminare mit ganz tollen Experten zu organisieren").

- The participation in international conferences is financed through Wittgenstein ("They also were able to present papers at international conferences and to share in the organization of panels.", "Der Wittgenstein Preis hat mir auch die Möglichkeit gegeben, die alle auf internationale Tagungen zu schicken. [...] Das muss man sich einmal leisten können, Doktoranden und Postdocs dorthin schicken zu können.").

- The Wittgenstein Award winners also supported publication activities of their young researchers to a great extent ("In addition, the prize allowed hitherto unheard of investments in preparations for the publication of junior research results. ", "All team members had many opportunities of co-authorship of books [...], articles in peerreviewed journals or chapters in books." "[...] additional expenses were raised for promoting their careers [...] through investing in professional copy-editing of some of their English publications.") 
Thus, by being part of a Wittgenstein group young researchers are able to take an important step towards a research career ("The Wittgenstein money thus gave the opportunity to enhance their CVs and build their own international networks.", "Support by the Wittgenstein funds was critical for the training and career development of several young scientists"). This is evidenced when looking at some Wittgenstein team members who had a remarkable career. Several START and ERC Starting grant awardees were previously part of Wittgenstein groups; other researchers were successful in the application of programmes such as Marie Currie or Lise Meitner. Furthermore, the research careers of the team members seem to be sustainable ("Several of the scientific staff were appointed as professors at leading international scientific institutions.", "Many of the PhD students were successful in finding top-jobs as post-docs afterwards.", "Also diese Leute haben zum Teil fantastische akademische Karrieren gemacht und sind jetzt in internationalen Spitzenpositionen", "Zu meiner eigenen Verblüffung waren es eben 17 Leute, die eine erfolgreiche akademische Karriere starten konnten.").

\subsubsection{The Wittgenstein Award and Public Awareness}

The Wittgenstein Award ceremony has a remarkable publicity in the media. Broadsheets write about the award and interviews with the awardee are published in several newspapers and journals. This - at least temporary - media attention provides the possibility to communicate on research to a wider public ("Verleihung hat gewissen News-Wert"). The fact that an individual is in the focus facilitates the communication to a wider public ("Über Personen lässt sich das Thema viel leichter transportieren.").

The Wittgenstein Award winners themselves are also active in communicating research to a wider public by different means, as stated in the final reports:

- They write articles in broadsheets and are available for interviews.

- They contribute to reports for television.

- They appear in forums and talk shows.

- They give lectures to the public.

- They participate in the "Kinderuni" (an event in several universities for children to gain first impressions of research and different studies).

- They participate in events for the wider public, e.g. "Lange Nacht der Forschung" (long night of research).

- They maintain a website.

Additionally, the Wittgenstein Academy has been funded with the aim to present cutting-edge research in schools, even if the interest in schools has been up to now rather 
low. This might generally effect the acceptance of science communication activities from the point of view of (excellent) researchers and raises the question to which extent researchers are responsible for communicating research and whether he/she has to rely more strongly on support by the PR-services of the host institutions or funding agencies or the media themselves ( "Wieviel Aufwand in der Erklärung und Problematisierung von Forschungsergebnissen kann man sich als Forschender leisten? Da ist teilweise die Unterstützung, die man bekommt von den Institutionen, von den Medien, noch verbesserbar.").

It is undisputable among the awardees that the Award has a high potential to communicate research, as the communication can be centred on one individual ("Ich glaube ja, es ist die Medienwirkung. Also der Preis hat es geschafft innerhalb weniger Jahre zumindest bei den Journalisten und bei Teilen der Öffentlichkeit wirklich als das besondere Label zu werden. Ein Wittgenstein Preisträger: das ist etwas Tolles. "). Also the interviewees emphasise that they feel committed to a certain extent to such PR activities ("Wenn man da ein bisschen was tun kann, um die Sichtbarkeit der Spitzenwissenschaftler zu fördern, dann ist das sicher gut", "Ich glaube, dass da schon die Wittgenstein-Preisträger immer wieder aufgefordert sind, sich auch in der Öffentlichkeit zu Wort zu melden."). Nevertheless, they state that much more could be done to explain research to the public and raise the acceptance of basic research. Here, the Wittgenstein Club, an initiative of one Wittgenstein awardee regrouping all current and former awardees, could be mobilised ("Das sollten wir eigentlich mehr nutzen. Wir [Wittgenstein/ERC/START-Preisträger] wären doch eine unheimlich starke Gruppe."). An increased activity of the Club in this respect is also favoured by the FWF. 


\section{$5 \quad$ Conclusions}

\subsection{The START Programme}

\section{Are the programme and its goals timely?}

\section{START within the FWF funding portfolio}

The START Programme targets researchers at a late stage of their post-doc phase, at the edge of institutionalisation into the research system. This is a decisive career phase in which excellent researchers may leave the Austrian research system due to a lack of long term perspectives. The START Programme is the only programme in Austria which provides a kind of "starter kit" for a research career. The gathered evidence indicates that numerous START grantees would have left Austria without the START Programme in order to take a research position abroad. The outcomes of the START projects with regards to scientific performance allow the conclusion that the provision of a substantial amount of funding stretched over a long period of time is an element needed to yield significant results in basic research and push the frontiers of knowledge. The high prestige of the grant is furthermore conducive to the career development in the Austrian research system. By combining the funding of excellence research with career development elements, the START Programme is unique in Austria and has an important role in the FWF funding portfolio.

\section{START in comparison to ERC}

The only comparable funding instrument available to researchers in Austria is the ERC Starting grant. Even though internationally not as known as the ERC Starting grant, the START Programme is seen as a valuable and equivalent alternative to ERC by the research community in Austria. The obligation for the double application to both has caused the ERC to become well known in Austria. Today, Austrian researchers are very well represented within the group of ERC applicants and very successful in winning ERC grants, in comparison to other European countries. Today, the main argument for the coexistence of these two programmes is the exceptional resources both programmes provide to young researchers in a decisive career phase, hence the possibility to provide more researchers with such an exceptional kind of funding. As these kinds of grants are few and very competitive, the double application, requested by the FWF since the introduction of the ERC Starting grant, is accepted by the majority of researchers. 


\section{Are the design and the management of the programme appropriate?}

\section{Design of the programme}

The START Programme addresses all relevant elements needed to promote research excellence and the career development of young researchers, and this for both the START grantee as well as the group members of the START project. The level and duration of funding can be seen as adequate to reach these goals. Hence, one can conclude that the START Programme is designed in a way which contributes to strengthening the Austrian research system in a longer time perspective. The goals of the START Programme are shared by the different stakeholders and expectations of the START grantees towards the START Programme have been met to a high degree.

\section{Selection process and selection bias}

The selection process of the START grantees is appropriate to the nature of the programme. Especially the use of an international jury as the main decision maker is incontestable. The decision finding processes are assessed as fair and transparent, even if the composition of the jury with regards to disciplines is a recurrent point of discussion for all stakeholders. However, the composition can be assessed as balanced, taking into account the need for a restricted number of people in such a committee on the one hand, and the high number of research disciplines to be covered, on the other.

The programme's sole selection criterion is 'research excellence'. The evaluation reaffirmed that this is the guiding principle of the jury's decision. The bibliometric analysis showed that the START Programme selects the most qualified researchers. The START grantee group differs - sometimes considerably - compared to the whole population of researchers in Austria with regards to its disciplinary composition and to some extent regional origin. This bias is already introduced at the application stage, i.e. researchers from the fields of mathematics and physics tend to apply more often for a START grant, while researchers from the fields of biotechnology/medicine and natural sciences others than physics apply less in proportion to the overall number of researchers in these fields and region. This tendency is reinforced by the selection of the START grantees. This distribution pattern shows that there are certain "hotspots" (geographical and disciplinary) which receive above average START funding. This hints at the conclusion that START has contributed to shape regional and disciplinary "hotspots" of research excellence. 


\section{Programme management}

The START Programme is a very well managed programme with reasonable administrative requirements. In comparison with similar programmes, especially the ERC, the administrative burden is low. Especially the personal relations with the FWF programme management are highly valued.

\section{What are the impacts of the START Programme?}

\section{Research impacts}

The analysis suggests that the START Programme has considerable positive effects on the scientific performance of the researchers receiving START funding, during the funding but also for their future scientific performance. START grantees perform better than the control group for all indicators measured. There is evidence that the START Programme allows for testing new and unconventional research fields. Furthermore, the research project would not have been realised or only to a considerably lower extent, without the START funding.

\section{Outputs beyond scientific publications}

START projects were especially conducive for areas that are close to research, such as project acquisition and establishment of cooperation. Research results have furthermore be used for teaching purposes or for commercial purposes. Research results have also been communicated into society via e.g. mass media or public relation activities. With its high reputation, the START grantees and the START Programme are very visible in the research community in Austria. The START Programme thus contributes to the visibility of Austrian research, the convergence of the Austrian research system towards international cutting-edge research and the attractiveness of Austria as a location to conduct research.

\section{Career development of the START grantees}

The START Programme positively contributes to the career development of the START grantees. All START grantees stay in the research system. The majority of them remain in an Austrian institution, still, a third of START grantees are employed in a foreign research organisation after the end of the START project. Almost $80 \%$ of START grantees hold a professorship. However, the control group follows similar career paths as the START grantees. They also hold similarly often professorship positions and are appointed as professors in the same time span as the START grantees. 
For START grantees, the reception of the START grant is often seen as the decisive element to remain in Austria. With regard to gaining a permanent position in the research system, a START grant opens up the possibility to negotiate such a permanent position. Today, the majority of research institutions offer the START grantee a tenure track position.

\section{Interaction with the host institution}

The majority of START grantees see their negotiation position vis-à-vis their research organisation as to the shaping of research conditions strengthened due to the START grant.

The esteem of START grantees has changed considerably since the programme started 20 years ago. Today, host institutions see START as an asset for their institution. Hence, Austrian research organisations provide support to the START grantee during the application process and in the implementation phase, they are actively encouraging researchers to apply for START and try to offer job perspectives for the period after the START project.

\section{Promotion of young researchers}

A START project group is an effective instrument for qualifying young researchers. They provide young researchers with access to top level research and to the relevant research community. START grantees have supervised numerous qualification theses, such as master's and PhD theses. The international character of the group is equally well appreciated as is the good availability of funding for mobility and exchange with the research community. Furthermore, with its long term and flexible funding, it provides young doctoral and post-doc researchers with longer term working contracts (up to six years), which is still exceptional in the research system.

\section{Visibility of the START Programme}

Today, the START Programme is highly regarded and well known in the Austrian research community and to some extent also in the international research community. This analysis shows that the START Programme has not had this status since the beginning, but the "brand" START needed time to fully develop. 


\subsection{The Wittgenstein Award}

\section{Are the design and the management of the programme appropriate?}

\section{Design of the programme}

The Wittgenstein Award addresses key elements which are crucial for outstanding researchers. It is on the one hand a reward for outstanding scientific performances of the awardees in the past, and on the other hand an instrument which allows a maximum of freedom and flexibility in research. This in itself can lead to an increase in research productivity. Furthermore, the awardee receives recognition in the form of the highest paying award for researchers in Austria which can put the researcher and scholarship as such into the spotlight. As the Award foresees the promotion of qualified young researchers with the funds, support is not only given to the awardees but also to the team members - promising young researchers. Hence, the design seems appropriate to the target group and can contribute to strengthening the Austrian research system. This view is shared by all stakeholders.

\section{Wittgenstein within the FWF portfolio}

The Wittgenstein Award is the only programme of the FWF which follows the principle "fund people, not projects" and which allows blue sky research. As the most competitive and high end programme, it gains media attention and certain publicity. By combining these elements, it is unique in Austria.

\section{Nomination and selection process}

The nomination process is a particularity of the Wittgenstein Award and seems appropriate to the nature of such an award also with a view to a lack of alternatives. Although the group of people who are entitled to nominate candidates are seen as adequate, a reduction of this group of people is proposed to reduce the number of nominations.

An international jury is in charge of selecting the candidates on the basis of peer reviews. A specific element of the process is the fact that the selection is only based on the candidates' past performance as no proposal is required, indicating how the funding will be used. As outstanding researchers are assessed, the quality of the peer reviewers and the jury members is to be crucial for the acceptance and legitimisation. Thus, they have to be on a similar level of expertise as the candidates. 


\section{Programme management}

The programme management and the formal requirements (short yearly reports, final report) mirror the flexibility and freedom of the programme. Compared to other funding organisations the FWF turns out to be very non-bureaucratic.

\section{What are the impacts of the Wittgenstein Award?}

\section{Impact on research}

The Wittgenstein Awards have undoubtedly facilitated the pursuit of unconventional and creative research streams and high risk projects, an increase in the scientific performance and in enhancing the visibility of Austrian research. The freedom in research has been used to develop new methods or adapt methods to other research fields, to conduct interdisciplinary research or focus on new aspects and new research questions. The exploration of new avenues of research is evidenced by the many successful applications for further funding and the publication analysis. These kinds of projects would not have been funded in the framework of other programmes.

The increased research productivity of the Wittgenstein groups is witnessed by the numerous high level publications and the fact that the majority of the awardees publish more during the award phase than compared to the period before.

With the funds the Wittgenstein groups could expand and maintain their leading role in cutting-edge research. The awardees' research groups are perceived as leaders in the respective fields. This contributes to increased visibility and international reputation of the awardees and their research (groups) and lead to strengthening Austria as a location for research. In this context, many co-operations have been established and intensified.

\section{Impact on the awardees' research career}

The Wittgenstein Award increases the visibility and reputation of the awardee mainly within the research community at national and international level. The Award has also a very positive impact on the already very advanced careers of the awardee. This is evidenced by the acquisition of ERC Advanced Grants, the Membership in the Austrian Academy of Science and winning further international and national research awards.

\section{Promotion of young researchers}

A Wittgenstein group represents a favourable and stimulating environment. An important part has been spent on young researchers who profit from access to top level re- 
search and to the international research community. Wittgenstein Award winners have supervised numerous master's and doctoral thesis.

The sustainable positive impact for the team members is mirrored in remarkable careers. Many are established in the research system, hold high positions as post-docs or at the level of a professor and/or are successful in applying for highly competitive grants (e.g. START, ERC, and Marie Curie). 


\section{$6 \quad$ Future Options and Recommendations}

\subsection{START Programme}

\subsubsection{Future Options of the START Programme}

Based on the findings found during the evaluation, five options for the future of the START programme have been put forward by the evaluation team and discussed in a workshop with the FWF, the ministry, START grantees and Wittgenstein Award winners. The options and their assessment are based on the discussion in the workshop and the evaluation findings are described hereunder:

\section{Option 1: "Weiter so" (“Keep it up”)}

This option involves the continuation of the START programme in its current design.

Assessment of the option: The START programme has produced the effect it aimed at, both, in term of research output and qualifying young researchers for a permanent position in the Austrian research system. Furthermore it contributes to develop the human resource pool (via the funding of research groups) and the visibility of research in the Austrian broader public. There is currently no similar funding scheme in Austria for this target group. The START programme is therefore important for the Austrian research system and highlights the value of excellent research in Austria. It is recommended to maintain the START programme.

\section{Option 2: Introducing a Pre-START programme:}

In this option, the START programme is transformed in a programme targeting researchers at an earlier stage of their career, i.e. directly after the doctoral graduation or in an early post-doc phase. This would give young researchers the possibility to conduct independent research at a very early stage and thus gain qualification for competitive programmes with a high reputation such as the ERC.

Assessment of the option: The funding landscape for post-doc researcher at an early career level is seen as sufficient in Austria. Furthermore, the early post-doc years are seen as phase in which international mobility is and should be sought. A programme retaining young researcher in Austria is not seen as useful in this phase. The real funding gap is seen in the late post-doc stage at the edge to the establishment into the research system and a professorship. Option 2 is not favoured, both by the evidence of the evaluation and the workshop participants. 


\section{Option 3: Funding excellent research groups; no specific focus on the aspect of career development of young researcher}

This option aims at opening the START programme to researchers of any age. The first priority of the programme would be to funding excellent research and research groups. The aspect of promoting young researchers' career has no priority to the programme anymore.

Assessment of the option: As the evaluation shows, the START programme supports the development of excellent research. Beside the research output, it furthermore provides young researchers with important skills needed to gain a professorship position in Austria: independence in conducting research; consolidation of the own research profile; experience with the management of a research group. The evaluation shows that the START grantees value the effects of the START programme on the career even more than the research output. With its possibilities and reputation the START programme is an option for excellent young researcher to stay in the Austrian research system (or even come or return to Austria). For the moment, there is no other funding scheme in Austria targeting this specific group and its needs. Decoupling the career development aspect from the START programme is not seen as beneficial for the sustainable viability of the current Austrian research system.

\section{Option 4: Post-START / Austrian ERC-Consolidator grant}

Similar to option 3 and in opposite to option 2, a post-START programme aims primarily at funding excellent research. In opposition to option 3, the target group of option 4 are mid-age researcher. This START grant would be similar to the ERC Consolidator grant. It can also be seen as a preparation to the Wittgenstein Award.

Assessment of the option: By the workshop participants, this option is seen as funding source which should finance the continuation of the START projects. Rather than funding new research projects, it should be aimed at further developing already existing research projects and consolidating research topics with the aim to guaranteeing better longevity of the research. Another central aim should be the education of young researchers, especially doctoral candidates and young post-docs. A post-START programme should however not replace the actual START programme, but rather come as supplement or extension to the existing START programme. This could be done in form of a two or three year prolongation of the START-project. As the focus of the postSTART funding should not be any more on the career development aspect of the START grantee, a strong commitment of the host institution is to be sought (e.g. through a co-financing agreement or similar). 


\section{Option 5: Abolition of START}

This option suggests the ceasing of the START funding, e.g. in order to distribute the funding towards other existing programmes of the FWF.

Assessment of the option: With regard to the research output the START funding produces and the bridging function it has in the Austrian institutional research landscape, this option is not recommended.

\subsubsection{Core Recommendations for the START Programme}

Based on the aforementioned conclusions, a continuation of the START Programme in its present form is recommended without any reservations. The START Programme has a considerable positive effect on the scientific performance of START grantees: and contributes strongly to the career development of START grantees. Furthermore, a START project group is also an effective instrument to enhance the qualifications of young researchers. Insofar the START strengthens the Austrian position in the global competition for the best researchers.

However, a number of minor changes regarding the programme design might improve the overall performance of and satisfaction with the programme.

- Although the role of the host institution is slowly changing, some past START grantees missed a formal negotiation procedure between the grantee and the host institution and criticised the lack of commitment and assistance by the host institution towards the START grantees. It is suggested that host institution commits itself more strongly and tacking the form of a formal negotiation procedure. A further suggestion was that a stronger involvement in the teaching activities of the host institution could be beneficial for a future career in the university system.

- The selection process is, by nature of this kind of programme, a very contested and discussed part of the START programme. All in all the selection process is assessed as appropriate and well functioning. However, the following recommendations are suggested:

Jury: In order to avoid a complete change of the Jury every ten years, it is suggested to appoint new jury member every three years. This rotation allows a renewal of the jury as well as a transfer of knowledge between new and experienced jury members.

$>$ Hearing: Accordingly to the selection process of the ERC grants, a group of jury members according to disciplinary backgrounds could be envisaged. This "panel" would then be the one participating at the hearing of the corresponding projects, instead of the heterogeneous jury. 
> Communication: the selection process is complex and involves several steps, loops and stakeholders. Furthermore it has been changed from time to time in the last years. It is recommended to increase the communication and explanations on the different procedural steps (e.g. related to the process of collecting peer reviews) towards the applicants.

- Visibility of the programme: With regard to the high reputation of the programme and the focus on single researchers, it is recommended that the FWF uses the PR potential of the grant more strongly. For the moment the START grant is present in the mass media at the grant award ceremony. It can be thought of to inform the public about the START grantee and its research more often. If wished, more PR activities to promote START in the international research community could be envisaged.

- Community building: START could be strengthened as a "brand" through networking among the former and current START grantees.

\subsection{Wittgenstein Award}

\subsubsection{Future Options of the Wittgenstein Award}

Based on the findings found during the evaluation, five options for the future of the Wittgenstein Award have been put forward by the evaluation team and discussed in a workshop with the FWF, the ministry, START grantees and Wittgenstein Award winners. The options and their assessment based on the discussion in the workshop and the evaluation findings are described hereunder:

\section{Option 1: "Weiter so" (“Keep it up")}

This option involves the continuation of the Wittgenstein Award in its current design.

Assessment of the option: The Wittgenstein Award has so far produced very positive results for the research system. Several other countries have similar awards for outstanding researchers. Compared to awards in other countries, the amount of funding of 1.5 million Euros is low. The Wittgenstein Award is thus seen as a good investment in the research system. It is therefore recommended to maintain the Wittgenstein Award.

\section{Option 2: Funding of research groups only, no funding of equipment}

In this option it is suggested to restrict the way of spending the money and restrict the use of the money for funding people i.e. research group members only. Currently it is up to the Wittgenstein awardee to decide upon the best usage of the funding; he/ she can also choose to buy equipment with the money. 
Assessment of the option: By imposing to the Wittgenstein awardee certain conditions the originally intended flexibility would be ceded and his/ her freedom of research restricted. The evaluation furthermore shows that a big part of the funding is already today targeted towards the research group. Moreover, in specific research fields the purchase of (in some cases very expensive) equipment only enables groundbreaking research and creates an optimal research environment the young researchers can profit from. A change in the direction of option 2 is therefore not deemed necessary and could for some disciplines be counterproductive.

\section{Option 3: Selection of awardees from a predetermined research discipline}

Currently, no disciplinary quota exists. Each year one (or two) Wittgenstein awardee(s) is (are) selected who is (are) assessed to be one of Austria's best researchers, regardless of his/her research discipline. Option 3 foresees to choose every year one (or two) main research discipline (life sciences, natural and technological sciences, social science and humanities) from which an awardee is then selected. As there is currently only one award per year (exceptionally two), it is suggested to use a rotation principle for the disciplines. With this option it will also be possible to address the different financial needs existing in different research disciplines.

Assessment of the option: This option would allow a more targeted selection process as the jury could be composed more homogeneously. However, this procedure would also mean not to choose on excellence only, but on a sort of predetermined quota. The distribution of research disciplines among former Wittgenstein Award shows that there is no strong disparities between disciplines. Hence, already today the money is not used to fund a specific discipline in particular. Another strength is that inter- and transdisciplinary research van be rewarded and further developed by the awardee. Using a more disciplinary selection process might exclude researchers whose research activities have been "out of the box" in the past years. With regard to negative reputation effects, this option is not recommended.

\section{Option 4: Funding several high-end research projects instead of one award}

Rather than distributing an award to an individual researcher, this option suggests to fund excellent research projects, selected on the basis of a competitive assessment of the project idea.

Assessment of the option: The strong asset of the Wittgenstein Award is its complete freedom and possibility to think beyond a pure project logic which is currently dominant in the research system. Distributing 1.5 million Euros to projects would allow funding 
five to 6 individual projects only; the scaling effect, often needed in research, would not be guaranteed any more. As the current approach of the Wittgenstein Award has been beneficial to promoting new avenues of research, high risk and cross-disciplinary approaches, it is recommended to continuing the Wittgenstein award in its current form.

\section{Option 5: Abolition of the Wittgenstein Award}

This option suggests the ceasing of the Wittgenstein Award, e.g. in order to distribute the funding towards other existing programmes of the FWF.

Assessment of the option: With regards to the research output the award generates, the strength of the Wittgenstein groups young researchers can profit from and the reputation effects it has for the Austrian research system, this option is not recommended.

\subsubsection{Core Recommendations for the Wittgenstein Award}

The Wittgenstein Award seems tailor-made to its target group and has an added value to the research system in Austria. Hence, it is recommended to continue the programme.

However, a number of minor changes regarding the programme design might improve the overall performance of and satisfaction with the programme.

- The nomination is seen as an adequate way on how to find the candidates for the Wittgenstein Award. However the work load for the international jury is quite high, due to the high amount of nominations. One possibility would be to reduce the number of nominations by allowing only one individual per institution to recommend candidates, thus to accept only one nomination per institution. To decrease the number of reviews it is suggested that the jury is briefed to better make use of the possibility of creating shortlists.

- As the jury is the same for the START programme and the Wittgenstein Award, the suggestion to introduce a rotating principle for the members of the international jury holds also for this programme.

- Communication of the achievements: the achievements of the research with the Wittgenstein funding could be better communicated to the wider public. This is especially valid for aspects beyond the individual achievements of the awardee. In this sense, the beneficial effects of the Wittgenstein group on the promotion of young researchers and group members could be emphasized more strongly. Moreover, the leading role of the Wittgenstein groups in specific research disciplines could be put into spotlight.

- Public awareness: The Wittgenstein Award in general and the award ceremony in particular gains media attention and contributes to the visibility of the awardees. This 
can contribute to raise public awareness for basic research and for the top performances of Austrian researchers. Nevertheless, its potential for the communication of research - an objective of the FWF - is far from being fully exploited. Some awardees are very active in this context, e.g. with view to increase interest of young people for research, to explain their research areas to a broader public or to comment on topics of actuality, others seem not very committed to PR activities. For the moment, the activities are set mainly on individual level. Initiatives to use the group potential of the Wittgenstein Award winners, such as the Wittgenstein Club or the Wittgenstein Academy, have not yet the desired visibility and attention. Measures to enhance the commitment of Wittgenstein Award winners to PR activities are to be discussed as well as further support in this respect for already existing initiatives (Wittgenstein Club and Wittgenstein Academy). 


\section{DOI \& Data Sheet}

\begin{tabular}{|c|c|}
\hline Title & Evaluation of the START Programme and the Wittgenstein Award \\
\hline Authors & Sarah Seus(1), Eva Heckl(2), Susanne Bührer(1) \\
\hline Corresponding Author & Sarah Seus \\
\hline Author affiliations & $\begin{array}{l}\text { (1) Fraunhofer Institut für System- und Innovationsforschung; (2) } \\
\text { KMU Forschung Austria }\end{array}$ \\
\hline DOI & $10.5281 /$ zenodo.50610 \\
\hline Publishing Date & April 2016 \\
\hline Publication Type & Evaluation; Report \\
\hline Publication Venue & Karlsruhe, Wien \\
\hline Peer Review & no \\
\hline Subject Areas & Science Policy; Research Policy; Programme Evaluation \\
\hline Keywords & $\begin{array}{l}\text { START programme, Wittgenstein prize, programme evaluation, sci- } \\
\text { entific careers, scientific performance, Austrian Research System }\end{array}$ \\
\hline Pages & $\begin{array}{l}\text { Final Report: } 102 \text { Pages } \\
\text { Annexes: } 91 \text { Pages }\end{array}$ \\
\hline Copyright & @ 2016 [Sarah Seus, Eva Heckl, Susanne Bührer] \\
\hline Licence & $\begin{array}{l}\text { This is an open access publication distributed under the terms of the } \\
\text { Creative Commons Attribution } 4.0 \text { International (CC BY } 4.0 \text { ) which } \\
\text { permits unrestricted use, distribution, reproduction and adaptation in } \\
\text { any medium and for any purpose provided that it is properly attrib- } \\
\text { uted. For attribution, the original author(s), title, publication source } \\
\text { and either DOI or URL of the article must be cited. }\end{array}$ \\
\hline Cite as & $\begin{array}{l}\text { Seus, Sarah, Heckl, Eva, Bührer, Susanne (2016). Evaluation of the } \\
\text { START Programme and the Wittgenstein Award. Final Report. } \\
\text { Seus, Sarah, Heckl, Eva, Gruber, Sonia (2016): Evaluation of the } \\
\text { START Programme and the Wittgenstein Award. Annexes. }\end{array}$ \\
\hline Data Availability & $\mathrm{n} / \mathrm{a}$ \\
\hline Competing Interests & $\mathrm{n} / \mathrm{a}$ \\
\hline Funding & FWF \\
\hline Author Contributions & $\begin{array}{l}\text { The publication is a joint effort of all authors mentioned whereas } \\
\text { Sarah Seus and Susanne Bührer (Fraunhofer ISI) focussed on the } \\
\text { START programme and Eva Heckl (KMU Forschung Austria) on the } \\
\text { Wittgenstein Prize. }\end{array}$ \\
\hline Acknowledgements & $\begin{array}{l}\text { with the participation of Niclas Meyer, Sonia Gruber, Tobias Burst, } \\
\text { Christina Schmedes and Barbara Sinnemann }\end{array}$ \\
\hline
\end{tabular}

